$10-2000$

\title{
Assessing the New Judicial Minimalism
}

Christopher J. Peters

University of Baltimore School of Law, cpeters@ubalt.edu

Follow this and additional works at: http://scholarworks.law.ubalt.edu/all_fac

Part of the Constitutional Law Commons, Judges Commons, Jurisprudence Commons, and the Supreme Court of the United States Commons

\section{Recommended Citation}

Assessing the New Judicial Minimalism, 100 Colum. L. Rev. 1454 (2000)

This Article is brought to you for free and open access by the Faculty Scholarship at ScholarWorks@University of Baltimore School of Law. It has been accepted for inclusion in All Faculty Scholarship by an authorized administrator of ScholarWorks@University of Baltimore School of Law. For more information, please contact snolan@ubalt.edu. 


\title{
ASSESSING THE NEW JUDICIAL MINIMALISM
}

\author{
Christopher J. Peters*
}

The author critiques recently prominent arguments for "judicial minimalism" in constitutional decisionmaking. Current minimalist arguments, the author contends, are primarily "policentric," that is, focused on the role the judiciary can play in bolstering the accountability and deliberativeness of the political branches. Drawing in part on a previous article, the author offers an alternative approach to minimalism that is "juricentric"focused on the inherent democratic legitimacy of the adjudicative process and the unique competence of that process to produce decisions about individual rights. He argues that a juricentric approach supports what he calls "procedural" minimalism: the practice of presumptively deciding constitutional cases in the "narrowest" and "shallowest" way possible. He also argues, however, that a juricentric approach undermines the case for "substantive" minimalism: the practice of presumptively deferring to the political branches in deciding the issues necessary to resolve constitutional cases.

To choose ways of not acting was ever the concern and scruple of my life. - Bernardo Soares ${ }^{1}$

\section{INTRODUCTION}

Much of the way we think about the institution of judicial review, and about its uneasy place in the American constitutional democracy, can be laid squarely at the feet of two brilliant men who happened to share the same first name. Alexander Hamilton, in The Federalist No. 78, famously began his defense of judicial review by dismissing the judiciary as the "least dangerous". branch. ${ }^{2}$ Nearly as famously, Alexander Bickel took Hamilton's description as the title of his germinal 1962 book about judicial review. ${ }^{3}$ Hamilton may have believed in the infirmity of the judiciary, but Bickel assuredly did not; his title was intentionally ironic, and his book was an entreaty and a justification for judicial self-control in a world that the Supreme Court, with Brown $v$. Board of Education, had recently proven its ability to change dramatically with a stroke of the pen. ${ }^{4}$

* Assistant Professor of Law, Wayne State University Law School. I thank Michael Dorf, Richard Fallon, and Cass Sunstein for their comments on earlier drafts; Michelle Chaudhuri and Douglas Salzenstein for their excellent research assistance; Dean Joan Mahoney and Dean Emeritus James Robinson for summer research funding; and, as always, my wife Trish Webster for her unflagging support.

1. José Saramago, The Year of the Death of Ricardo Reis, at v (Giovanni Pontiero trans., Harcourt Brace Jovanovich, Inc. 1991) (1984) (quoting Fernando Pessoa, Livro do desassossego [The Book of Disquiet] (Maria Aliete Galhoz \& Teresa Sobral Cunha eds., Atica 1982) (composed ca. 1913-1935)).

2. The Federalist No. 78, at 437 (Alexander Hamilton) (Isaac Kramnick ed., 1987). (1962).

3. Alexander M. Bickel, The Least Dangerous Branch (Yale Univ. Press 2d ed. 1986)

4. 347 U.S. 483 (1954). The extent to which the Court has succeeded in changing society, in the school desegregation context and others, is hotly debated. See, e.g., Gerald 
Today virtually no one shares Hamilton's professed confidence "that the judiciary is beyond comparison the weakest of the three departments of power"-so weak that "it can never attack with success either of the other two."5 During the latter half of the twentieth century, however, most of the consternation over judicial review came from the right side of the political spectrum. ${ }^{6}$ With the changing winds of political fortune showing their effects on the Supreme Court, this is no longer true. Two stalwarts of the Critical Legal Studies movement, Mark Tushnet and Duncan Kennedy, have recently published books assailing judicial review. ${ }^{7}$ And from more traditionally liberal quarters has come a call, led by Cass Sunstein, for something Sunstein labels "judicial minimalism""a distinctive form of judicial decision-making" by which a court "settles the case before it, but leaves many things undecided." ${ }^{8}$ Sunstein's plea

Rosenberg, The Hollow Hope 336-43 (1991) (concluding that litigation rarely succeeds in producing lasting social change); Mark A. Graber, Law and Sports Officiating: A Misunderstood and Justly Neglected Relationship, 16 Const. Commentary 293, 307-10 (1999) (describing the research of Rosenberg and other social scientists into the relationship between court decisions and social change).

5. The Federalist No. 78, supra note 2, at 437.

6. See, e.g., Robert H. Bork, The Tempting of America 187-93 (1990) (arguing that judicial review is antidemocratic); Lino A. Graglia, 1n Defense of Judicial Restraint, in Supreme Court Activism and Restraint 135, 160-62 (Stephen C. Halpern \& Charles M. Lamb eds., 1982) (arguing that judicial review is a "negation of democracy"); Antonin Scalia, Common-Law Courts in a Civil-Law System: The Role of United States Federal Courts in Interpreting the Constitution and Laws, in A Matter of Interpretation 3, 23-25 (Amy Gutmann ed., 1997) [hereinafter Scalia, Matter of Interpretation] (defending textualism as the only means by which to constrain the discretion of judges).

7. Mark Tushnet, Taking the Constitution Away from the Courts (1999) [hereinafter Tushnet, Taking the Constitution Away]; Duncan Kennedy, A Critique of Adjudication (1997).

8. Cass R. Sunstein, One Case at a Time: Judicial Minimalism on the Supreme Court, at ix (1999) [hereinafter Sunstein, One Case at a Time]. Sunstein also has extensively defended judicial minimalism in a pair of earlier works. See Cass R. Sunstein, Legal Reasoning and Political Conflict (1996) [hereinafter Sunstein, Legal Reasoning]; Cass R. Sunstein, The Supreme Court, 1995 Term-Foreword: Leaving Things Undecided, 110 Harv. L. Rev. 4 (1996) [hereinafter Sunstein, Leaving Things Undecided].

1 hope Professor Sunstein will not take offense at being described as a "traditional liberal." In many ways, as this Article suggests, his views are quite far from traditional. In my opinion, however, Sunstein's stunningly prolific body of work over the past 15 years or so evinces a greater affinity for the liberalism of Locke, the Framers, Mill, and Rawls than for the postmodern skepticism of, say, many adherents of the Critical Legal Studies [CLS] movement. In the free speech context, for example, Sunstein has drawn heavily upon Madison's "high premium on political (not economic) equality," and has rejected "dictation of social outcomes by large, centralized bureaucracies" in favor of more limited "[r]eform of the market." Cass R. Sunstein, Democracy and the Problem of Free Speech, at xvii, xix-xx (1993) [hereinafter Sunstein, Free Speech]. As another example, Sunstein's list of the "substantive core" of minimalism in his most recent book reads like a catalogue of traditional liberal values, including "[p]rotection of political dissent," "[ $t$ ] he right to vote," "[r]eligious liberty," "[p]rotection against physical invasion of property," and "[t]he rule of law." Sunstein, One Case at a Time, supra, at 63-68. At the same time, Sunstein has learned and incorporated many of the more valuable lessons of CLS, such as the impossibility of true "value-neutrality" in government decisionmaking and the complexity 
for minimalism has been influential, prompting a burgeoning responsive literature, ${ }^{9}$ garnering the endorsement of current and former federal judges, ${ }^{10}$ and echoing to some extent in the two Harvard Law Review Su-

of the relationship between government policies and individual preferences. See, e.g., Cass R. Sunstein, The Partial Constitution 1-7, 68-92 (1993) [hereinafter Sunstein, Partial Constitution] (arguing that status quo neutrality mistakes existing distributions for "neutral" situations); id. at 162-94 (arguing that existing preferences often are not fixed but rather are contingent on legal rules and other social factors).

9. A Westlaw search conducted on March 27, 2000, turned up 146 law review articles, essays, reviews, notes, and the like citing Sunstein's 1996 Foreword, not counting four written by Sunstein himself. A cursory review of the items on this list suggests that roughly $20 \%$ directly and extensively engage some aspect of Sunstein's arguments for minimalism. A search conducted on the same date produced 19 law review pieces (not counting Sunstein's own articles) citing Sunstein's 1999 book One Case at a Time, including two full reviews of the book, a brief book note, and a fairly extensive treatment in Jeffrey Rosen's Foreword to the Michigan Law Review's 1999 Book Survey issue, in which Rosen argues that Sunstein undervalues the importance of principled decisionmaking by the Supreme Court. See Jeffrey Rosen, Foreword, 97 Mich. L. Rev. 1323 (1999). I discuss one particularly interesting review of Sunstein's book, written by Neal Devins, in Part 1.B.3.b, infra. The only other full review of the book published in a law review generally praises it but argues for the importance of deep moral reasoning in Court opinions. See Paul J. Weithman, Book Review, 26 J.C. \& U.L. 379 (1999). The book note is one paragraph long and entirely descriptive. See Book Note, 24 Law \& Soc. Inquiry 774 (1999).

10. Richard Posner, Chief Judge of the Seventh Circuit, has declared, "I like Sunstein's [minimalist] approach," which "is close to my own preferred stance, which I call "pragmatic." Richard A. Posner, Against Constitutional Theory, 73 N.Y.U. L. Rev. 1, 9 (1998). Abner Mikva, formerly Chief Judge of the D.C. Circuit, has written that he is "most pleased that Professor Cass Sunstein has brought Bickel's ideas back into play with his advocacy of judicial minimalism." Abner J. Mikva, Why Judges Should Not Be Advicegivers: A Response to Professor Neal Katyal, 50 Stan. L. Rev. 1825, 1825 (1998). Judge Mikva also provided one of the dust-jacket squibs for One Case at a Time.

But has Sunstein's minimalism been influential in judicial opinions? A Westlaw search of the ALLFEDS database conducted on March 27, 2000, produced seven federal opinions citing Sunstein's Foreword. Of these, four expressly relied upon (their interpretations of Sunstein's notion of minimalism as a basis for avoiding constitutional issues, although only one of these four was a majority opinion. See Maine Green Party v. Maine, 173 F.3d 1, 5 (1st Cir. 1999) (citing minimalism as a reason to enforce waiver of an argument not made before a magistrate judge); Equality Found. v. City of Cincinnati, 75 Fair Empl. Prac. Cas. (BNA) 1763, 1764 (6th Cir. 1998) (Boggs, J., concurring in denial of rehearing en banc) (citing Sunstein's description of the "minimalist" Court decision in Romer v. Evans, 517 U.S. 620 (1996), as support for denying rehearing in a case upholding a Cincinnati ordinance similar to the provision at issue in Romer); Women's Med. Profl Corp. v. Voinovich, 130 F.3d 187, 211-12 (6th Cir. 1997) (Boggs, J., dissenting) (criticizing the majority on minimalist grounds for unnecessarily invalidating provisions of an Ohio abortion law); Causeway Med. Suite v. Ieyoub, 109 F.3d 1096, 1121 (5th Cir. 1997) (Garza, J., concurring) (grudgingly following the Supreme Court's abortion precedents but criticizing them on minimalist grounds for "centralizing and constitutionalizing the most controversial issues of public policy"). One district court opinion acknowledged Sunstein's minimalist concern for "cautio[n] in applying traditional concepts" to new technology (the Internet in that case) but nonetheless subjected the defendant to personal jurisdiction in Massachusetts based on traditional "minimum contacts" analysis. Digital Equip. Corp. v. Altavista Tech., Inc., 960 F. Supp. 456, 462-63 (D. Mass. 1997). The remaining two opinions simply cited Sunstein's doctrinal analysis of Supreme Court decisions without discussions of minimalism per se. See Milner v. Apfel, 148 F.3d 812, 816 (7th Cir. 1998) 
preme Court Forewords that followed Sunstein's initial articulation of minimalism. ${ }^{11}$

This new judicial minimalism ${ }^{12}$ hearkens, self-consciously and often somewhat defensively, back to the original minimalist manifesto, Bickel's The Least Dangerous Branch. But it has key points of difference with Bickel. Most important among these differences for my purposes here is the new emphasis on judicial minimalism less as a means of preserving the legitimacy and efficacy of the judiciary and more as a means of bolstering those qualities in the other two branches. While Bickel's project might be described as juricentric-it counseled minimalism chiefly as a method of protecting the judiciary's own place in the constitutional system-the projects of Sunstein and the other new minimalists are, if you will, policentric $^{13}$ - they defend minimalism almost solely as a way of deferring to and bolstering the legitimacy and efficacy of the political branches. Turning Hamilton's defense of judicial review on its head, the new minimalists seek not ways to "defend [the judiciary] against [the other branches'] attacks," 14 but rather ways to defend the other branches against attacks by the judiciary.

This Article is a partial assessment of the validity of this new call for judicial minimalism. The partial nature of my analysis lies chiefly in the fact that 1 will not pursue one obvious (but to me not so interesting) avenue of attack on the new minimalism: its potential threat to predictability, stability, equality of treatment, ${ }^{15}$ and other "rule of law" values. There is already a substantial body of literature debating the relative utilitarian merits of broad judicial rulemaking versus case-by-case, gradualist

(Posner, C.J.) (citing Sunstein's analysis of Romer); Hutchins v. District of Columbia, 144 F.3d 798, 813 n.22 (D.C. Cir. 1998) (citing Sunstein's analysis of United States v. Virginia, 518 U.S. 515 (1996)(VMI)), vacated by 156 F.3d 1267 (D.C. Cir. 1998).

11. See Michael C. Dorf, The Supreme Court, 1997 Term-Foreword: The Limits of Socratic Deliberation, 112 Harv. L. Rev. 4, 60-69 (1998); Richard H. Fallon, Jr., The Supreme Court, 1996 Term-Foreword: Implementing the Constitution, 111 Harv. L. Rev. 54, 141-52 (1997).

12. Although the term "judicial minimalism" usually is meant to refer to the practice of courts, 1 use it in my title and throughout the Article to refer also to theoretical defenses of, or entreaties for, the practice of minimalism by courts. That is, I use "judicial minimalism" to mean both a kind of theory about how courts should behave and a way in which courts do or might behave.

13. Not "polycentric," as that term was used by Lon Fuller. Lon L. Fuller, The Forms and Limits of Adjudication, 92 Harv. L. Rev. 353, 394-409 (1978). I discuss Fuller's views on adjudication and their implications for the new minimalism in Part III.C, infra.

14. The Federalist No. 78, supra note 2 , at 437.

15. I have argued elsewhere that equality of treatment for its own sake is not a valid reason for action by judges or other decisionmakers. See Christopher J. Peters, Equality Revisited, 110 Harv. L. Rev. 1210, 1263 \& n.84 (1997); Christopher J. Peters, Adjudication as Representation, 97 Colum. L. Rev. 312, 365 n.182 (1997) [hereinafter Peters, Adjudication]; Christopher J. Peters, Slouching Towards Equality, 84 lowa L. Rev. 801, 805-07 (1999). 
decisionmaking. ${ }^{16}$ Instead, I focus my attention on the justifications offered by Sunstein and others in support of judicial minimalism.

My basic thesis is that the case for the new minimalism fails in crucial respects, because it significantly underestimates both the legitimacy and the competence of the judiciary in making decisions about individual and minority rights. The new minimalism rests mostly on two pillars: the idea that the political branches act with substantially more democratic legitimacy than the Supreme Court, and the idea that the Court is not a substantially better decisionmaker on issues of "principle" or "rights" than the political branches. But, 1 argue, both pillars topple under analysis. The fundamental (but underappreciated) participatory and representative characteristics of adjudicative decisionmaking significantly narrow the legitimacy gap between political and judicial decisions, even in constitutional cases. And other salient features of adjudication-not only its frequently noted insulation from majoritarian politics, but also its relative opacity and its typical gradualism and particularism-make it generally much better at producing decisions about rights than the political branches.

The picture of adjudication that I sketch is one in which the judiciary, and especially the Supreme Court, occupies a central place in the American ideal of deliberative democracy, a place coequal to those taken by the political departments. This view of the Court is, like Bickel's, primarily juricentric, not policentric, and I argue that it undercuts many of the reasons Sunstein and others offer in favor of judicial minimalism. On the juricentric view, minimalism cannot so easily be justified as a means of shifting decisionmaking responsibility to the more accountable political branches, or as a way of reducing the risk and cost of decisionmaking errors. At the same time, the juricentric view suggests different, better reasons for minimalism than those offered by the new minimalists. Minimalism is necessary to preserve the representative accountability, and thus the democratic legitimacy, of adjudication, and to maintain the

16. On the side of broad rules, see, e.g., Larry Alexander, "With Me, lt's All er Nothin'": Formalism in Law and Morality, 66 U. Chi. L. Rev. 530, 532-34 (1999) (arguing that "authoritative rules" allow communities to solve problems of coordination, expertise, and efficiency when abstract moral principles are agreed upon); Antonin Scalia, The Rule of Law as a Law of Rules, 56 U. Chi. L. Rev. 1175, 1176 (1989) [hereinafter Scalia, Law of Rules] (advocating establishment and refinement of broad general rules rather than caseby-case discretion). For arguments generally against broad rules, see, e.g., Sunstein, Legal Reasoning, supra note 8, at 121-35 (noting drawbacks of general rules, including ambiguities, exceptions, over- and underinclusiveness, and procedural injustice). For relatively balanced assessments of the tradeoffs between broad rules and less rule-based decisionmaking regimes, see, e.g., Richard A. Posner, The Problems of Jurisprudence 42-61 (1990) (comparing legitimacy of decisionmaking by rules and by standards); Louis Kaplow, Rules Versus Standards: An Economic Analysis, 42 Duke L.J. 557, 559 (1992) (contrasting the consequences of a standards-based decisionmaking regime with those of a rules-based regime); Kathleen M. Sullivan, The Supreme Court, 1991 Term-Foreword: The Justices of Rules and Standards, 106 Harv. L. Rev. 22, 62-69 (1992) (summarizing arguments for rules and for standards). 
gradualism and particularism that gives the Court its natural advantage in decisionmaking about individual rights.

Thus I argue that the juricentric view generally supports what I call procedural minimalism but not what I call substantive minimalism. Although the line between them is sometimes difficult to draw with precision, procedural minimalism counsels fully and fairly deciding the case before the Court, while limiting the binding impact of that decision as closely as possible to the particular facts of the case. Substantive minimalism, on the other hand, counsels altering or avoiding the decision of the case before the Court out of deference to the political branches. I contend here that, while some degree of procedural minimalism is necessary to preserve the legitimacy and competence of the Court, substantive minimalism generally is not necessary to preserve those features and indeed risks affirmatively undermining them.

This Article proceeds as follows. In Part I, I describe the characteristics and theoretical justification of the new minimalism, focusing especially on Sunstein's leading articulation of it. In Part II, I chip away at the first pillar of the new minimalism: the premise that judicial decisionmaking, particularly in constitutional cases, is inherently less legitimate from the perspective of democracy than political decisionmaking. I argue that this premise is to a large extent erroneous. In Part III, I take aim at the second pillar of the new minimalism: the premise that the judiciary is not significantly better suited than the political branches to make decisions involving individual rights. I suggest that this premise too is mistaken. Together, Parts II and III form the basis of an alternative approach to judicial minimalism that is juricentric rather than policentric.

In Part IV, I explain how the procedural type of judicial minimalism can be justified on a juricentric view of the Supreme Court's role in the American deliberative democracy. Procedural minimalism, I argue, is necessary to maintain the legitimacy and efficacy of Court decisionmaking. In Part V, however, I contend that the juricentric view does not support the substantive type of minimalism-and in fact directly challenges its validity.

\section{The Policentric Case for Judicial Minimalism}

The new judicial minimalism is animated by the twin perceptions that judicial decisionmaking generally is less democratically legitimate, but not less fallible, than decisionmaking by the political branches. The minimalist response to these perceived shortcomings has two potentially contradictory manifestations. First is procedural minimalism, which holds that a court (particularly the Supreme Court) should do what is necessary to resolve a constitutional case, but should avoid issues not necessary to the resolution of that particular case. Second is substantive minimalism, which holds that the Court should presumptively avoid invalidating the government action challenged in a particular constitutional case, whether by upholding the action on the merits or by avoiding decision of 
the constitutional issue. Procedural minimalism is thus about the scope of the Court's decision, regardless of whether that decision invalidates or upholds the legislation at issue in the case. In contrast, substantive minimalism is about the content of the Court's decision-about whether the Court should invalidate legislation or uphold it.

In this Part, I elucidate the perceptions animating the new minimalism, and the procedural and substantive consequences of those perceptions, by describing several examples of new minimalist theory. I focus especially on the ideas of Sunstein, the leading figure of the new minimalism.

\section{A. Narrowness, Shallowness, and Democratic Deliberation: Sunstein's Judicial Minimalism}

Sunstein's recent book One Case at a Time is the most comprehensive statement yet of new minimalist ideas. One Case at a Time draws upon arguments from a number of prior articles and reviews by Sunstein, including his Foreword to the 1996 Harvard Law Review Supreme Court issue, ${ }^{17}$ and makes substantial use of ideas contained in Sunstein's earlier book Legal Reasoning and Political Conflict ${ }^{18}$ and three articles upon which that book was largely based. ${ }^{19}$ Because One Case at a Time incorporates and expands arguments offered in Sunstein's previous writings, I focus here on that book's account of minimalism.

I. Narrowness and Shallowness. - Sunstein divides judicial minimalism into two dimensions: narrowness and shallowness. A court decision is "narrow rather than wide" when it "decide[s] the case at hand" rather than "decid[ing] other cases too." 20 That is, minimalism in its narrowness dimension "tr[ies] to decide cases rather than to set down broad rules." 21 A court decision (really, a court opinion) is "[s]hallow [r]ather than [d] eep" 22 when it reaches a "concrete judgment[ ] on [a] particular case[ ], unaccompanied by abstract accounts about what accounts for [that] judgment[ ]."23 Minimalism in its shallowness dimension thus "tr[ies] to avoid issues of basic principle" in deciding cases. ${ }^{24}$

17. Sunstein, Leaving Things Undecided, supra note 8. Other precursors to One Case at a Time include Cass R. Sunstein, Justice Scalia's Democratic Formalism, 107 Yale L.J. 529 (1997) (reviewing Scalia, Matter of Interpretation, supra note 6); Cass R. Sunstein, The Right to Die, 106 Yale L.J. 1123 (1997); Cass R. Sunstein, From Theory to Practice, 29 Ariz. St. L.J. 389 (1997); and Cass R. Sunstein, Public Deliberation, Affirmative Action, and the Supreme Court, 84 Cal. L. Rev. 1179 (1996) [hereinafter Sunstein, Public Deliberation].

18. Sunstein, Legal Reasoning, suprá note 8.

19. Cass R. Sunstein, Incompletely Theorized Agreements, 108 Harv. L. Rev. 1733 (1995); Cass R. Sunstein, Problems with Rules, 83 Cal. L. Rev. 953 (1995); Cass R. Sunstein, On Analogical Reasoning, 106 Harv. L. Rev. 741 (1993).

20. Sunstein, One Case at a Time, supra note 8 , at 10 (italics omitted).

21. Id.

22. Id. at 11.

23. Id. at 13 (italics omitted).

24. 1d. at 11. 
Both narrowness and shallowness are manifestations of procedural minimalism, as I define it above. Again, procedural minimalism is the idea that the Court, while fully and fairly deciding the case before it, should nonetheless limit the binding impact of that decision as closely as possible to the particular facts of the case. Minimalism in its narrowness dimension limits the binding impact of a decision in this way by avoiding the articulation of a broad rule that will apply in future similar (but not identical) cases. Minimalism in its shallowness dimension limits the binding impact of a decision by avoiding the articulation of deep principles that might themselves be applied in future similar (but not identical) cases.

2. Deliberative Democracy and the "Minimalist Virtues." - Sunstein contends that there is a "close connection" between the two dimensions of judicial minimalism-narrowness and shallowness-and what he calls "deliberative democracy."25 Sunstein's conception of "deliberative democracy" will be familiar to anyone who has read The Partial Constitution ${ }^{26}$ or Democracy and the Problem of Free Speech, ${ }^{27}$ two of his earlier books; it is professedly Madisonian, emphasizing the role of political representation in fostering deliberation by filtering the often uninformed or ill-considered preferences and viewpoints of the public at large. ${ }^{28}$

As it relates to Sunstein's defense of judicial minimalism, this conception of deliberative democracy has two important aspects. First, it requires a system of political accountability that ties government decisionmak-

25. Id. at 24 .

26. Sunstein, Partial Constitution, supra note 8.

27. Sunstein, Free Speech, supra note 8 . Sunstein aIso has fleshed out his conception of deliberative democracy in many law review articles. See, e.g., Sunstein, Public Deliberation, supra note 17 (contrasting judicial decisionmaking with political deliberation in the area of affirmative action); Cass R. Sunstein, Beyond the Republican Revival, 97 Yale L.J. I539 (1988) (linking deliberative democracy with the traditional claims of republicanism); Cass R. Sunstein, Interest Groups in American Public Law, 38 Stan. L. Rev. 29 (1985) (proposing revival of republicanism as foundation from which judiciary might evaluate political processes and outcomes); Cass R. Sunstein, Naked Preferences and the Constitution, 84 Colum. L. Rev. 1689 (1984) (arguing that the constitutional prohibition of the distribution of resources based on raw political power is the embodiment of deliberative democracy).

28. For example, in One Case at a Time Sunstein writes:

[T] he framers rejected populist models in favor of a republican effort to promote more considered reflection through mechanisms designed, in James Madison's words, to "refine and enlarge" the public view. . . . The American system is one of representative rather than direct democracy, partly because of a judgment that political deliberation can best be promoted through a representative system.

Sunstein, One Case at a Time, supra note 8, at 133; see also Sunstein, Partial Constitution, supra note 8 , at 17-24 (describing background of Founders' establishment of representative, deliberative democracy); Sunstein, Free Speech, supra note 8, at 241-50 (describing importance of representation in fostering true deliberation). Madison's defense of political representation is most famously set out in The Federalist No. 10 (James Madison) (Isaac Kramnick ed., I987). 
ing to the governed, a system that allows for political dissent ${ }^{29}$ and permits equal participation among citizens. ${ }^{30}$ Accountability is important to Sunstein not as a way of effecting the "aggregation of private "preferences" 31 in public policy, but mostly as a way of ensuring that "different information and diverse perspectives" 32 will enter the deliberative process, thus improving the quality of the decisions that process generates.

Second, Sunstein's deliberative democracy requires actual deliberation in political decisionmaking, deliberation based upon reasons that are public-regarding rather than selfish and are rational rather than rooted in revelation or prejudice. Legislation must result only from "a process of reflection and debate," a process in which self-interest, religious beliefs, and "grounds that deny the fundamental equality of human beings" (such as racism) are not accepted as valid reasons for action. ${ }^{33}$

a. Democracy-Permitting Minimalism. - Sunstein argues that judicial minimalism is justified because, and to the extent that, it either permits or promotes accountability or deliberation in the political branches. The connection between judicial minimalism and what Sunstein calls "democracypermitting outcomes" 34 is fairly obvious: A court might permit deliberative democracy to function by "rul[ing] narrowly rather than broadly" or by "declin[ing] to hear a case at all"35 - the ultimate form of minimalismthus leaving ample space in which deliberative democracy can operate. A court also might "simply validate what democratic processes have produced." 36

According to Sunstein, democracy-permitting minimalism of this type has five categories of "virtues."37 First, it typically lowers decision costs by allowing the Court to avoid full resolution of complex problems. ${ }^{38}$ Second, it typically lowers error costs-"the costs of mistaken judgments"39_by limiting as much as possible the scope of the Court's judgments and thus their impact if they are erroneous. ${ }^{40}$ Third, it leaves space for "reasonable pluralism" in society by "bracketing the largest disputes" 41 upon which broad agreement is unlikely. ${ }^{42}$ Fourth, it takes account of the "cognitive limitations" faced by judges, including

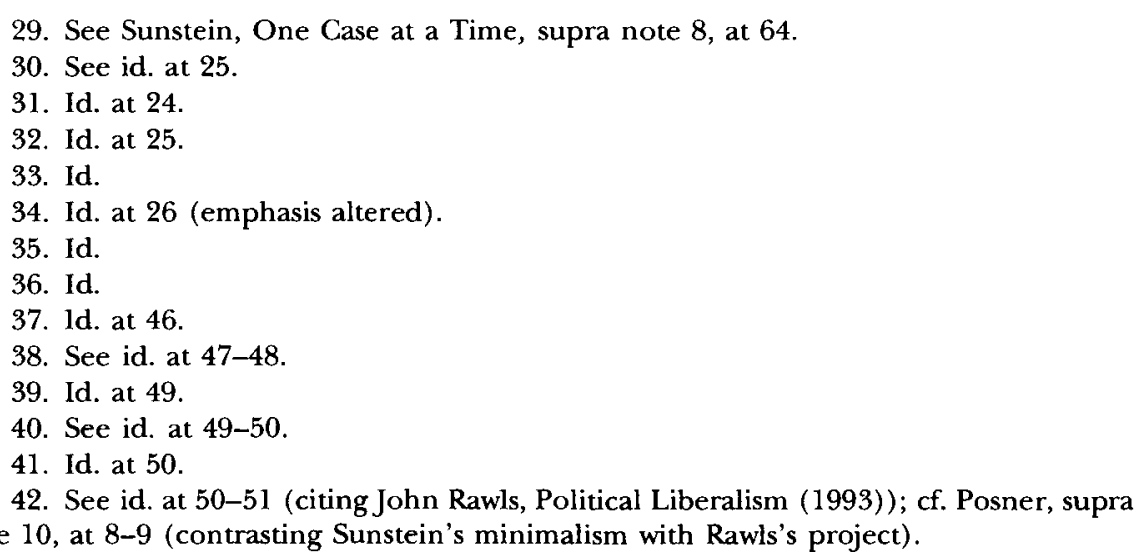


limitations on judges' ability to predict the consequences of their decisions, by avoiding the foreclosure of adjustments and adaptations in future cases. ${ }^{43}$ And fifth, it "allows democratic processes room to maneuver," 44 a desirable effect in light of judicial fallibility and the possibility that even otherwise correct judicial decisions will be counterproductive. ${ }^{45}$

On Sunstein's view, judicial minimalism can serve all of these values by simply allowing the political process to function unimpeded by interference from the Court. Such democracy-permitting minimalism can take either procedural or substantive form. Procedurally, the Court can permit democratic processes to function by limiting its constitutional decisions to the facts of particular cases, thus avoiding foreclosure of democratic judgment in other cases. Substantively, the Court can permit democratic processes to function by declining or avoiding the invalidation of political decisions in the decision of the particular case at hand.

b. Democracy-Promoting Minimalism. - The link between minimalism and democracy-promoting outcomes is more subtle. A "[d]emocracy-promoting outcome[ ]" is one that "attempt[s] to require deliberative judgments by democratically accountable bodies." 46 Such a result does more than simply leave intact the product of democratic deliberation; it affirmatively cultivates deliberative and accountable decisionmaking in the political branches. Indeed, a democracy-promoting result might (and often will) take the form of invalidating decisions made by the political branches, although for reasons that turn on the inadequate deliberation or accountability underlying such decisions rather than on their conflict with more substantive constitutional requirements. Sunstein lists a number of examples of "minimalist" decisions that promote deliberative democracy in this way: invalidation on grounds of vagueness, invalidation pursuant to the nondelegation doctrine, application of "clear statement" principles, invalidation on grounds of desuetude, refusal to consider hypothetical legislative purposes, and enforcement of a requirement that "all decisions [be] supported by public-regarding justifications rather than by power and self-interest." 47

These democracy-promoting forms of decision are procedurally minimalist because they do not go to what might be called the "merits" of the case; they decide particular constitutional cases without holding that the government decision or action at issue in them is, unavoidably and in all similar cases, constitutional or unconstitutional. In other words, like narrow and shallow decisionmaking, democracy-promoting decisions defer until later resolution of the substantive constitutionality of a particular government action when such a resolution is not necessary to decide the case at hand.

43. Sunstein, One Case at a Time, supra note 8 , at 51-53.

44. Id. at 54 .

45. See id. at 53-54.

46. Id. at 26 .

47. Id. at 27 . 
3. Caveats. - Sunstein acknowledges the existence of valid arguments against minimalism in particular circumstances. A minimalist decision in case A may "lead to dramatically increased decision costs for judges in cases B through $\mathrm{Z}$," thus merely "shifting costs from [the precedential] court to others." 48 Minimalism also may actually increase error costs if it turns out that "a minimalist judgment in case A will produce a range of mistakes in cases $B$ through $Z$, as lower court judges struggle to make sense of case A." 49 Minimalism also threatens "rule of law" values like support for planning and the desirability (springing from autonomy concerns) of giving "participants in democratic processes . . . a clear background against which to work." 50 To the extent that minimalist decisions underprotect constitutionally enshrined democratic values like freedom of expression, minimalism might actually weaken deliberative democracy. ${ }^{51}$ And minimalism might be inappropriate in dealing with defects in the democratic process itself, such as the influence of powerful private interest groups or the underrepresentation of historically disadvantaged minorities. ${ }^{52}$

"From these points," Sunstein concedes, "it is clear that we cannot, in the abstract, decide whether and how much minimalism is appropriate." 53 Generally, however, "[t] he case for minimalism is especially strong when the area [of substantive law] involves a highly contentious question now receiving sustained democratic attention." 54

4. Sunstein and Substantive Minimalism. - As described above, Sunstein's theoretical defense of judicial minimalism focuses mainly on procedural minimalism-on techniques of deciding only the necessary issues and no more, such as writing narrow and shallow opinions and deciding cases on democracy-promoting grounds rather than "on the merits." Sunstein's applications of minimalism in particular cases, however, demonstrate that he has substantive minimalism in mind as well-deference to the political branches in the decision (or avoidance) of the necessary issues themselves.

48. Id. at 55 .

49. Id.

50. Id. at 55-56.

51. See id.

52. See id. at 55-56, 275 n.24. Sunstein here draws upon the well-known theory of "representation reinforcement" articulated by John Hart Ely. See John Hart Ely, Democracy and Distrust (1980). One Case at a Time is perhaps the closest Sunstein has yet come in print to an endorsement of Ely's theory of judicial review. Cf. Rebecca L. Brown, Accountability, Liberty, and the Constitution, 98 Colum. L. Rev. 531, 539 n.27 (1998) (“1 think it is time to add Cass Sunstein's name to the list of those whose starting point for constitutional rights is the integrity of the political process.").

53. Sunstein, One Case at a Time, supra note 8 , at 56.

54. 1d. at 59 . 
For example, Sunstein defends the Supreme Court's decisions in Washington v. Glucksberg 55 and Vacco v. Quill, ${ }^{56}$ in which the Court upheld two state laws forhidding physician-assisted suicide against, respectively, due process and equal protection challenges, partly on the ground that "the Court should be wary of recognizing rights of this kind amid complex issues of fact and value." 57 This is substantive minimalism. Procedural minimalism would counsel not reluctance to recognize a right to assisted suicide, but rather the recognition or rejection of the right in a way that is confined as closely as possible to the facts of the particular case being decided.

Similarly, while Sunstein praises the Court's constitutional affirmative action jurisprudence on the basis of its "meandering course" and "refusal to issue rules" (that is, its characteristic narrowness), he also suggests that ultimately "the issue of affirmative action should be settled democratically, not judicially." 58 Apparently Sunstein means that the Court, out of deference to the political branches, should avoid recognizing rights against affirmative action. Likewise, Sunstein defends four recent Court decisions involving the interaction between "new communications technologies" 59 and the First Amendment ${ }^{60}$ partly on the procedural grounds of narrowness but also partly because the presence of factual and moral "flux" in this area "argnes in favor of judicial caution in invalidating regulatory controls" 61 -in favor, that is, of substantive minimalism, of a reluctance by the Court to overturn political judgments even on the narrow facts of a particular case. ${ }^{62}$

Although Sunstein's theoretical case for judicial minimalism centers on the avoidance of broad rules and deep theory in the Court's constitutional decisionmaking-that is, on the formal or procedural aspects of Court decisions-his applications of that theory thus frequently suggest an additional focus on the content or substance of Court decisions-that is, on whether the Court is invalidating or upholding actions of the political branches. For reasons that will become apparent in Parts 11 and III, this expansion of focus is not surprising. The same policentric assumptions of judicial illegitimacy and inefficacy that underlie Sunstein's procedural minimalism also underlie his substantive minimalism. As such, if the Court is significantly less legitimate and not significantly more effective

55. 521 U.S. 702 (1997).

56. 521 U.S. 793 (1997).

57. Sunstein, One Case at a Time, supra note 8 , at 76 .

58. 1d. at $117-18$

59. Id. at 173 .

60. See Reno v. ACLU, 521 U.S. 844 (1997); Turner Broad. Sys., lnc. v. FCC, 520 U.S 180 (1997) (Tumer II); Denver Area Educ. Telecomms. Consortium, 1nc. v. FCC, 518 U.S. 727 (1996); Turner Broad. Sys., Inc. v. FCC, 512 U.S. 622 (1994) (Turner $I$ ).

61. Sunstein, One Case at a Time, supra note 8 , at 174 .

62. I explain below how a procedurally minimalist approach might properly take into account considerations of moral and factual "flux." See infra notes 261-262 and accompanying text. 
than the political branches in making decisions about rights, then the Court should observe not only a procedural presumption against broad rules and deep theory, but also a substantive presumption against overturning the decisions of the political branches.

5. Sunstein and Bickel. - It may be helpful to conclude this overview of Sunstein's argument for minimalism, and to set the stage for my critique of that argument and related arguments in Parts II, III, and V, by noting the obvious comparison between Sunstein's minimalism and the "passive virtues" Alexander Bickel promoted in The Least Dangerous Branch. Sunstein pays express homage to Bickel, ${ }^{63}$ but he also goes to some length to describe the "important differences" between Bickel's project and his own. ${ }^{64}$ The primary difference, Sunstein asserts, lies in the divergent assumptions of political theory underlying the two projects:

My argument here finds its foundations in the aspiration to deliberative democracy, with an insistence that the principal vehicle is the legislature, not the judiciary .... For Bickel, the Court was the basic repository of principle in American government; because of its insulation, it was the central deliberative institution. By contrast, a central point here is that the Court's conception of the (constitutionally relevant) principle may well be wrong; I think Bickel erred in seeing the Court as having a systematically better understanding of "principle" than other branches. ${ }^{65}$

Sunstein thus distinguishes his project from Bickel's primarily on the ground that Bickel's was what I have called juricentric-focusing on preserving the Court's own place in the constitutional system-while Sunstein's is what I have called policentric-emphasizing the relationship between judicial minimalism and deliberative democracy within the political branches. As I explain below, my basic challenge to the new minimalism as conceived by Sunstein and others focuses on this policentrism. I contend that the new minimalism is somewhat myopic, not only in undervaluing the Court's role as the deliberative crucible of principle in our constitutional democracy, but also in ignoring the sense in which the Court is itself fundamentally democratic.

\section{B. Other Proponents of the New Minimalism}

Sunstein's first comprehensive justification of judicial minimalism appeared in his Foreword to the Harvard Law Review's 1996 Supreme Court issue. ${ }^{66}$ Each of the two succeeding Harvard Forewords also con-

63. See Sunstein, One Case at a Time, supra note 8 , at 5, 39-41, 100, 267 n.5; see also Sunstein, Leaving Things Undecided, supra note 8 , at 51-53.

64. Sunstein, One Case at a Time, supra note 8 , at 267 n.5.

65. Id.

66. See Sunstein, Leaving Things Undecided, supra note 8. Although Sunstein's Foreword was published in 1996, the issue containing it retrospectively covered the Court's 1995 Term. The years I give in the text for the Harvard Forewords refer to their years of publication rather than the years of the Supreme Court terms that they cover. 
tained significant strains of minimalism, although neither of them can accurately be described as minimalist in nearly as thoroughgoing a way as Sunstein's work. I discuss them here, and then briefly survey the work of some other recent proponents of judicial minimalism and related approaches.

1. Richard Fallon. - In his 1997 Harvard Law Review Foreword, ${ }^{67}$ Richard Fallon describes and defends, partly on minimalist grounds, the Court's use of doctrinal tests in constitutional cases. Fallon articulates two minimalist justifications for doctrinal tests. First, doctrinal tests allow the Court to avoid deeply theorized grounds for its judgments; they "abet [ ] incompletely theorized judgments by furnishing a framework in which determinations can be reached and ... explained as defensible within the doctrinal framework, even if the framework is not itself justified by any broader theory." 68

Second, the Court's preference for certain types of doctrinal testswhat Fallon calls "suspect-content" and "nonsuspect-content" tests ${ }^{69}$-allows the Court to defer to the political branches "except in circumstances in which the democratic process is manifestly untrustworthy." ${ }^{70}$ Suspectcontent tests include strict scrutiny, under the Equal Protection and Due Process Clauses, of legislation that burdens suspect classes or infringes fundamental rights; ${ }^{71}$ nonsuspect-content tests include rational basis review of other legislation under those clauses. ${ }^{72}$ Fallon contends that nonsuspect-content tests, which are extremely deferential to the political branches, are appropriately applied in areas of constitutional law characterized by "reasonable disagreement" about the existence and scope of a constitutional norm. ${ }^{73}$ Where reasonable disagreement exists, "the basic commitment of the Constitution is to permit decision by democratic majorities and their elected representatives." 74

Fallon clearly is not as minimalist as Sunstein. His defense of doctrinal tests is in an important sense nonminimalist: Such tests really are types of rules that, virtually by definition, apply in cases with facts that are

67. Fallon, supra note 11 .

68. Id. at 116. This argument echoes one made by Sunstein. See, e.g., Sunstein, One Case at a Time, supra note 8, at 11-14 (arguing there are two forms of "incompletely theorized agreements": agreements on particulars with disagreements on the basis of those particulars, and agreements on abstractions with disagreements on how to apply those abstractions to particular cases); Sunstein, Legal Reasoning, supra note 8, at 35-61 (defending "incompletely theorized agreements on particular outcomes" as useful means of facilitating court decisionmaking, accommodating social pluralism, and allowing for change) (quotation at 37).

69. Fallon, supra note 11 , at $68-69$.

70. Id. at 76 .

71. See id. at 88 .

72. See id. at $88-89$.

73. Id. at 89 .

74. Id. Following John Hart Ely, Fallon explains suspect-content tests as a means of allowing court intervention in areas where there is reason to suspect some defect in the political process. See id. at 88-90 (citing Ely, supra note 52, at 75-77, 105-79). 
distinguishable from those of the cases in which the tests originate, and thus they are broader than the case-by-case gradualism that Sunstein advocates. But, like Sunstein, Fallon endorses elements of both procedural and substantive minimalism. Doctrinal tests for Fallon, like analogical reasoning for Sunstein, allow the Court to agree on, and the public to accept, particular results without skirmishing over deeper ideological issues. This is a form of procedural minimalism, extolling as it does the virtues of deciding no more than is necessary to resolve the practical issue before the Court. And Fallon's enthusiasm for deferential nonsuspectcontent tests reflects the view that the Court should yield to the political branches in the face of "reasonable disagreement" about the meaning of the Constitution-a form of substantive minimalism.

2. Michael Dorf. - In his 1998 Harvard Law Review Foreword, Michael Dorf defends a concept of "provisional adjudication" that contains significant elements of both procedural and substantive minimalism. ${ }^{75}$ Dorf proposes that the Court, following a model of provisional adjudication, "worry less about finding the 'true' meaning of authoritative texts, and instead-while sensitive to its own institutional limitations- . . focus on finding provisional, workable solutions to the complex and rapidly changing legal problems of our age."76

The procedurally minimalist aspect of Dorf's "provisional adjudication" would involve a frankly loose, less-precedent-bound version of the common law method, in which the Court would "treat more of its precedents as provisional than is formally permitted under the doctrine of stare decisis," 77 even going so far as to "expressly designate some of its decisions . . . as subject to experiment ... [or] as provisional, promising to revisit these matters at some future date." 78 The substantively minimalist aspect of provisional adjudication would require the Court to "give greater deference to state policies that arguably infringe constitutional rights than to equivalent uniform national policies,"79 and to "permit some doctrinal disagreements among the lower courts to go unresolved in order to discern the practical consequences of different legal regimes." 80

Dorf's version of minimalism is in turns more radical and more traditional than Sunstein's. It is more radical in that Dorf does not share Sunstein's confidence in the common law method, contending that it is too slow to respond to rapidly evolving social conditions ${ }^{81}$ and that it relies too heavily on "intuition[ ] rather than empirical observation" 82 (a weak-

75. Dorf, supra note 11 , at 4 .

76. 1d. at 9 (citations omitted).

77. Id. at 11 .

78. Id. at 73 .

79. Id. at 10 ; see id. at $62-65$.

80. Id. at I0-11; see id. at 65-66.

81. See id. at $43-45,53$.

82. Id. at 36 . 
ness Dorf claims the common law shares with, and perhaps partly derives from, the so-called Socratic method of legal instruction ${ }^{83}$ ). It is more traditional in that it ultimately proposes a role for the Court that is in significant respects nonminimalist, a role in which the Court's "central task" is "the articulation of fundamental . . . values," leaving the implementation of those values mostly to the political process. ${ }^{84}$ This proposal is nonminimalist in its call for the Court to pronounce values that are broad and deeply theorized; it is substantively minimalist in its suggestion of deference to the political branches in questions of ground-level application of those values.

3. Other New Minimalists, and Some Cousins. - Like all intellectual movements, the new minimalism is fairly clear at the center but a bit fuzzy around the edges. Sunstein's scholarship of minimalism is the most extensive of anyone's since Bickel's, and mostly for that reason I think it is fair to treat him as a sort of exemplar or paradigm of the new minimalist. My selection of Fallon and Dorf for particular attention here is largely the product of using Sunstein's work as a template; the contribution of each of those scholars, as I suggested above, has important similarities to that of Sunstein, despite also displaying some significant differences. Fallon's and Dorf's contributions also merit special attention because of the forum in which they appeared: the widely read Forewords to the Harvard Law Review's annual Supreme Court issue.

Let me describe now, briefly and roughly, the two characteristics that I take to be at the core of the new minimalism, as exemplified by its three proponents discussed above. First, the new minimalism displays both substantive and procedural aspects. It advocates sometimes rendering narrow and/or shallow decisions of squarely presented issues (procedural minimalism), and sometimes avoiding decisions of squarely presented issues altogether or deciding them in a way that upholds decisions of the political branches (substantive minimalism). The exact balance of these types of minimalism depends upon the particular theory.

Second, the new minimalism is animated to a significant extent by some combination of two premises: the premise that decisionmaking about an issue generally is less democratically legitimate when done by a court than when done by one of the political branches, and the premise that courts generally are no more competent at making decisions about constitutional rights than the political branches are. I discuss both of these premises in more detail in Part I.C, below, and then attack each of them respectively in Parts II and III. Again, the exact proportion in

83. See id. at $33-43$.

84. Id. at 79. The details of Dorf's proposal that the Court should mostly confine itself to the articulation of rather abstract values, leaving questions of implementation to political decisionmakers, are spelled out in Michael C. Dorf \& Charles F. Sabel, A Constitution of Democratic Experimentalism, 98 Colum. L. Rev. 267, 388-404, 444-69 (1998). 
which these two premises motivate minimalist thinking depends on the particular minimalist theory.

My purpose for articulating these core characteristics of the new minimalism is to introduce briefly some other examples of it or of its close cousins. Most of my arguments against substantive minimalism in the remainder of this Article will apply to these other examples as well as to the work of Sunstein, Fallon, and Dorf, although the extent and strength of their application will vary from example to example.

I begin with a discussion of the work of Robert Burt, which is in many ways an immediate precursor to the new minimalism but in some crucial ways a very different animal. I then briefly discuss the "discursivist" versions of minimalism espoused by Neal Devins and Neal Kumar Katyal. Finally, I consider the recent argument for the outright abolition of judicial review advanced by Mark Tushnet.

a. Robert Burt. - Robert Burt might be considered a progenitor of the new judicial minimalism. His 1992 book The Constitution in Conflict is an ambitious and challenging work in which Burt defends "an egalitarian conception of authority among the branches" in constitutional interpretation. ${ }^{85}$ Burt advocates the use of many of the techniques of judicial minimalism espoused earlier by Bickel and later by Sunstein, including invocation of "clear statement" principles and of the doctrines of "void for vagueness" and ripeness. ${ }^{86}$ Burt also identifies and endorses the use of "middle-tier" constitutional scrutiny as what Sunstein would call a "democracy-promoting" minimalist technique, helpful in spurring deliberation in the political branches. ${ }^{87}$

But unlike Sunstein and, to a lesser extent, Dorf and Fallon, Burt is decidedly distrustful of the political process. His version of judicial minimalism is inspired not by a preference for political over judicial decisionmaking, but by a conception of democracy as the absence of coercion. For Burt, coercion is antidemocratic, whether its source is the Supreme Court or an overreaching political majority. Thus Burt endorses judicial minimalism not simply to give pride of place to the political process, but rather to avoid or mitigate judicial coercion of the losing side in a constitutional conflict. At the same time, Burt supports frequent "par-

85. Robert A. Burt, The Constitution in Conflict 5 (1992).

86. Id. at 359-60, 360-61, 361-62. Sunstein expressly acknowledges his debt to Burt in One Case at a Time. See Sunstein, One Case at a Time, supra note 8, at 268 n.5.

87. Burt, supra note 85 , at 363 ; see also id. at $362-67$. "[M] id-level scrutiny is an important jurisprudential innovation that holds considerable promise in many different contexts. lts great virtue . . . is its conversational character: when the Court invalidates a statute on this basis, this action permits and even invites a legislative response." ld. at 364; cf. Sunstein, One Case at a Time, supra note 8, at 163-70 (praising Court's VMI decision for invalidating discrimination apparently motivated by animus towards women while leaving the legislature free to pursue gender segregation in appropriate contexts); Jay D. Wexler, Defending the Middle Way: Intermediate Scrutiny as Judicial Minimalism, 66 Geo. Wash. L. Rev. 298, 303 (1998) (offering another minimalist defense of "middle-tier" or "intermediate" scrutiny). 
ticularistic, contextually circumscribed, tentatively offered judicial interventions" ${ }^{\prime 88}$ as necessary to prevent one side in such a conflict from coercing the other. ${ }^{89}$

lt is a bit difficult to separate the substantive from the procedural implications of Burt's approach... Procedurally, Burt advocates (and criticizes the Court for failing to render) narrow decisions on controversial constitutional issues like the death penalty ${ }^{90}$ and abortion, ${ }^{91}$ lamenting the Court's abandonment of "small-gauge rulings" in the former context $\mathrm{t}^{92}$ and its disregard of narrower void-for-vagueness or equal-protection grounds of decision in the latter. ${ }^{93}$ Substantively, Burt sometimes appears to advocate complete judicial abstention from decision of such issues, as when he suggests that the Court might have used the doctrine of ripeness to decline adjudication of the abortion controversy. ${ }^{94}$ The difficulty is that Burt's approach does not lend itself comfortably to categorization into "substantive" and "procedural" aspects, because Burt's underlying point is essentially that no institution-not the judiciary, and not a majority within the political branches-should conclusively decide an issue without the agreement of all those affected by the decision. Thus Burt's minimalism is "substantive" in its distaste for judicial invalidation of political judgments, but "procedural" in its support for decisionmaking techniques that decide particular cases while keeping fundamental issues always alive for discussion.

As this brief description suggests, Burt's minimalism is subtly but importantly different from the minimalism of Sunstein, Fallon, and Dorf. It does not seem to be animated by the premise that the Court either is less legitimate or is equally or less competent than the political branches in making decisions about constitutional rights. Burt's minimalism stems instead from a distrust of coercive decisionmaking by any institution, not just the judiciary. In this sense it is less judicial minimalism than minimalism across the board, prescribed for any institution that might make decisions coercing people.

b. "Discursivist" Minimalism. - A recent trend in constitutional scholarship that is closely related to minimalism (and may even be a species of it) is what I will call "discursivism." 95 The core idea of discursivism is that the judiciary, and particularly the Supreme Court, should attempt to resolve constitutional issues by engaging in some form of dialogue or giveand-take with the political branches rather than by imposing final and

88. Burt, supra note 85 , at 367 .

89. See generally id. at 353-75 (advocating or defending minimalistic interventions by the Court in polarized contexts such as school segregation, abortion, and gay rights).

90. See id. at 327-44.

91. See id. at 344-52, 357-62.

92. Id. at 338 .

93. See id. at $348,349-50$.

94. See id. at $360-61$.

95. "Conversationalism" might be a better term, but 1 find it humorously awkward to describe proponents of this approach as "conversationalists." 
authoritative decisions of those issues. The motto of judicial discursivism might well be Neal Devins's statement that "[n]o branch should be the final arbiter of the Constitution's meaning," 96 with the emphasis, as 1 have placed it, on the word "final." On the discursivist view, the Court should decide issues in ways that stimulate rather than foreclose interbranch dialogue and, in doing so, should take advantage of the judiciary's special capacity for the language of principle.

Devins advocates a discursivist approach in his review of Sunstein's One Case at a Time. According to Devins, Sunstein's brand of minimalism "[i]n some ways ... goes too far" and "[i]n other ways ... does not go far enough."97 It goes too far "in discounting the virtues of judicial review, especially with regard to occasions when the judiciary should embrace some interpretive theory of what the Constitution means and thereby play a leadership role in the shaping of constitutional values."98 Sometimes, Devins contends, courts should "invok[e] high-sounding principles when striking down elected government action," 99 because in doing so the judiciary can more persuasively validate other political branch decisions that pass constitutional muster. ${ }^{100}$ More generally, courts should not be afraid to speak in the language of principle-Sunstein's "deep" theorizing-because "their willingness to speak about principle can be salutary, even if the principles they identify are wrongheaded."101 Devins's basic point is that courts can and should contribute meaningfully to the ultimate resolution of contested constitutional issues by injecting the idiom of principle (rather than of self-interest or of cold cost-benefit analysis) into the national discussion, and that this, rather than mere yea-ornay review of political decisions, should be their primary modus operandi. ${ }^{102}$

On the other hand, Devins thinks Sunstein's minimalism "does not go far enough" because it underplays techniques of actually avoiding decision of an issue - the doctrines of "standing [ ] [and] ripeness, certiorari denials, and the like" 103 that Bickel famously referred to as the "passive

96. Neal Devins, The Democracy-Forcing Constitution, 97 Mich. L. Rev. 1971, 1990 (1999) (emphasis added).

97. Id. at 1992.

98. Id.

99. Id. at 1990 .

100. This argument evokes Charles Black's thesis, echoed by Bickel, that the "legitimating function" of judicial review can be just as important as its "checking function." Bickel, supra note 3, at 29-31 (citing Charles L. Black, Jr., The People and the Court $34(1960))$.

101. Devins, supra note 96 , at 1990.

102. Devins's view is partly animated by his belief that, in the long run, the Court's actual decisionmaking means relatively little anyway. See id, at 1991 ("If elected government and the people disagree with the Court, they will countermand its decisionmaking.").

103. 1d. at $1973,1975$. 
virtues." ${ }^{104}$ Here Devins's critique seems primarily one of emphasis, as his arguments for the passive virtues track Sunstein's arguments for substantive minimalism, relying on "[i]nherent limits in judicial factfinding," 105 "the risks of elected government reprisals to unpopular decisionmaking" (with Roe $v$. Wade as the case in point), 106 and the Court's historical lack of success "in hlocking a determined and persistent lawmaking majority on a major policy." 107

Another discursivist is Neal Kumar Katyal, who contends that courts should be unapologetic "advicegivers" with respect to the political branches. ${ }^{108}$ According to Katyal, "[a]dvicegiving occurs when judges recommend, but do not mandate, a particular course of action based on a rule or principle in a judicial case or controversy." 109 Such "advice" is essentially dicta; it is the type of deep theorizing or reasongiving, unnecessary to the strict result of the case, that Sunstein generally ahhors and Devins often admires. For Katyal, the point of judicial advicegiving is to allow courts to avoid the problems of democratic legitimacy and judicial competence that arise when cases are decided hroadly-the standard bugaboos of the judicial minimalists-while at the same time providing some predictability in the law and, crucially, signaling to the political branches potential constitutional problems and potential solutions to them. Katyal writes:

[A]dvicegiving is a natural adaptation in a world in which judges fear deciding issues due to the countermajoritarian difficulty; those jurists who want to avoid interference with legislative power announce narrow holdings, but superimpose broad advice (a form of dicta) by fully explicating the rationale and assumptions behind a decision. ${ }^{110}$

Like Devins, Katyal sees the Court as a coequal participant in the shaping of constitutional understandings. Katyal's judicial advicegiving is akin to Devins's principled leadership; it is the Court's unique method of contributing to a tripartite (judicial, legislative, executive) resolution of constitutional issues. As Katyal explains, "[ $t]$ he Court, hy providing advice, enters into a conversation with the political branches and embraces its partnership."111

Judicial discursivism as espoused by Devins and Katyal has much in common with Sunstein's brand of minimalism, particularly its emphasis on narrow judicial decisionmaking both as a way of respecting the supe-

104. BickeI, supra note 3, at I11; see also supra Part I.A.5 (comparing Sunstein's minimalism with Bickel's "passive virtues").

105. Devins, supra note 96 , at 1978.

106. Id. at 1979.

107. Id. at 1980 (quoting Robert A. Dahl, Decision-Making in a Democracy: The Supreme Court as a National Policy-Maker, 6 J. Pub. Law 279, 286 (I957)).

I08. Neal Kumar Katyal, Judges As Advicegivers, 50 Stan. L. Rev. 1709, 1710 (1998).

109. Id.

110. Id. at 1711 .

111. Id. 
rior democratic legitimacy of the political branches and as a way of avoiding judicial error. 1t parts ways with Sunstein, and to a certain extent with Fallon and Dorf, in advocating deeply reasoned judicial decisions as a way to initiate conversation with the political branches. Here the disagreement seems primarily methodological, as Sunstein favors promoting deliberation through judicial passivity while the discursivists favor promoting deliberation through relatively aggressive, though not necessarily decisive, judicial activity. Discursivism also evokes Robert Burt's emphasis on noncoercion and coequal decisionmaking among the three branches.

Discursivism thus seems mostly to be about procedural minimalism-about deciding actual issues narrowly, with plenty of reasons and dicta thrown in to get the other branches, and perhaps the public, thinking hard about an issue. Devins's version also incorporates substantive minimalism of the type favored by Sunstein, although perhaps to a greater degree. He advocates avoiding some constitutional decisions altogether (and thus at least temporarily deferring to the political branches) in order to reduce the risk of judicial error.

Finally, discursivism introduces a dimension of the debate over judicial review that Sunstein only hints at: the possibility that constitutional issues might be aggressively decided by the Supreme Court but nonetheless left open in some sense for reconsideration by the other branches. This is the possibility of judicial review without judicial supremacy, and 1 discuss it briefly in my treatment of the work of Mark Tushnet in the next section.

c. Abolitionism. - Recently, some on the political left have revived the idea, mostly dormant in respectable circles since the early nineteenth century, that judicial review should be done away with altogether. ${ }^{112}$ This is in a sense the apotheosis of judicial minimalism. Chief among those daring to suggest an end to the "great experiment" 113 of judicial review is Mark Tushnet, and I will focus exclusively and briefly here on his work. Tushnet's latest book, not-so-subtly titled Taking the Constitution Away from the Courts, is a playful and deeply thought-provoking critical examination of the utility and legitimacy of judicial review. Much of Tushnet's argument in the book challenges not judicial review but judicial supremacy: the notion, in its most powerful expression, that the Supreme Court's resolution of a constitutional issue is binding not just on the parties to the particular case decided, but on the political branches of government in every circumstance-litigated case or not-involving the same or an analogous issue, for all time (unless and until the Court changes its mind). ${ }^{114}$ I happen to agree with a large part of Tushnet's argument against judicial

112. This notion, however, has always had some supporters among contemporary political conservatives. See, e.g., Graglia, supra note 6, at 137-42 (arguing for the ultimate form of "judicial restraint": the complete elimination of judicial review).

113. Tushnet, Taking the Constitution Away, supra note 7, at 154.

114. Tushnet challenges judicial supremacy primarily in the first two chapters of his book. See id. at 6-32, 33-53. 
supremacy, for reasons that are well beyond my scope here. A significant portion of Tushnet's book, however, attacks the more modest (and more well-entrenched) institution of judicial review-that is, the authority of courts to refuse to follow (or to "implement," or to "apply") political decisions that they believe to be unconstitutional when those decisions are placed squarely before them in a litigated case. ${ }^{115} \mathrm{lt}$ is of course the institution of judicial review with which judicial minimalism, and thus this Article, is primarily concerned.

Tushnet's attack on judicial review differs significantly from the more moderate critiques offered by the new minimalists-not surprisingly, since Tushnet advocates getting rid of the practice altogether rather than merely reining it in. Part of Tushnet's case-the most interesting part-is unabashedly utilitarian. The Supreme Court, he contends, is now and has been for some time less friendly to "liberal" goals than to "conservative" ones, and thus liberals concerned with good government have ample reason to want to reduce the Court's power. ${ }^{116}$ We can safely put this refreshingly candid argument to one side, for it is well beyond the reach of this Article. ${ }^{117}$

More to the point here is Tushnet's nonpartisan critique of judicial review. Most of this critique is negative-that is, focused not on the affirmative evils of judicial review, but rather on what Tushnet believes to be the general lack of a good reason for having it. Tushnet's primary theme is that the political branches, in the main, are no less capable of making good constitutional decisions than is the judicial branch, ${ }^{118}$ opening the possibility of what Tushnet calls "populist constitutional law."119 Tushnet also believes that judicial review ultimately does not serve the purpose that is usually claimed for it-providing a meaningful check on majoritarian excess-because the Supreme Court typically, if belatedly, tracks the values of the political majority in its decisions. ${ }^{120}$

Tushnet's primary positive critique of judicial review evokes James Bradley Thayer's classic contention that the availability of judicial review renders the political branches less likely to make, and to take seriously, their own constitutional judgments-what Tushnet calls " $t \mathrm{t}] \mathrm{he}$

115. See id. at 129-53, 154-76.

116. This is the primary argument of Chapter Six. See id. at 129-53.

I17. It is, however, worth asking whether Tushnet should be concerned about getting what he wishes for. Should the Court in future years take a turn back to the (comparative) left-as it inevitably will, in my view - then I suppose Tushnet, unapologetically, can write another book, this time entitled Giving the Constitution Back to the Courts.

118. Most of Tushnet's argument for this proposition appears in Chapter Three. See Tushnet, Taking the Constitution Away, supra note 7, at 54-71.

119. Id. at $\mathbf{x}$. See generally id. at 177-94.

120. See id. at 129-53. Tushnet draws empirical support for this assertion primarily from Dahl, supra note 107. See Tushnet, Taking the Constitution Away, supra note 7 , at 216 n.18. 
[i]nfluence of the [j]udicial [o]verhang."121 Tushnet adds several related points which boil down to the claim-which is in some tension with the Thayerian argument-that when the political hranches do pay attention to constitutionality, their fear of judicial review shifts their focus away from good policymaking and toward the production of empty legalese intended to pass the Court's muster. ${ }^{122}$

Tushnet's abolitionist arguments are as substantively minimalist as they come: He advocates universal judicial deference to political judgments in constitutional matters. ${ }^{123}$ Thus most of my arguments against substantive minimalism in Part $\mathrm{V}$ of this Article apply to Tushnet just as they apply to more moderate advocates of minimalism. ${ }^{124}$ But the abolitionist core of Tushnet's arguments, radical as it is in comparison to the relatively modest assertions of Sunstein and other new minimalists, is mostly beyond my scope here.

\section{The Blueprint of a Critique}

The new judicial minimalism espoused by Sunstein, and echoed in key respects by Fallon, Dorf, and others, operates on the premise that decisionmaking by the political branches is generally preferable to decisionmaking by the judiciary. Without this premise, a prescription of judicial minimalism makes no sense; one might as well argue for legislative or executive minimalism. ${ }^{125}$

None of the new minimalists tells us in so many words why a preference for political over judicial decisionmaking is defensible. Let me suggest, however, that such a preference must be based on a two-part calculus. The first part holds that political decisionmaking, generally speaking, is siguificantly more legitimate in a democratic sense than judicial decisionmaking. The second part holds that any supposed advantages of judicial over political decisionmaking, such as a greater ability to protect individual rights, are relatively small or infrequent. These two assumptions combine to form the calculus that underlies new minimalist arguments: In most cases, any advantages of judicial decisionmaking are outweighed by the superior democratic legitimacy of political decisionmaking. Thus the Court should proceed in a minimalist fashion, trumping or preempting the political process only in those relatively rare cases where it is clear

121. Tushnet, Taking the Constitution Away, supra note 7, at 57-58 (citing James Bradley Thayer, The Origin and Scope of the American Doctrine of Constitutional Law, 7 Harv. L. Rev. 129 (1893)).

122. See Tushnet, Taking the Constitution Away, supra note 7 , at 58-65.

123. See, e.g., id. at 175 (proposing the following constitutional amendment: "The provisions of this Constitution shall not be cognizable by any court.").

124. The exception is my argument that substantive minimalism is itself prone to judicial error. See infra Part V.C. This objection should not bother Tushnet, because a Court that never overrides political decisions (as he advocates) cannot commit errors in deciding when and when not to do so.

125. For reasons discussed earlier, Robert Burt's minimalism probably does not share this premise. See supra Part 1.B.3.a. 
that politics surely has got it wrong and that the Court surely will get it right.

In the next two Parts, I suggest reasons to believe that both components of this comparative calculus are wrong, or at least drastically incomplete. First, as I contend in Part II, the assumption that political decisionmaking is, as a general matter, significantly more democratically legitimate than judicial decisionmaking overlooks the fundamentally participatory and representative nature of the adjudicative process. Second, as I argue in Part III, the assumption that courts do not generally possess significantly greater competence than the political branches in the area of individual rights disregards the unique advantages of the adjudicative process for principled deliberation.

\section{Democratic Accountability and the Court}

For Sunstein, the leading new minimalist, a crucial element in the legitimacy of lawmaking within our political system is "accountability." As he explains, in a system of deliherative democracy, "representatives are to be accountable to the public." 126 Accountability, of course, would not be an issue in a direct democracy, in which every citizen participated directly in making laws. ${ }^{127}$ Accountability becomes an issue only in a system of representation, in which some people make decisions in the name of, and with binding effect upon, most of their fellows. And ours is a system of representation; indeed, Sunstein would not have it any other way. Like his political archetype, James Madison, Sunstein believes that true deliberation in a democracy can occur only in representative bodies capable of "refin[ing] and enlarg[ing] the public views."128

And yet Sunstein, like most people, believes the American system is fundamentally democratic, even though most of us do not directly participate in making the laws. Are Sunstein, Madison, and the many others who have been willing to divorce a conception of "democracy" from di-

126. Sunstein, One Case at a Time, supra note 8 , at 24 .

127. This is something of an oversimplification. Even in a direct democracy, the majority might have some obligations of accountability to the minority. This is the impulse that seems to animate the work of Robert Burt and the "representation reinforcement" theory of judicial review made famous by John Hart Ely. See Burt, supra note 85, at 40-41; Ely, supra note 52. But we can put this complex issue to one side for present purposes. At the very least, any problems of accountability are of a very different nature, and probably of a lesser degree, in a system of direct democracy than in a system of representative democracy.

128. The Federalist No. 10, supra note 28, at 126; see also Sunstein, One Case at a Time, supra note 8 , at 133 ("[A] referendum . . . bypasses the ordinary . . . filters of political representation and hence raises special dangers. . . The American system is one of representative rather than direct democracy, partly because of a judgment that political deliberation can be best promoted through a representative system."); Sunstein, Free Speech, supra note 8, at 241-42 (discussing deliberative function of system of political representation); Sunstein, Partial Constitution, supra note 8, at 20-24 (same). 
rect citizen participation in lawmaking somehow missing the point of democracy?

\section{A. Representation and Accountability}

Sunstein and other defenders of representative government-I shall call them "republicans" for simplicity of reference-are not missing the point of democracy. Democracy is about the participation in lawmaking of those governed by the laws. But Sunstein and other republicans believe that the value of participation in representative government can be manifested in other, often better ways besides direct citizen involvement in lawmaking.

The most obvious of these ways is voting. The highest form of political participation for most American citizens is periodically casting a vote in an election. Another obvious form of citizen political participation is political speech, which of course is protected by the First Amendment. ${ }^{129}$

In order to conceptualize representative government as self-government, however, Sunstein, Madison, and other republicans must engage in a little alchemy. They must transform citizen voting and citizen political speech into actual participation in lawmaking, in some recognizable form and to some significant degree. This is where the idea of accountability comes in. Representative government can be thought of as participatory government so long as the representatives-those actually making the laws-are tied sufficiently closely and reliably to the citizens-those bound by the laws. If political representatives are suitably "accountable" to their constituents, then the constituents are in a sense making the laws, even though they are not actually drafting the statutes or regulations, debating them on the legislative floor or in an agency conference room, voting for or against their enactment or promulgation, and so on. The laws can be traced, and attributed, to "the people" in somewhat the same way the actions of an agent can be traced and attributed to the principal. ${ }^{130}$

129. Sunstein is particularly concerned with protecting these forms of political participation. See, e.g., Sunstein, One Case at a Time, supra note 8 , at $64,185-86$ (describing protection of political speecb as part of the substantive "core" of minimalism); id. at 64 (describing the right to vote as part of this core); Sunstein, Free Speech, supra note 8 , at 241-52 (arguing that "the free speech principle should be understood to be centered above all on political thought").

130. But probably not in exactly the same way. The first Congress rejected the inclusion in the Bill of Rights of a "right to instruct" representatives how to vote, to be exercised by a majority of the representatives' constituents. See 1 Annals of Cong. 733-47 (Joseph Gales ed., 1789). Roger Sherman argued against such a right by noting that " $[\mathrm{i}] \mathrm{f}$ [representatives] were to be guided by instructions, there would be no use in deliberation." Id. at 735; see also Sunstein, Free Speech, supra note 8, at 242 (discussing Congress's rejection of "right to instruct"); Sunstein, Partial Constitution, supra note 8, at 22 (same). 
The question then becomes how to ensure suitable accountability from representative to citizen. ${ }^{131}$ ln this regard, "[e]lectoral control is an important part of the system."132 "Electoral control" really has two closely connected elements: electoral coercion and electoral remediation. ${ }^{133}$ Electoral coercion is the mechanism by which elected representatives will avoid wandering too far from the wishes of their constituents for fear of losing their jobs at the next election; ${ }^{134}$ in Madison's words, it is the process by which representatives are "compelled to anticipate the moment when their power is to cease . . unless a faithful discharge of their trust shall have established their title to a renewal of it." ${ }^{135}$ Electoral remediation is the mechanism by which citizens, unhappy with the results of their representatives' efforts, can "throw the bums out" and replace them with new legislators who then can enact better laws.

Electoral control is not the only mechanism of political accountability, however. A process of interest representation plays an important but underappreciated role in the system as well. ${ }^{136}$ When citizens vote for representatives, they are not simply voting for whomever they think most likely to be cowed into defending their interests by the pressure of the polls. (Whether this is who they often get is another matter.) They are voting for someone who they think shares their interests, at least in crucial respects. A representative who shares basic interests of her constituents has a motive to promote those interests quite apart from her desire for reelection, since they are her interests, too, as a private citizen. This is the point Madison was making when he wrote of the "communion of interests and sympathy of sentiments" between representatives and constituents that would be created by the fact that members of Congress "can make no law which will not have its full operation on themselves and their friends, as well as on the great mass of the society."137

The idea of interest representation would seem to be especially helpful to a vision of deliberative democracy like Sunstein's, because it explains how a representative can be both politically accountable and delib-

131. Note the double meaning of "accountability" in this context: In a properly functioning system of representative government, representatives are accountable to the citizens, and-by virtue of this fact-the citizens themselves can be held "accountable" for the laws enacted by their representatives.

132. Sunstein, One Case at a Time, supra note 8, at 24.

133. See Peters, Adjudication, supra note 15 , at 341 .

134. I mean "wishes of their constituents" here in a very ecumenical sense, to allow for theories by which legislators should respond more to their constituents' true "interests," long term goals, and the like, in addition to, or instead of, their day-to-day "wishes." See infra notes 136-140 and accompanying text.

135. The Federalist No. 57, at 344-45 (James Madison) (Isaac Kramnick ed., 1987).

136. See Peters, Adjudication, supra note 15, at 342-46.

137. The Federalist No. 57, supra note 135, at 345; cf. Letter from Edmund Burke to Sir Hercules Langrishe (Jan. 3, 1792), excerpted in Burke's Politics 477, 494 (Ross J.S. Hoffman \& Paul Levack eds., 1949) (explaining desirability of "a communion of interests and a sympathy in feelings and desires" between representative and constituents). 
erative in decisionmaking. ${ }^{138}$ A representative solely concerned with the relatively immediate task of getting reelected might be tempted to trade off her constituents' interests for their shorter-term wishes; she might act as if she were subject to a "right to instruct," even if she thinks the "instructions" she is receiving from her constituents (through public opinion polls, for instance) really will not serve them best in the long run. The result of such an attitude-one all too familiar in modern politics-is a representative's reluctance or refusal to engage in meaningful political discourse, even in the face of facts and arguments to which her constituents are not fully privy.

But a representative who, in representing her constituents' longterm interests, also is representing her own can really deliberate about how best to serve them. She can listen to opposing arguments with an open mind; sbe can evaluate the implications of facts that her constituents do not have; she even can compromise on occasion in the name of a greater good. In deciding how to proceed, the representative can act as her constituents would act, if they had the benefit of the information and arguments available to her. ${ }^{139}$ This is the conception of political decisionmaking that Sunstein favors. ${ }^{140}$ And it is a conception that is, if not impossible without an interest representation component, vastly more convincing with it.

So "accountability" in a deliberative democracy is best conceived of as containing two components: electoral control and interest representation. These components transpose the democratic ideal of citizen participation in lawmaking to the context of representative government. Representative government in turn adds, or at least supplements, the crucial deliberative component of deliberative democracy. Thus the participation of the governed in a deliberative democracy occurs on two basic levels: direct participation, through voting, political speech, and occasionally devices like referenda, initiatives, and New England-style town meetings; and indirect or "virtual" participation, through representatives, by means of a system of political accountability.

138. See Peters, Adjudication, supra note 15, at 345-46.

139. See id. at 345; Joseph M. Bessette, The Mild Voice of Reason 36 (1994) (describing Madison's belief that “[i]f the representatives of the people share the basic interests and desires of their constituents, then their deliberations should result in policies that will approximate what the people themselves would have chosen had they engaged in a similar process of reasoning about the information and arguments presented in national councils"); Hanna Fenichel Pitkin, The Concept of Representation 222 (1967) (quoting New York state legislator as asserting that, " $[\mathrm{h}]$ ad the . . . people who had written me been in the possession of the knowledge which was mine, at least a majority of them would have taken [my] position").

140. See Sunstein, Partial Constitution, supra note 8, at 23 (endorsing the Madisonian view that "[r]epresentatives should not mechanically translate the desires of their constituents into law . . . Even desires, or current beliefs about what courses of action are best, should not be frozen. The framers insisted that existing views might be a product of partial perspectives, of limited experience, or of incomplete information."); see also Sunstein, Free Speech, supra note 8, at 244-48 (making similar points). 


\section{B. Adjudication as Representation}

A fact too often overlooked is that these complementary elementsdirect participation and indirect participation through representationare present not just in decisionmaking by the "political" branches of government, but in adjudication as well. Adjudication, even constitutional adjudication, is driven primarily by the participation of the litigants, not by the court itself. ${ }^{141}$ One of the litigants (usually acting through counsel) initiates the case, by filing a lawsuit or a criminal prosecution. Each litigant locates relevant facts and determines whether and how to present them to the court. Each litigant identifies relevant legal authorities, synthesizes the facts and authorities into legal arguments, and makes those arguments to the court. When the court-meaning the judge, or panel of judges-makes a decision on the merits, or indeed on procedural matters, that decision typically is responsive to the facts presented and arguments made by the litigants. In most courts, dispositive decisions are memorialized and defended by judges in written opinions, largely to ensure precisely this responsiveness.

The role of the judge or judges in all of this remains relatively passive, even under modern rules of procedure and evidence. 1t consists mostly of rendering a decision that is responsive to the proofs and arguments. To the extent the judge's role extends beyond simply deciding the substantive and procedural issues presented in the case by the litigants, it usually is limited to one or more of three kinds of activities: (1) tending to scheduling and other docket-related matters; ${ }^{142}$ (2) narrowing and clarifying the issues that will be contested at trial; ${ }^{143}$ and (3) encouraging settlement. ${ }^{144}$ Moreover, these activities are primarily the province of trial judges, not of appellate panels.

It is thus rather narrowminded to think of adjudication as decisionmaking by judges. Adjudication is decisionmaking by judges and litigants; the boundaries of a judge's or panel's decision are set by the decisions the litigants make with respect to what facts to present, what arguments to

141. The brief description of participatory adjudication that follows derives from my more detailed treatment in Peters, Adjudication, supra note 15, at 347-56, which itself was inspired by a number of sources, primarily Mirjan R. Damaska, The Faces of Justice and State Authority (1986), and Fuller, supra note 13.

142. See, e.g., Civil Justice Reform Act of 1990, 28 U.S.C. $\S \S 471-482$ (1994 \& Supp. IV 1998) (requiring district courts to create and implement "civil justice expense and delay reduction plans"); Fed. R. Civ. P. 16 (giving district judges broad authority to control scheduling of litigation).

143. See, e.g., Fed. R. Civ. P. 16(c) (allowing district judges to "take appropriate action" with respect to, inter alia, "the formulation and simplification of the issues"); Fed. R. Civ. P. 42 (allowing district courts to order consolidation of actions or separate trials).

144. See, e.g., 28 U.S.C. $\$ 473$ (a) (requiring district courts to "consider . . careful and deliberate monitoring" of cases, including "explor[ing] the parties' receptivity to, and the propriety of, settlement"); Fed. R. Civ. P. 16(c)(9) (allowing district judges to encourage "settlement and the use of special procedures to assist in resolving the dispute”). 
make, and how to present and make them. 1t is true, of course, that litigants often complain about judges ignoring what they consider to be important facts or rejecting what they consider to be decisive arguments. Indeed, judges often do this. But judges are subject to criticism when they do this-a point whose significance can hardly be overstated. ${ }^{145}$ Judges do not write their opinions without regard for whether they will be perceived as adequately responsive to what the litigants have done and said. Such considerations surely are foremost in their minds. Nor do judges (for the most part) write opinions in which they make up facts, or rely upon evidence not in the record, or rely upon evidence that they themselves have elicited outside the parties' own efforts, or even, in most cases, rely upon legal arguments not urged by one of the parties. ${ }^{146}$

Sunstein cheapens somewhat these de facto, institutionalized constraints on the judicial role when he classifies judicial reason-giving as a "norm [ ] associated with legal craft."147 Reason-giving is a norm associated with legal (or, more to the point, judicial) craft the way the Hippocratic Oath is a norm associated with medical craft; it is essential to the enterprise. Judicial reason-giving demonstrates whether, and to what degree, a court's decision is responsive to the proofs and arguments presented by the litigants. And responsiveness to the proofs and arguments presented by the litigants is the sine qua non of adjudication. ${ }^{148}$ In this sense, judicial reason-giving is even more vital than reason-giving in the political branches, a norm that Sunstein ranks highly. ${ }^{149}$ Inadequately responsive legislators can be removed from office through the electoral process; inadequately responsive federal judges cannot be. Norms associated with legal craft are all there is to constrain them.

145. And-an equally important point-lower-court judges are subject to reversal on appeal when they ignore important facts or decisive arguments, so long as they have done so in an evident and material enough way. As such, the proclivities of a single nonresponsive judge tend to be rendered less harmful by the discipline of the appellate system.

146. A related point is that judges are siguificantly constrained by the type of arguments the parties usually make: arguments rooted in precedent. As David Strauss has written, "[a] judge who conscientiously tries to follow precedent is significantly limited in what she can do.... Judges wbo might be tempted to overreach, but who are susceptible to criticism . . . , can be evaluated by fairly well developed standards under the common law method." David A. Strauss, Common Law Constitutional Interpretation, 63 U. Chi. L. Rev. $877,926-27$ (1996). As Strauss demonstrates, the constraint imposed upon judges by the common law method operates in constitutional adjudication as well. See id.

147. Sunstein, One Case at a Time, supra note 8 , at 16 . Sunstein's rather dismissive nod toward legal norms in One Case at a Time is anomalous; his book Legal Reasoning and Political Conflict is entirely devoted to the thesis that norms of legal craft play a vital role in the political legitimacy of adjudication. See Sunstein, Legal Reasoning, supra note 8.

148. See Fuller, supra note 13, at 369 ("Adjudication is a process of decision that grants to the affected party a form of participation that consists in the opportunity to present proofs and reasoned arguments.").

149. See, e.g., Sunstein, One Case at a Time, supra note 8, at 24-25, 31 (arguing that "reason-giving" is a central part of legislative and administrative processes); Sunstein, Partial Constitution, supra note 8, at 24-39 (claiming that "the antiauthoritarian impulse, understood as a requirement of reasons, lies at the heart of American constitutional law"). 
Adjudication, then, is a form of government decisionmaking in which those bound by the decision have the opportunity to participate meaningfully-in which the affected parties "are bound by something they helped to make."150 This should sound familiar, because in this sense adjudication incorporates the democratic ideal of self-government. Litigants bound by a court decision have participated in that decision no less integrally-indeed, more integrally-than have most citizens bound by congressional legislation or administrative rulemaking. The synthesizing presence of a judge in adjudication is no more threatening to the fundamentally participatory nature of the process than is the synthesizing presence of representatives to the process of political legislation. Nor is the judge's presence any more threatening to participation than is the presence of majorities in the legislative chamber or the electorate, who must be convinced to vote a certain way in order for the participation of a particular citizen to be effectual.

The result of a court decision-one produced according to the norms of legal craft that require litigant participation and court responsiveness-thus can be said to carry a strong measure of democratic legitimacy with respect to the litigants involved in the case. This last bit is of course a key qualifier: with respect to the litigants involved in the case. A court's decision can have binding effects far beyond the litigants who are immediately bound by it. It can extend forward in time through stare decisis, binding (to a certain degree) the litigants in future cases for which the original decision serves as precedent. This is the primary sense in which judicial review typically impacts the legal landscape; its greatest strengths, and its biggest problems, usually lie not in the effects of a decision on the immediate litigants, but in the lasting effects of that decision through its application to other litigants (and to parties who change their behavior to avoid becoming litigants-what I have called "conforming nonlitigants"151) in future cases.

Future litigants and conforming nonlitigants who are in this sense bound by a court decision have not themselves participated in the process of making that decision. But this does not mean that the decision is democratically illegitimate with respect to them, any more than the fact that citizens typically do not directly participate in the making of laws means that those laws cannot legitimately bind them. In both cases, the key is accountability-or, perhaps more accurately, reliability of representation. Accountability in the political branches works through electoral control and interest representation; accountability in the judicial branch works through interest representation alone. But it works nonetheless, and remarkably well in most cases. ${ }^{152}$

150. Edward H. Levi, An Introduction to Legal Reasoning 4 (1949).

151. Peters, Adjudication, supra note 15 , at $372-74$.

152. Again, the description of adjudication as representation that follows derives from my more extensive treatment in id. at 360-78. 
lmagine a simple court case. We will start with a common law case rather than a constitutional one, although constitutional cases are at the center of minimalist arguments. Constitutional cases pose complexities that are best put to one side for the moment (to be examined in Part Il.C). Moreover, in order to understand how interest representation works in constitutional cases, it is first necessary to understand how it works in the common law.

We can use a real-world example that I have used before. ${ }^{153}$ In Dillon v. Legg, Margery Dillon brought a claim for negligent infliction of emotional distress against the driver of a car, David Luther Legg, who had negligently struck and killed Dillon's young daughter while Dillon looked on. ${ }^{154}$ Under existing California case law, Dillon could not recover for emotional distress unless she had been put in fear for her own safety by the defendant's conduct. ${ }^{155}$ This rule did not help Dillon, since she apparently had not been within the "zone of danger" created by Legg's negligence (or at least she did not allege that she had been). On this basis, the trial court dismissed Dillon's complaint. On appeal to the California Supreme Court, Dillon argued that the emotional distress rule should be extended to encompass emotional injury that, like Dillon's, arose not from fear for the plaintiff's own safety but from the trauma of witnessing the death of a close relative. ${ }^{156}$ The state supreme court agreed and reversed the dismissal.

The California Supreme Court's decision in Dillon produced a new tort rule in that state: Plaintiffs could now recover in tort for emotional distress suffered as a result of witnessing the death of a close relative through the negligence of the defendant. This rule had a profound impact on many others in California who were not parties to that particular case. ${ }^{157}$ lnjured persons in the position of Margery Dillon could now bring lawsuits and potentially recover damages for their injuries; tortfeasors in the position of David Legg (and their insurance carriers) could now be held liable and forced to pay these damages. The impact on the law was just as strong as if the new liability rule had been enacted by the California legislature. But none of the parties affected, with the exception of Dillon and Legg themselves (and probably Legg's insurance carrier), had participated in creating the rule. Was the rule democratically illegitimate as a result? ${ }^{158}$

153. See id. at $379-91$.

154. 441 P.2d 912,914 (Cal. 1968) (en banc).

155. See id. at $914-15$.

156. See id.

157. The impact extended to other states as well. See P.G. Guthrie, Annotation, Right to Recover Damages in Negligence for Fear of Injury to Another, or Shock or Mental Anguish at Witnessing Such Injuries, 29 A.L.R.3d 1337, 1346, 1360-61 (1970). Dillon apparently was the first American decision recognizing emotional distress liability to plaintiffs outside the "zone of danger."

158. I put aside the obvious point that the California legislature could have overridden the Dillon rule. 
Not if we recognize the extent to which Dillon and Legg served as interest representatives of these similarly situated litigants and conforming nonlitigants. Imagine a subsequent plaintiff, Krouse, whose wife has been struck and killed by a negligent driver, Graham, while removing groceries from the back of the Krouses' parked car. ${ }^{159}$ Krouse sues Graham for negligent infliction of emotional distress arising from the trauma suffered by Krouse as a result of witnessing the accident. In defending the lawsuit, Graham will have the same interests that Legg had in defending the Dillon case; he will want to present the same kinds of facts, make the same kinds of legal arguments, and avoid the same kinds of relief. But of course Legg has already presented those facts, made those arguments, and attempted to avoid that relief in the precedential case. The rule that now binds Graham-tortfeasors in his position must compensate plaintiffs in the position of Krouse-has been created by Legg acting in much the same way that Graham would have acted in producing the rule.

Legg, that is, has acted as the interest representative of Graham and other similarly situated litigants now bound by the rule Legg participated in creating. There is of course no guarantee that Legg's efforts have produced the best possible outcome. (Certainly Graham does not think they have.) But there is no guarantee of that in statutory legislation, either; there is only the safegnard of a mechanism that ensures a representative's motive to act in the constituent's best interests. In the democratic legislative process, that safeguard rests primarily in the electoral system. In common law adjudication, the safeguard rests in the process of interest representation through the binding only of similarly situated future litigants.

And note the crucial fact that Graham is free to argue that the court in his case should reach a different result-should not apply the rule created in Dillon v. Legg-either because that rule is a bad one and should be overturned or, more likely, because the circumstances of his case are materially dissimilar to those of Dillon. The latter is in fact precisely what Graham did in the real case upon which this hypothetical is based. In that case, unlike in Dillon, the plaintiff Krouse had not actually seen Graham's car strike his wife; instead, he "knew [his wife's] position an instant before the impact, observed defendant's vehicle approach her at a high speed on a collision course, and realized that defendant's car must have struck her." 160 Graham argned that this fact was a material distinction from Dillon that required the court to reach (or at least justified the court in reaching) a different result: no liability. The California Supreme Court did not accept this distinction, holding that the Dillon rule governed Graham's case. But in Deboe v. Horn, the California Court of Appeal refused to apply Dillon to allow liability to a plaintiff who had been summoned to the emergency room immediately following an acci-

159. See Krouse v. Graham, 562 P.2d 1022, 1024 (Cal. 1977) (en banc).

160. Id. at 1031. 
dent that had paralyzed her husband. ${ }^{161}$ The defendant in Deboe successfully argued that the distinction between directly witnessing an accident (through some combination of senses) and hearing about it soon afterward was material enough to preclude liability in the latter circumstance.

The point here is that future litigants, like Graham, themselves have the opportunity to argue about which precedents should be followed and what their implications should be. The decision of subsequent cases will, in this sense, be as much the product of litigant participation as the decision in the precedential case. Rarely does a precedential holding apply so squarely as to bind future litigants absolutely.

To the extent, then, that court decisions bind people, they do so as the products of a decisionmaking procedure that respects and incorporates the democratic values of participation and representation. Court decisions are made not just by judges, hut by judges and litigants; and in many ways litigants are the primary authors of a decision. These litigantlawmakers serve as interest representatives of future litigant-subjects (and conforming nonlitigant-subjects). In this sense they are accountable to those bound by the laws they make. Adjudication may be differently democratic, and possibly (more on this below) less democratic, than political decisionmaking. But it is inaccurate to say that adjudication is nondemocratic.

\section{Constitutional Cases}

Constitutional cases, the primary worry of the new minimalists, are different. They are unique, of course, in the familiar sense that their results often cannot be overridden by ordinary political processes. But they also are different in the sense that their impact-their binding effect-might be thought to extend beyond both the immediate litigants and those who are similarly situated to them.

Take Romer $v$. Evans as an example. ${ }^{162}$ At issue in that case was the validity under the Equal Protection Clause of Amendment 2, a provision of the Colorado Constitution prohibiting state and local government from treating homosexuality as the basis of "any minority status, quota preferences, protected status or claim of discrimination."163 The plaintiffs in that case were "homosexual persons, some of them government employees," who "alleged that enforcement of Amendment 2 would subject them to immediate and substantial risk of discrimination on the basis of their sexual orientation," and municipalities and other units of state and local government "which had acted earlier to protect homosexuals from discrimination but would be prevented by Amendment 2 from con-

161. 94 Cal. Rptr. 77, 79-80 (Ct. App. 1971).

162. 517 U.S. 620 (1996).

163. Colo. Const. art. II, $\S 30 \mathrm{~b}$. 
tinuing to do so."164 The defendants were the State of Colorado, Governor Roy Romer, and various other state officials.

When the Supreme Court struck down Amendment 2 in Romer on the ground that it violated the Equal Protection Clause, the immediate plaintiffs and, more to the point, the State of Colorado were of course bound by the decree. Colorado no longer could enforce the Amendment against any of the plaintiffs. Nor could Colorado enforce the Amendment against anyone else; the doctrines of issue preclusion and stare decisis would see to that. And nonparties in the position of Colorado were in a sense "bound" as well. Romer was a Supreme Court decision interpreting the Constitution of the United States. As such, other states and localities could no longer enforce legislation materially similar to Amendment 2 without facing the certain invalidation of that legislation pursuant to Romer in federal or state court.

So far, none of this threatens the picture of adjudication as a participatory and representative process. The State of Colorado was legitimately bound by the decree in Romer because it participated fully in the making of the decision. Other states and localities seeking to enforce similar laws also were legitimately bound, because their interests were represented by the similarly situated State of Colorado. And note that to the extent other states and localities are able to demonstrate, through proofs and reasoned arguments, that the legislation they want to enforce is materially different from Amendment 2 , they will be able to escape the binding effect of that decision. (This is in fact what occurred in Equality Foundation of Greater Cincinnati, Inc. v. City of Cincinnati, in which the City of Cincinnati succeeded in convincing the Sixth Circuit that a provision of its city charter that was similar to Amendment 2 nonetheless was sufficiently distinct that it could survive equal protection scrutiny. ${ }^{165}$ The Supreme Court denied certiorari. ${ }^{166}$ )

The potential problem, however, lies in the apparently broad "horizontal" binding effect of Romer. We can think of a binding effect exerted by a precedential decision upon subsequent similarly situated litigants (or conforming nonlitigants) as vertical, and of a binding effect exerted relatively contemporaneously upon nonlitigants by means other than stare

164. 517 U.S. at 625.

165. See Equality Found. v. City of Cincinnati, 128 F.3d 289, 296 (6th Cir. 1997). According to the court,

[T]he language of the Cincinnati Charter Amendment, read in its full context, merely prevented homosexuals, as homosexuals, from obtaining special privileges and preferences . . . from the City. In stark contrast, Colorado Amendment 2's far broader language could be construed to exclude homosexuals from the protection of every Colorado state law, including laws generally applicable to all other Coloradans, thus rendering gay people without recourse to any state authority at any level of government for any type of victimization or abuse which they might suffer by either private or public actors.

Id.

166. Equality Found. v. City of Cincinnati, 525 U.S. 943 (1998). 
decisis as horizontal. The horizontal effects of Romer fall upon citizens of Colorado (or of other states) who benefited in some way from the existence and enforcement of Amendment 2 (or of similar legislation). For example, citizens who received some ideological or perhaps religious satisfaction from the enforcement of a law against what they perceived to be "special treatment" for homosexuals are "bound" by the decision in Romer in the sense that they no longer can enjoy that satisfaction. Perhaps more concretely, Romer's result means that scarce state money will be spent to enforce laws against sexual-orientation discrimination; people who otherwise would receive that money no longer will receive it and thus are "bound" by Romer. Such people did not participate in the decision; nor were they as similarly situated to the defendant in Romer (the State of Colorado) as were other states and municipalities. Did the decision therefore lack democratic legitimacy with respect to them?

This is a tricky question, to which there are two mutually reinforcing answers. The first answer is that it is not entirely true that interested parties other than the original plaintiffs and defendants in Romer were unable to participate in the litigation. Romer was originally filed in Colorado state court; the Colorado Rules of Civil Procedure, tracking the Federal Rules, allow intervention of right by a third party who "claims an interest relating to ... the subject of the action and ... is so situated that the disposition of the action may as a practical matter impair or impede his ability to protect that interest, unless the applicant's interest is adequately represented by existing parties."167 Federal Rule of Civil Procedure 24(a), upon which the Colorado rule is based, has been interpreted to allow intervention by third parties with an interest in upholding, or invalidating, a particular government policy or decision. ${ }^{168}$ Thus third parties

167. Colo. R. Civ. P. 24(a); cf. Fed. R. Civ. P. 24(a)

168. See, e.g., Natural Resources Defense Council v. United States Nuclear Regulatory Comm'n, 578 F.2d 1341, 1345 (10th Cir. 1978) (allowing intervention by mining companies in litigation challenging legality of issuance of uranium mill licenses without preparation of environmental impact statements); Smuck v. Hobson, 408 F.2d 175, 180-81 (D.C. Cir. 1969) (allowing intervention by parents whose children attended school district accused of unconstitutional policies); United States v. City of Niagara Falls, 103 F.R.D. 164, 166 (W.D.N.Y. 1984) (allowing intervention by association of businesses who sent waste to public facility being sued by United States for violating Clean Water Act); Baker v. Regional Higb School Dist. No. 5, 432 F. Supp. 535, 537 (D. Conn. 1977) (allowing intervention of residents of less populous towns in lawsuit brought by residents of more populous towns challenging constitutionality of scbool district apportionment). As the Smuck and Baker decisions illustrate, courts have not limited intervention to those whose potentially affected interests are pecuniary. In Smuck the intervening parents' interest was "concern for their children's welfare," 408 F.2d at 180, while in Baker it was citizens' interests "as voters, residents, and parents of school children." 432 F. Supp. at 537 . More broadly, many decisions have allowed Rule 24 intervention of right based on the potential impact of stare decisis on the intervenors' interests. See generally 7C Charles Alan Wright et al., Federal Practice and Procedure $\$ 1908$ (2d ed. 1986 \& Supp. 2000), and cases cited therein.

Courts have divided on the question of wbether a potential intervenor under Rule 24 must demonstrate Article IIl standing, and the Supreme Court has not resolved the issue. See Wright, supra, at $\S 1908$; see also, e.g., Planned Parenthood v. Ehlmann, 137 F.3d 573, 
who were interested in the continued enforcement of Amendment 2, and who could demonstrate that the existing defendants were not adequately representing their interests, might have been allowed to intervene in the litigation had they sought to do so.

Short of actual intervention as parties in the lawsuit, interested third parties could have filed amicus curiae briefs with the Supreme Court pursuant to Supreme Court Rule 37.169 Two groups of amici actually did this in Romer, although neither of them supported upholding Amendment 2.170

Thus, there are a number of means by which interested third parties can and frequently do participate in the Court's decisionmaking process in important constitutional cases. ${ }^{171}$ Even if these means were not availa-

576-77 (8th Cir. 1998) (requiring Article III standing for intervention); Building \& Constr. Trades Dep't v. Reich, 40 F.3d 1275, 1282 (D.C. Cir. 1994) (same); cf., e.g., Associated Builders \& Contractors v. Perry, 16 F.3d 688, 690 (6th Cir. 1994) (not requiring Article 111 standing for intervention); Yniguez v. Arizona, 939 F.2d 727, 731 (9th Cir. 1991) (same); United States Postal Serv. v. Brennan, 579 F.2d 188, 190 (2d Cir. 1978) (same). Recent Supreme Court decisions have limited standing in the federal courts. See, e.g., Steel Co.v. Citizens for a Better Env't, 523 U.S. 83, 105 (1998) (denying standing to environmental group suing business for violating Emergency Planning and Community Right-To-Know Act); Raines v. Byrd, 521 U.S. 811, 829-30 (1997) (denying standing to members of Congress seeking to challenge constitutionality of Line Item Veto Act); Lujan v. Defenders of Wildlife, 504 U.S. 555, 562-63 (1992) (denying standing to environmental groups suing Secretary of Interior for failure to interpret correctly Endangered Species Act); Allen v. Wright, 468 U.S. 737, 750-66 (1984) (denying standing to parents of black schoolchildren suing Internal Revenue Service for failure to deny tax-exempt status to racially discriminatory private schools). Despite these decisions, however, it is far from clear that the Court would require Article III standing for intervention, since the fact that intervention occurs only when some plaintiff with standing already has brought a lawsuit might change the relevant calculus. If the Court were to impose such a requirement, the opportunities for meaningful participation by third parties I outline here would be significantly reduced, and with them potentially the legitimacy of many federal court decisions. Thus there are strong reasons of legitimacy to allow broad standing to intervene in constitutional cases. As 1 have argned elsewhere, however, many of those same reasons favor justiciability doctrines that ensure that at least one plaintiff has an actual personal stake in the controversy. See Peters, Adjudication, supra note 15, at 420-30.

169. See Sup. Ct. Rule 37(1) (allowing filing of amicus curiae brief "that brings to the attention of the Court relevant matter not already brought to its attention by the parties").

170. See Brief of the Human Rights Campaign Fund et al., as Amici Curiae in Support of Respondents at 1-2, Romer v. Evans, 517 U.S. 620 (1996) (No. 94-1039); Brief of Laurence H. Tribe et al., as Amici Curiae in Support of Respondents at 1 (No. 94-1039). Notably, many groups on both sides of the issue-newly aware of the stakes after Romerfiled amicus briefs in the Cincinnati case. See Equality Found. v. City of Cincinnati, 128 F.3d at 291 (listing amicus briefs filed by National Legal Foundation; American Enterprise Institute for Public Research; Equal Rights, Not Special Rights; American Family Association of Ohio; Cincinnati Federation of Teachers; NAACP Legal Defense \& Educational Fund, Inc.; and others).

171. It is true, of course, that these participatory options are expensive, certainly more so than voting, the baseline mode of political participation. A Colorado citizen thus is much more likely to vote in favor of Amendment 2 than to file an amicus brief or a motion to intervene in a constitutional lawsuit challenging Amendment 2's validity. But a citizen also is much more likely to vote in favor of a ballot issue than to undertake more costly 
ble, however, those bound horizontally by most constitutional decisions striking down legislation, including Romer, would be represented in another important sense. In Romer, the defendant was the State of Colorado, represented in the litigation by its state solicitor. ${ }^{172}$ The state solicitor is an official appointed by the state's Attorney General, ${ }^{173}$ who is in turn elected by the people of the State of Colorado. ${ }^{174}$ Thus, the interests, such as they were, of the citizens of Colorado in upholding Amendment 2 were represented by their state solicitor in the Romer litigation through traditional mechanisms of political accountability, quite apart from interest representation through stare decisis. This will be true in most constitutional cases, which typically involve the government as a party. ${ }^{175}$

In constitutional cases, then, the interests of those nonparties who are bound horizontally typically are no less represented than the interests of nonparties who are bound vertically, through stare decisis. Constitu-

means of political participation-organizing a ballot drive, running for office, or using the mass media to speak to large numbers of people-despite the likelihood that these more costly types of participation are also more likely to be effective in achieving the citizen's ideological goals. In this respect, the option of (effective) participation in adjudication is not clearly more costly than the option of (effective) participation in politics. In both contexts, the typical citizen is likely to rely upon the efforts of organized groups with similar interests-groups that can intervene or file amicus briefs in litigation and can undertake expensive efforts like lobbying, advertising, and campaign funding in the political arena. Indeed, the participation of organizations representing the interests of groups of citizens-for example, the NAACP Legal Defense Fund, which intervened in the Cincinnati case, see supra note I70-seems at least as likely to be effective in litigation as in politics. This is because the field of competitors in a lawsuit is typically less crowded than the field of competitors in the political arena, and also because there is a smaller group of decisionmakers-a single judge or perhaps an appellate panel, rather than the majority of the electorate or the majority of the legislature-to win over.

It is also true, and important, that litigation, like politics, is expensive for parties on all sides of an issue. Intervening in a lawsuit, or filing an amicus brief, is far more expensive than voting; but so is filing a lawsuit. The expense of intervening in Romer thus was hardly a relative disadvantage for would-be intervenors, any more than the expense of opposing Amendment 2 was a relative disadvantage for those who fought the referendum that enacted it.

To generalize these points: The expense of participating in constitutional litigation does not make that method of decisionmaking any less participatory, and thus any less democratically legitimate, than political decisionmaking. In both adjudication and politics, effective participation can be very expensive, and there is no reason to think that adjudication gives one side of an issue any cost advantage that is not present in politics.

172. In its statutes, Colorado refers to its state solicitor general as the "state solicitor." Colo. Rev. Stat. § 24-31-201(4) (1999).

173. See Colo. Rev. Stat. $\$ 24-31-203(1)$ (1990).

174. See Colo. Const. art. IV, $\$ \S 1,3$.

175. See Peters, Adjudication, supra note I5, at 414-15. Even when the state or federal government is not an original party, the Federal Rules of Civil Procedure require the court to notify the appropriate attorney general if "the constitutionality of [a statute] affecting the public interest is drawn in question," Fed. R. Civ. P. 24(c), and permit the court to allow the government to intervene in such a case. See Fed. R. Civ. P. 24(b). 
tional cases, though special, are not significantly less democratic than garden-variety litigation. ${ }^{176}$

\section{Representation and Judicial Minimalism}

If judicial review is in this sense democratically legitimate-if it incorporates the same elements of participation and representation that characterize decisionmaking by the political branches-then calls for judicial minimalism appear to lose much of their force. Judicial review becomes just another kind of democratic institution, different from, but not necessarily less legitimate than, congressional lawmaking or executive rulemaking. If judicial review is itself essentially democratic, why should courts defer to the political branches whenever possible, as the new minimalists suggest?

One conceivable answer to this question is that judicial review, while not so nondemocratic as is usually supposed, nevertheless may be less democratic, in ways we care about, than political lawmaking. We may not think that the kind of interest representation that operates through the common law method is a completely satisfactory substitute for the combination of interest representation and electoral control that characterizes the political system. There may be something unique and important about the ability to elect our representatives periodically, and to elect others to replace them, that is not present in even the most participatory and representative example of constitutional adjudication. If so, then we may still prefer courts to act in a minimalist fashion when exercising the power of judicial review.

Someone giving this answer, it seems to me, might reasonably be asked to identify that "something unique and important" about electoral accountability that is lacking in a properly functioning system of adjudication. A possible response to this challenge is suggested by the work of Robert Burt. For Burt, the core ideal of democracy is the absence of

176. The functioning of what I have called "adjudication as representation" in constitutional cases thus illustrates the important distinction between majoritarian decisionmaking and democratic decisionmaking; a process may be the latter without being the former. See Peters, Adjudication, supra note 15, at 419-20. Indeed, the decision of Romer was even more saliently countermajoritarian than the typical exercise of judicial review, because the Colorado Amendment invalidated by the Court had been enacted by popular referendum. See Romer v. Evans, 517 U.S. 620, 623 (1996). And, just as the decision in Romer can be seen as democratic though countermajoritarian, it also can be seen as the product of a more deliberative decisionmaking process than the enactment of Amendment 2 is likely to have been. In Part IIl, infra, I explain why judicial decisionmaking about issues of individual rights is likely to be more deliberative, and generally of better quality, than political decisionmaking about such issues. In the particular context of popular referenda, this comparison seems even more one-sided in favor of adjudication. (Sunstein apparently agrees, tentatively suggesting that " $[\mathrm{r}]$ eferenda may well be based on inadequate information and on popular passions that are insufficiently influenced by reason-giving and understanding of context," and that "[p]erhaps the Court should review the outcomes of referenda with an unusually high degree of skepticism." Sunstein, One Case at a Time, supra note 8, at 133-34.) 
coercion; true democratic legitimacy arises only when all parties who will be bound by the resolution of an issue have agreed to that resolution. It is not mere participation in decisionmaking that produces legitimacy, but agreement among the participants. ${ }^{177}$ From this view of democracy, one might construct a critique of adjudication on the grounds that adjudication is not about resolving disputes by agreement, but rather about the "authoritative resolution of disputes [by the court] that overrides the subjective evaluation of [one] of the contesting parties." 178 Because the imposition of judicial authority involves coercion of the losing party, adjudication cannot claim the same degree, or perhaps the same type, of legitimacy that political decisionmaking can claim.

The difficulty with this argument as a brief for minimalism is that the alternative to resolving issues by adjudication-resolving them by majoritarian politics-itself inevitably involves coercion. The winning political majority authoritatively imposes its decision upon the losing political minority no less than the court authoritatively imposes its decision upon the losing litigant. Only in nearly nonexistent cases of unanimity is political decisionmaking truly a matter of agreement rather than coercion. Burt acknowledges this difficulty, ultimately suggesting only that unanimous consent, though "almost impossible to obtain in practice," should be "our guiding ideal in all social relations and in all institutions." 179 Acknowledging the virtual impossibility of unanimous consent in the real world, however, negates the legitimacy gap between (authoritarian) adjudicative decisionmaking and (equally authoritarian) majoritarian politics.

For the sake of argument, though, I am willing to assume that there is something special about electoral accountability that, all else being equal, provides a reason for preferring political to adjudicative decisionmaking. The problem is that all else is not equal. As I argue in the next Part, although arguably adjudication is somewhat less democratic in general than political decisionmaking, it is more deliberative and thus more effective on issues of rights.

\section{IIl. Courts AND Rights}

The case for the new minimalism depends not only on the idea that adjudication (at least, judicial review) is less democratically legitimate than political decisionmaking; it also depends partly on the notion that courts have no special institutional competence to decide issues of individual or minority rights. ${ }^{180}$ The new minimalists prefer that, at least in

177. See Burt, supra note 85 , at 368 ; see also supra Part I.B.3.a.

178. Burt, supra note 85 , at 98 .

179. Id. at 374 .

180. This premise is shared by many proponents of "deliberative democracy." Amy Gutmann and Dennis Thompson, for instance, decry "the view that courts are the forum of principle in our democratic system, and that legislatures are incapable, or demonstrably less capable, of considering moral principles in the making of policy." Amy Gutmann \& 
the first instance, matters of individual rights ${ }^{181}$ be left to the political process, ${ }^{182}$ and that courts primarily limit themselves to promoting deliberation and accountability in that process. ${ }^{183}$

Dennis Thompson, Democracy and Disagreement 48 (1996). But they acknowledge that "[i]f the judiciary turns out to be better able to protect some or all basic liberties and opportunities, then a deliberative perspective will grant the judiciary special authority to review those rights." Id. Whether this is so, they assert, "is a question of institutional design, not fundamental principle, and it remains more open to empirical investigation than constitutional democrats typically suggest." Id. Gutmann and Thompson are surely correct that the branches' comparative capacity for protecting individual rights "is a question of institutional design," but their suggestion that it is "open to empirical investigation" seems a bit naive: Whether the Court or Congress has been more successful at protecting rights depends upon entirely subjective, and not at all empirical, conclusions about which rights are worth protecting. A satisfying assessment of comparative institutional advantages in the protection of rights must, it seems to me, be divorced from particular subjective evaluations of rights, and thus from subjective evaluations of "success" or "failure" in particular cases. I try to accomplish such an assessment in this Part.

181. Because I am not sure there is a meaningful difference between "individual" and "minority" rights, I will refer to both categories of rights as "individual rights." In my view, rights one might have as a member of a minority group-for instance, the right of a member of a racial minority against discrimination on the basis of that membershipreally devolve into rights one has as an individual, regardless of one's membership in a minority. Such rights may take on special significance, however, because one's membership in a minority puts them at risk.

182. For example, each of the specific contexts in which Sunstein endorses minimalism in One Case at a Time involves individual rights. See Sunstein, One Case at a Time, supra note 8, at 75-116 (assisted suicide); id. at 117-36 (affirmative action); id. at 137-71 (discrimination based on sex or sexual orientation); id. at 172-210 (free speech). Dorf and Fallon both similarly endorse minimalism in assisted-suicide cases. See Dorf, supra note 11, at 62-63, 73; Fallon, supra note 11, at 137-41, 145-48. Dorf also advocates minimalism in cases involving the Fifth Amendment privilege against self-incrimination and the Fourth Amendment protection against unreasonable searches and seizures. See Dorf, supra note 11, at 70-73. Burt criticizes the Court for its lack of minimalism in the contexts of abortion, see Burt, supra note 85 , at $344-52,357-62$, and the death penalty. See id. at $327-44,373-74$.

183. This is primarily Sunstein's theme. See Sunstein, One Case at a Time, supra note 8, at 32-33 (defending "democracy-promoting" use of clear-statement principle in case involving denial of passport to known communist); id. at 33 (defending, as means of promoting deliberation, Justice White's concurrence in Griswold v. Connecticut, 381 U.S. $479,502-07$ (1965), which rejected an anti-contraception statute on rational-basis grounds); id. at 34-35 (defending, as means of promoting democratic accountability, Court's rejection of Civil Service Commission policy barring employment of aliens on ultra vires grounds); id. at 33-34, 117-36 (defending Court's casuistry in affirmative-action cases as means of promoting public deliberation). Fallon has picked up on this theme as well, touting "suspect-content," "nonsuspect-content," and "purpose" tests as means of promoting rational and unbiased deliberation in government decisionmaking. See Fallon, supra note 11, at 88-105. Of course, Alexander Bickel was the first to draw out this theme. See, e.g., Bickel, supra note 3, at 148-56 (extolling the doctrine of desuetude as a way to encourage political deliberation); id. at 156-64 (connecting the nondelegation doctrine to political accountability); id. at 164-69 (doing the same with the clear-statement doctrine). Burt advocates the use of many of Bickel's "passive virtues" as means of "pursuing conversation" between the Court and the political branches, and among the political branches, "rather than imposing silence." Burt, supra note 85 , at 362 ; see also id. at 
But there are at least three good reasons to believe that courts do in fact tend to be better decisionmakers than political institutions when it comes to individual rights. The first reason (a familiar one) is the classic defense of judicial review: Because courts are less subject than the political branches to majoritarian pressures, they are better able to protect individual rights against the majority. Volumes have been written about this justification for judicial review, and I discuss it and its implications for minimalist arguments only briefly below.

The other two reasons are less familiar, and I devote more time to discussing them. The second reason is that the courts' mode of operation-relatively isolated from public scrutiny and mass-media attentionlends itself more to true deliberation than do the high-profile decisionmaking processes of the political branches. The third reason is that the common law decisionmaking method employed by courts, characterized by gradualism and analogical reasoning, is better suited to making decisions about individual rights than are the more instantaneous and holistic decisionmaking processes of the political branches.

\section{A. The Countermajoritarian Advantage}

The courts' role as protector of individual rights has been championed since the Founding on the ground that courts, relatively insulated from majoritarian pressures, are better suited to that role than the political branches. Hamilton famously wrote in The Federalist No. 78 that the

independence of the judges is . . requisite to guard the Constitution and the rights of individuals from the effects of those ill humors which . . . sometimes disseminate among the people themselves, and which . . . have a tendency . . . to occasion dangerous innovations in the government, and serious oppressions of the minor party in the community. ${ }^{184}$

In my view, Sunstein and the other new minimalists undervalue this classic argument. Like John Hart Ely, from whose representation-reinforcement model of judicial review Sunstein and Fallon borrow liberally, the new minimalists do not explain how even a truly deliberative, genuinely accountable, broadly and fairly participatory system of majoritarian government can avoid occasionally trampling on individual rights in the name of the greater good. If one believes that individual rights have some meaning apart from the greater good, then one must acknowledge the need to protect them even in a well-functioning majoritarian system. And Sunstein does seem to endorse, if somewhat vaguely, the notion that (at least some) individual rights are not reducible to utilitarian or democracy-reinforcing goals. ${ }^{185}$

359-62 (embracing clear-statement principles and void-for-vagueness and ripeness doctrines).

184. The Federalist No. 78, supra note 2, at 440.

185. For example, Sunstein defends Brown v. Board of Education, 347 U.S. 483 (1954), as a "compelling case[ ]" in which "the underlying judgment of (constitutionally 
Given this belief, the readiness of Sunstein and the other new minimalists to assign to the judiciary a secondary or back-up role in protecting individual rights, a role that fully vests only in the presence of clear political failure or substantial judicial certainty, is somewhat incongruous. Why should individual rights ever be put at the mercy of a self-interested majority? The judiciary's insulation from majoritarian pressures would seem to give it a powerful and ubiquitous advantage in recognizing individual rights. On what grounds, then, should the judiciary defer to a political system that is subject to those pressures? ${ }^{186}$

One ground might be the superior democratic legitimacy of the political process. But that ground is made much less appealing by the recognition that, as explained in the previous section, adjudication is itself democratically legitimate in an important sense. If adjudication is seen to be democratically legitimate-participatory and representative, like the political system-then the countermajoritarian difficulty becomes a countermajoritarian advantage: Adjudication is capable of protecting in-

relevant) political morality is insistent." Sunstein, One Case at a Time, supra note 8 , at 38 . This defense hints at a deeper substance than anything recognized by Ely, who justifies Brown solely in representation-reinforcement terms. See Ely, supra note 52, at 150-51. Sunstein also ultimately defends the Court's decision in Romer v. Evans, 517 U.S. 620 (1996), on substantive, not procedural, grounds:

I will assert, without defending the point here, that [a] notion of equality [that would protect individuals from discrimination on the basis of sexual orientation] does indeed connect very well with the best understanding of the equality principle that underlies the Civil War amendments. Simply as a matter of abstract constitutional theory, the anticaste principle ... draws discrimination on the basis of sexual orientation into considerable doubt.

Sunstein, One Case at a Time, supra note 8 , at I60.

186. Mark Tushnet offers two connected answers: (1) that majoritarian politics ultimately is capable of policing itself with respect to individual rights, see Tushnet, Taking the Constitution Away, supra note 7 , at 128 , and (2) that the Court in any case tends over time either to track majority values in such matters or to be ineffective in resisting them. See id. at 152-53. Tushnet acknowledges that his argument with respect to (I) is largely aspirational, see id. at 128 , and he ultimately defends it with a twist on Learned Hand's famous dictum that "[1]iberty lies in the hearts of men and women; when it dies there, no constitution, no law, no court can save it," Learned Hand, The Spirit of Liberty I90 (1960). See Tushnet, Taking the Constitution Away, supra note 7, at 71 ("I doubt that the people of the United States have become so degenerate that the principles of the Declaration of Independence no longer mean anything to us. If the substantive skeptic is right [that they have], however, it seems wildly unlikely that the courts can save us from ourselves."). Tushnet also admits with respect to (2) that much relies on the idea of long-term convergence between judicial decisionmaking and majority values, and indeed on how one defines the relevant "majority." See id. at I34.

Although I concede the force of Hand's aphorism, I am skeptical that political majorities, acting through their representatives in the political branches, are likely to do a better job than courts of making particular decisions about antimajoritarian rights. I try to justify this skepticism in Part III and, using Plessy v. Ferguson, 163 U.S. 537 (1896), as an example, in Part V.B. I do tend to agree with Tushnet that constitutional doctrine, perhaps especially in the area of individual rights, tends over the long haul to track majority values, but I think the temporal qualifier carries more weight than Tushnet assigns to it. See infra Part V.B. 
dividual rights from majoritarian excess while remaining democratically accountable to those most affected by judicial decisions. Judicial review may be countermajoritarian, but it is not antidemocratic. And the argument for a general rule of judicial deference to the political process in the area of individual rights becomes less convincing.

\section{B. Opacity, Transparency, and Deliberation}

Deliberation is not necessarily promoted by transparency; indeed, it is frequently hindered by it. This is a point that Sunstein himself has made quite powerfully in the past. In The Partial Constitution, Sunstein sides with Madison against Jefferson in favor of the closing of the Constitutional Convention in 1787:

On Madison's view, it was best "to sit with closed doors, because opinions were so various and at first so crude that it was necessary they should be long debated before any uniform system of opinion could be formed. Meantime the minds of the members were changing, and much was to be gained by a yielding and accommodating spirit. . . . [B]y secret discussion no man felt himself obliged to retain his opinions any longer than he was satisfied of their propriety and truth, and was open to the force of argument." 187

1ndeed, the Federalists thought that opacity was necessary for true democratic deliberation. They distrusted open public discussion and, as James Martin has written, "believed that the public interactions and debates that are a part of any democracy should take place via the representative mechanisms that operate through the legal institutions of the state."188

The relationship between the opacity and the quality of deliberation recently surfaced in the debate over whether the Senate, sitting as a court of impeachment in the trial of President Clinton, should deliberate publicly or behind closed doors. Some, like Iowa Senator Tom Harkin, opposed deliberations in "secret session" and argued that opening the debate "would send an important message. The public has a right to know how the Senate reaches its final decision on the removal or acquittal of the President." 189 Others, like Alabama Senator Richard Shelby, held a different view: "I think we explain[ ] to our constituents how we're going to vote as we vote and afterwards. . . . But I believe that the deliberations ought to be like every jury in America, they ought to be behind closed

187. Sunstein, Partial Constitution, supra note 8 , at 22 (quoting 3 Max Farrand, The Records of the Federal Convention of 1787, at 479 (1911)).

188. James P. Martin, When Repression 1s Democratic and Constitutional: The Federalist Theory of Representation and the Sedition Act of 1798, 66 U. Chi. L. Rev. 117, 118 (1999).

189. Office of Senator Tom Harkin, Press Release, Harkin/Wellstone Make Final Push to Open Final Deliberations, Federal Document Clearing House, Feb. 8, 1999, available in 1999 WL 2222309. 
doors where we can be candid . .."190 In the end, those advocating open-door deliberations failed to achieve the two-thirds majority necessary to waive the Senate rule requiring secret debate. ${ }^{191}$

Madison, Senator Shelby, and Sunstein himself have recognized that the glare of the public spotlight is not conducive to the candidness and open-mindedness necessary to true deliberation. This is so for the same reasons that support representative rather than direct democracy: Public opinion may be raw, "based on inadequate information and on popular passions that are insufficiently influenced by reason-giving and understanding of context."192 Exposing important decisions, and the processes of making them, to instantaneous and continuous public scrutiny threatens to infect representative democracy with the sorts of emotional, kneejerk tendencies it was designed to avoid. ${ }^{193}$

This is especially so when the decisions to be made involve not simply policy issues, but questions of individual rights against the majority. Writing of the dangers of referenda in the affirmative action context, Sunstein notes the risk that "outcomes will not be based on a careful assessment of facts and values, but instead on crude 'we-they' thinking." 194 This point can be generalized across all decisions involving individual rights. Questions of individual rights are inherently "we-they" affairs: The majoritarian "we" is pitted against the individual or minority "they." True deliberation about such questions-decisionmaking characterized by reason-giving, openness to opposing argnments, consideration of various relevant perspectives, and willingness to compromise-is made difficult from the start in the political system, where the ultimate decisionmakers, the citizens, by definition have something to gain or to lose. Deliberation is made all the more difficult when representatives are constantly bombarded, through public opinion polls and the ever-more-massive media, by the self-interests they are supposed to be filtering. ${ }^{195}$

190. This Week (ABC television broadcast, Feb. 7, 1999), available in $1999 \mathrm{WL}$ 5920454.

191. See Jim Abrams, Senators Fail in Bid to Open Debate, AP, Feb. 9, 1999, available in 1999 WL 11926331.

192. Sunstein, One Case at a Time, supra note 8 , at 133.

193. See Bessette, supra note 139, at 207-10 (describing efficacy of behind-closeddoors deliberation); cf. Martin, supra note 188, at 153 (explaining Federalist view that "discussing issues through the medium of the mass media and private political organizations . . . introduced enormous inequalities of access [to the political process], inequalities that could be avoided by deliberating through the representative process").

194. Sunstein, One Case at a Time, supra note 8 , at 133.

195. Sunstein himself has fretted about the baleful influence of the modern mass media upon political deliberation. In two recent articles, he has decried the interaction among the media, the Independent Counsel statute, and the impeachment provisions of the Constitution as creating incentives for partisan political attacks and as distracting public attention from important policy issues. See Cass R. Sunstein, Bad Incentives and Bad Institutions, 86 Geo. L.J. 2267, 2276-79 (1998); Cass R. Sunstein, Impeaching the President, 147 U. Pa. L. Rev. 279, 314 (1998). 
The increasing transparency of politics stands in stark contrast to the opaque process of adjudicative decisionmaking. Only very rarely, as in the O.J. Simpson case, does the actual process of adjudication attract significant public attention. What publicity adjudication does draw invariably goes to the trial process, not to the appellate process, where law is made. Appellate court and Supreme Court proceedings are not televised, and only the results of those proceedings tend to receive publicity (and then only wben they decide high-profile issues). And of course the actual deliberations of appellate courts invariably take place behind closed doors.

It is true, and important, that the tools of Supreme Court deliberation-briefs filed by the parties, and transcripts or recordings of oral arguments-and the results of that deliberation-written opinions-usually are made public, more frequently and quickly than ever these days. But these sources only confirm the extent to whicb adjudication is meticulously deliberative. Legal briefs, oral arguments, and court opinions, unlike arguments made in the political realm, typically eschew entreaties to "public opinion" or "the public interest," instead replacing them with arguments based on the interpretation of legal authorities. Briefs, arguments, and opinions also typically address the reasoning both for and against the results they espouse. They are not allowed to be "supported by self-interest or force" 196 or to rely on "[n]aked preferences." "197 They are models of "reason-giving in the public domain."198

The quoted phrases in the previous paragraph are taken from Sunstein's description of "deliberative democracy" in One Case at a Time. Remarkably, though, they describe the everyday adjudicative process mucb more accurately than they describe the everyday political process. ${ }^{199}$ This is because the adjudicative process is, in these important ways, far more "deliberative" than politics typically can be. Part of the reason for this is the much-maligned isolationism of the law-its insulation from worldly affairs, its persistent formalism, its self-referential reliance only on appropriately pedigreed authorities. ${ }^{200}$ Law in our system takes place behind

Sunstein is not the only proponent of "deliberative democracy" to despair at the state of contemporary political deliberation. See, e.g., Gutmann \& Thompson, supra note 180, at 12 ("In the practice of our democratic politics, communicating by sound bite, competing by character assassination, and resolving political conflicts through self-seeking bargaining too often substitute for deliberation on the merits of controversial issues.").

I96. Sunstein, One Case at a Time, supra note 8 , at 25.

197. Id.

198. Id.

199. Cf. Bruce Ackerman, We the People: Foundations 6 (1991) (distinguishing between "normal politics" and "higher [i.e., constitutional] lawmaking"); id. at 24-32 (applying this "dualist" approach to theories of "liberalism" and "republicanism," and articulating a conception of "liberal republicanism" in which "normal politics" embodies the liberal tendencies of the American polity and "higher lawmaking" embodies its republican tendencies).

200. Cf. Dorf, supra note I1, at 8 ("The Justices live and work in relative isolation from major currents of American political, technological, and social life."); Erwin $\mathrm{N}$. 
closed doors, away from the public spotlight and with little regard for it. And this opacity may work to the judiciary's advantage in attracting public trust; a recent survey indicates that the public has more "respect" for the Supreme Court than for the political branches. ${ }^{201}$

It is strange, then, that Sunstein sees judicial review primarily as a tool for increasing the deliberativeness of the political branches. Much of the point of judicial review is that it is more deliberative than the political process, and thus better constituted to produce decisions that require deliberation above all else. As I explain in the next section, the adjudicative brand of deliberation does not lend itself to many kinds of decisionmaking that the political branches are good at. But it does lend itself to decisionmaking about individual rights-when they exist, what they look like, how far they ultimately extend. Decisions about individual rights are particularly poorly made in the spotlight, where they can be distorted by the very pressures that rights are meant to stand against. They are better made by courts, which can, in the current phrase, "fly under the radar" of public scrutiny.

\section{The Common Law Method and Individual Rights}

Lon Fuller, in his famous essay "The Forms and Limits of Adjudication," characterized adjudication as "a form of decision that defines the affected party's participation as that of offering proofs and reasoned arguments." 202 From this description, Fuller deduced that adjudication, virtually by definition, is concerned with-and limited to-deciding "claims of right or accusations of fault." ${ }^{203}$ Adjudication, for Fuller, was entirely about deciding questions of rights. More recently, Ronald Dworkin has taken up the inherent connection between adjudication and rights. 204

Fuller's insight suggests a weakness in the new judicial minimalism: 1t suggests that adjudicative procedures are especially good at producing decisions about individual rights, and thus it undermines the case for deference to the political process with respect to rights issues. In fact, there are three closely related ways in which the common law method of adjudication makes courts better suited than the political process to decide issues of individual rights. First, deciding questions of rights is what courts always have done and are used to doing. Second, the common law brings

Griswold, The Supreme Court, 1959 Term-Foreword: Of Time and Attitudes-Professor Hart and Judge Arnold, 74 Harv. L. Rev. 81, 81 (1960) ("In our situation and tradition, the Supreme Court is inevitably an isolated and remote body.").

201. See Tom R. Tyler \& Gregory Mitchell, Legitimacy and the Empowerment of Discretionary Legal Authority: The United States Supreme Court and Abortion Rights, 43 Duke L.J. 703, 754 (1994).

202. Fuller, supra note I3, at 369.

203. Id.

204. See, e.g., Ronald Dworkin, Taking Rights Seriously 81-130 (1978) [hereinafter Dworkin, Taking Rights Seriously]. 
the element of continuity to decisions about rights, continuity that is generally absent from the political process but is bound up with the very definition of rights. And third, reasoning by analogy allows courts to define rights by reference to particular circumstances, an advantage not typically shared by political decisionmaking. I discuss each advantage in turn.

1. The Connection Between Adjudication and Rights. - Adjudication, at least in the Anglo-American tradition, has always been about rights. This is a virtually definitional fact, springing from the very nature of adjudication. At its core, adjudication is a means of resolving disputes between people, and dispute resolution implies standards by which disputes can be resolved. Unless those standards are to be based on force or happenstance, they must be based upon arguments about rights-that is, upon arguments about why a disputant is entitled to a particular resolution of the dispute.

Consider the classic liberal justification of government as a means of resolving disputes. For Hobbes, the state of nature was characterized by constant, often violent disputes; the solution was the establishment of government, including, crucially, courts of law that could resolve disputes peacefully. ${ }^{205}$ Locke too saw government, and particularly courts, as a solution to the problem of "every Man's being Judge in his own Case," which was one of the "inconveniencies of the State of Nature."206

In nascent liberal theory, the primary function of government thus was adjudicative-the peaceful and authoritative resolution of existing disputes. Of course, we expect modern government to do much more than this. But we still assign to courts the primary task of resolving disputes.

How do courts go about this task? Note that disputes virtually always concern things that have already happened. A farmer has bought a cow that does not produce milk as promised; is he entitled to a refund of the purchase price? A driver has struck a pedestrian in a crosswalk; must she compensate the pedestrian for his injuries? Answering these typical kinds of adjudicative questions requires assessing the consequences of something that occurred in the past. Dispute resolution is an inherently retrospective enterprise.

Faced with an existing dispute, a court has several choices of how to resolve it. The court could tell the parties to fight it out amongst themselves; but this would defeat the purpose of adjudication, which is the peaceful and authoritative resolution of controversies. The court could decide by happenstance, as by tossing a coin; but this hardly justifies the trouble of having courts (anyone could do it), and in any event we are too

205. See Thomas Hobbes, Leviathan 223-34 (C.B. Macpherson ed., Penguin Classics 1986) (1651).

206. John Locke, Two Treatises of Government 326 (Peter Laslett ed., Cambridge Univ. Press 1988) (1690). 
much the children of rationalism in today's society to accept such a resolution as authoritative. Or the court could decide by reason-by hearing what Lon Fuller called "reasoned arguments" 207 from each of the disputants about why he or she or it should win the case. This last option, of course, is the one courts actually choose in our system.

What is meant by a "reasoned argument"? Appeals to force or chance are out, on the grounds just discussed. Appeals to what Sunstein would call a "naked preference" are out as well; merely saying "rule in my favor because it would be in my interest for you to do so" does not carry any weight in our system of adjudication. (And rightly so, because acting on such an appeal would render adjudication superfluous-it would be no different than resolving the dispute by force. In any case, if both disputants make this argument, the court has no basis to choose between them.) The "reasons" backing up an argument to a court must really be reasons; they must be grounded in an appeal to what is right (that is, required by some relevant normative code) ${ }^{208}$ or good (that is, conducive to the furtherance of some good result or to the avoidance of some bad one) .209

As Fuller noted, reasoned argument in adjudication tends to invoke ideas of what is right rather than ideas about what would produce good results. ${ }^{210}$ Why is this? I suspect it is because arguments about good results are not necessarily connected with the core function of adjudication, which is dispute resolution. Again, adjudication for the most part is retrospective; it assesses events that already have occurred. Arguments about good results have no relevance to the assessment of events that already have occurred-because those events already have occurred. An argument that it would be best for society, all things considered, if sellers of livestock bore the risk of latent defects, or if drivers compensated pedestrians injured by their negligence, does not tell a court what to do about a dispute over the sale of a cow that occurred last month, or over a traffic accident that happened last year. The parties to such past disputes will not be affected one way or another by the establishment of a prospective

207. Fuller, supra note 13 , at 365 .

208. The relevant normative code need not involve appeals to "morality," "natural law," or indeed any extrajudicial authorities; it may simply consist of the requirement that judicial precedent be followed. Fuller seems to invoke this latter sense when he defines adjudication as involving "claims of right." See Fuller, supra note 13, at 365-72.

209. I mean "good" here not to refer to conceptions of "the good life" for individuals, but rather to refer to conceptions of "the common good"-i.e., the best state of affairs generally, by whatever criteria one might use to assess it. My distinction between decisions about the "right" and decisions about the "common good" parallels Ronald Dworkin's distinction between decisions of "principle" and decisions of "policy." See, e.g., Ronald Dworkin, A Matter of Principle 2-3 (1985) [hereinafter Dworkin, A Matter of Principle] (summarizing his principle-policy distinction).

210. See Fuller, supra note 13, at 365-72. Again, Fuller apparently uses the idea of "right" in a relatively narrow sense, to signify "rights" arising from specific positive legal authorities rather than "right results" in a broader moral sense. But Fuller is vague about this in his article. See id. 
rule (at least not so far as the disputes in question are concerned). The seller of the cow cannot go back in time and test the cow's milk-production capability before taking the buyer's money; the driver of the car cannot go back and drive more carefully, thus avoiding the pedestrian. It is too late for that.

Arguments about good results-that is, about the best rule to create-thus cannot help resolve existing disputes. Of course, they can help resolve, or avoid, future disputes, insofar as they are arguments about prospective rules. But the creation of prospective rules-through the mechanism of stare decisis-is a function separate from the resolution of existing disputes. The former function is not implied by the latter. Courts can, and sometimes do, resolve disputes without creating or modifying prospective conduct rules. ${ }^{211}$

Because arguments about good results cannot resolve existing disputes, they do not hold a core place in adjudication. But arguments about the right do. Indeed, when arguments about good results are put to one side, arguments about the right are the only kind of reasoned arguments left. If adjudication is characterized by reasoned argumentsas it must be, since force, chance, and naked preference are out-and if reasoned arguments about dispute resolution tend to be arguments about the right, then adjudication is characterized by arguments about the right. Lon Fuller put the syllogism this way:

(1) ... Adjudication is a process of decision that grants to the affected party a form of participation that consists in the opportunity to present proofs and reasoned arguments. (2) The litigant must therefore, if his participation is to be meaningful, assert some principle or principles by which his arguments are sound and his proofs relevant. (3) A naked demand is distinguished from a claim of right by the fact that the latter is a demand supported by a principle; likewise, a mere expression of displeasure or resentment is distinguished from an accusation by the fact that the latter rests upon some principle. Hence, (4) issues tried before an adjudicator tend to become claims of right or accusations of fault. ${ }^{212}$

Adjudication, then, almost inherently involves arguments about the right. As this passage from Fuller (echoed by Dworkin ${ }^{213}$ ) suggests, arguments about what is "right"-about what resolution of a dispute is morally required-are equivalent to arguments about what the disputants

211. The increasing trend toward unpublished opinions in the Federal Courts of Appeals is an important example. See, e.g., Mitu Gulati \& C.M.A. McCauliff, On Not Making Law, 61 Law \& Contemp. Probs., Summer 1998 at 157, 159 (1998) (describing and assessing data on use of unpublisbed opinions and "without comment" dispositions in Courts of Appeals).

212. Fuller, supra note 13 , at 369 .

213. See, e.g., Dworkin, Taking Rights Seriously, supra note 204, at 82-90 (developing his "rights thesis," according to which every case has a morally "right" answer which the litigants in turn have a "right" to see applied). 
have a "right" to. If a decision refunding the cow's purchase price is "right," in the sense of being morally obligatory, then the plaintiff in the case has a "right," or a moral entitlement, to have that decision rendered. ${ }^{214}$ Adjudication, which is fundamentally about determining the right resolution of existing disputes, thus also is fundamentally about determining the rights of the parties to those disputes. Determining parties' rights is simply what courts $d o$.

Contrast this with what the political branches of government typically "do." Political decisionmaking (at least as conceived by Sunstein and other neo-Madisonians, who discount the roles of rent-seeking and interest group "deals" in politics 215 ) is primarily decisionmaking about good results, indeed about results that inure to the common good. The political branches are not typically concerned with resolving existing disputes-this is the courts' job. They are concerned instead with creating prospective rules that can guide the resolution of future disputes and, if possible, prevent future disputes from occurring. Thus, political decisionmaking is not primarily concerned with rights (that is, entitlements to a particular outcome), but rather with the common good (that is, whether a particular outcome is or is not good social policy). ${ }^{216}$

It is inherent in the dispute-resolution role of courts, then, that they entertain and assess arguments about rights. It is not inherent, or at least is much less so, in the policymaking role of the political branches that they entertain and assess such arguments. The fact that courts unavoidably make decisions about rights, and thus make them with much greater regularity than do the political branches, casts substantial doubt upon any approach that, like the new judicial minimalism, commands courts frequently to defer to the political branches with respect to such decisions.

214. And the defendant has the same "right," although with respect to the defendant the "right" looks more like a "duty."

215. See, e.g., Sunstein, One Case at a Time, supra note 8, at 24-25 (arguing that legislation achieved through "power" rather than deliberation is illegitimate); Sunstein, Free Speech, supra note 8, at 241-52 (arguing that legitimate lawmaking stems from public deliberation); Sunstein, Partial Constitution, supra note 8, at 17-39 (arguing that reason is the only legitimate basis for political activity); see also, e.g., Deliberative Democracy (Jon Elster ed., 1998) (collecting essays defending deliberative democracy); Deliberative Democracy: Essays on Reason and Politics (James Bohman \& William Rehg eds., 1997) (same); Gutmann \& Thompson, supra note 180, at 45-46 (suggesting that interest group pressures cancel each other out).

216. This is not to say that the political branches never concern themselves with rights, or that they never should do so. A party who will be affected by a proposed rule can invoke arguments of entitlements, or rights, for or against that rule. For instance, a party who will be forced to pay a proposed tax can argue that her "right" to (a certain kind of) autonomy will be impaired by the tax. Such arguments may have weight, even decisive weight, in political decisionmaking. But they will exist alongside arguments about the common good-for example, an argument that the proposed tax will improve society by increasing the money available for necessary social services. The coexistence of, and interplay between, arguments of right and arguments about the common good is characteristic of politics. 1t is not, however, characteristic of adjudication. 
This command belies the fact that courts are more practiced in deciding about rights than the political branches are.

2. Rights, Continuity, and the Common Law. - Decisionmaking about rights thus is inherent in the adjudicative function of reasoned dispute resolution. To recognize this, however, is to leave open the question of where the rights assessed by courts come from. The answer in the AngloAmerican common law tradition is that they come primarily from previous court decisions. A court's assessment of the rights of the parties to a dispute before it is based upon-and, on a Dworkinian view, may even be seen to arise from ${ }^{217}$-courts' resolutions of prior disputes involving similar facts. In the common law tradition, moreover, each successive court decision progresses only incrementally from the prior decision or decisions upon which it is based. 1ndeed, sudden large leaps in doctrine would undermine the notion that the resolutions of particular cases proceed unavoidably and inevitably from the resolutions of previous ones. 1t would threaten the very notion of "rights."

The entirety of Sunstein's One Case at a Time, as its title suggests, is a celebration of this common law method of case-by-case, gradualist decisionmaking. ${ }^{218}$ But even Sunstein underappreciates the essential connection between common law gradualism and rights, an oversight that is amplified in the work of Michael Dorf, for whom the common law is too gradualistic. ${ }^{219}$ In our common law system, legal rights are products of gradualist decisionmaking. What is more, their character as rights is preserved by gradualism.

Our tradition generally denies the existence of legal rights that are not traceable in some way to a suitably pedigreed source. ${ }^{220}$ In pure common law cases, that source is prior case law; in cases involving statutes, it is the statute (however conceived) ${ }^{221}$ and prior case law; in cases involving

217. 1 am thinking particularly here of Dworkin's well-known "rights thesis," which holds that the "gravitational force" of precedents produces a "correct" result (and thus a "right" of one party to win) in subsequent cases. See Dworkin, Taking Rights Seriously, supra note 204, at 82-90. Dworkin later refined this idea into the notion of decisional law as a "chain novel," in which each court is constrained to decide cases in the way that best interprets and applies the import of past decisions. See Ronald Dworkin, Law's Empire 228-38 (1986) [hereinafter Dworkin, Law's Empire].

218. Cf. Sunstein, Legal Reasoning, supra note 8, at 62-100, 121-35.

219. See Dorf, supra note 11 , at 45 .

220. This is not to deny the viability of natural law or "incorporationist" theories of law, which give legal status to (some) norms thought to exist wholly or partially without dependence upon an existing authoritative source. 1 assume here only that our tradition requires, at least, that law be tied or accommodated to agreed-upon authoritative sources in some way-for example, in the holistic way that Dworkin posits, see, Dworkin, Law's Empire, supra note 217, at 226-28, or perhaps by "incorporation" as suggested by Jules Coleman. See Jules L. Coleman, Negative and Positive Positivism, 11 J. Legal Stud. 139, 160 (1982).

221. Different theories of statutory interpretation might rely on different types of sources, and might rely on them in different ways. One theory, for example, might make use of legislative history while another might not. 
constitutions, it is the constitution (again, however conceived) and prior case law. It is mostly impermissible in our tradition for a court to "declare" the existence of a "right" without at least some authoritative reference to these kinds of sources. Even in decisions often described (and frequently criticized) as having declared "new" rights-for example, MacPherson v. Buick Motor Co. in the common law realm ${ }^{222}$ and Griswold v. Connecticut in the constitutional realm ${ }^{223}$ - courts have taken pains to tie their decisions to prior cases, albeit sometimes unconvincingly.

This virtual prohibition against the ex nihilo "creation" by courts of "new" rights reflects, or perhaps is reflected by, the fact that case-by-case gradualism defines rights in the common law. A litigant does not have a right to a particular resolution of a dispute unless that right is supported by decisions in prior cases. Court decisions that depart radically from prior decisions thus cannot convincingly articulate common law rights; there is nowhere for such "new" rights to come from. Only gradualism maintains a close enough connection between rights articulated on new facts and rights recognized in prior cases. In the common law, continuity and rights are inseparable.

The continuity of the common law not only creates rights; it also maintains their status as rights. The distinctive character of rights is compromised if their existence depends too much on precise shadings of fact. Imagine, for instance, if Griswold v. Connecticut had been strictly limited to its facts in future decisions. The "right" first articulated in that case then would not have been anything approaching the breadth of "the right of privacy"; it would have been something much more narrow, perhaps "the right of married couples to use in their own homes contraceptive drugs or devices if prescribed by a licensed physician." Such a "right" hardly deserves the title; it is more like a curiosity or an anomaly.

A related point is that rights can scarcely be called "rights" if their recognition is relatively ephemeral. If the "right of privacy" first articulated in Griswold had been wholly repudiated, rather than reaffirmed and arguably expanded, eight years later in Roe v. Wade, ${ }^{224}$ it would be stretching things to call it a "right" at all.

The gradualism inherent in the common law insulates rights from arbitrary constriction and capricious disavowal. True, a right hastily declared and ill-supported by prior decisions may readily be limited or rejected by subsequent ones. ${ }^{225}$ But the same norms that deter courts from abruptly creating rights also deter courts from abruptly limiting or abandoning them. Just as common law rights emerge slowly, they change slowly and disappear slowly, too.

222. 111 N.E. 1050 (1916) (recognizing right of injured third party to sue in tort manufacturer of defective, but not inherently dangerous, product).

223. 381 U.S. 479 (1965) (recognizing constitutional "right of privacy" that protects married couples' choice to use contraception).

224. 410 U.S. 113, 153 (1973).

225. On this point, see infra Part V.A. 
Contrast this gradualistic quality of court-created rights with the abruptness and transience of many rights created in the political branches. The political branches are not bound to follow or even to respect precedent; they can create entirely new statutory or regulatory rights today and repeal them tomorrow. Politically created rights need not be grounded in the past, and, for that reason, they need not extend very far into the future.

The ephemeral nature of politically created rights is perfectly appropriate to the usual mission of the political branches, which is making policy, that is, pursuing the common good. The common good-and, perhaps more to the point, ideas about the common good-can change from year to year or even from day to day. Perhaps even more to the point, the majority coalition responsible for determining and acting to further the common good can change from election cycle to election cycle. From the standpoints of both efficacy and democratic legitimacy, it generally would be foolish to lock in the political branches to any sort of long-term commitments about legal rights.

But where the rights in question are rights against the majority, it would be foolish to subject them to fluctuations in majority interest or majority opinion. This point is slightly but crucially different from the usual one about foxes guarding henhouses. Even if the majority (or its representatives in the political branches of government) could be trusted to act in good faith in deciding issues of individual or minority rights, it still would be prisoner to the political way of doing things: unconstrained by the past and with little ability to constrain the future.

Their lack of constraint by the past means the political branches have difficulty articulating anything that sounds like a right against the majority. Such rights ultimately must come from somewhere other than the majority they stand against, and it is unclear what that source might be for the political branches, which have no system of precedent to draw from.

Their inability to constrain the future means not only that the political branches cannot guarantee that the "rights" they articulate will be truly durable (which is really just a restatement of the problem of lack of constraint by the past), but also that their decisions about rights will be skewed by the knowledge that those rights need not be durable. The political branches do not need to worry about the lasting implications of the rights they articulate, because they know that they (or their successors) can-without the necessity of justification-renege on those "rights" in the future if they turn out to be too troublesome. It is easy for Congress to refrain from enacting legislation that threatens free speech this year if Congress knows it can enact the same legislation next year. Worse, it is easy for Congress to bow to political pressures and enact that legislation this year if Congress knows that it (or its successor) can repeal the legislation next year. This is an underappreciated response to the Thayerian argument, which is echoed by Tushnet, that judicial review en- 
courages the political branches to shirk their duty of constitutional judgment by making the courts available to pass that judgment for them. ${ }^{226}$ The availability of a subsequent repeal of constitutionally questionable legislation-perhaps by a successor legislature made up of different members-is no less an "out" for irresponsible legislators than is the availability of judicial review.

The point is that there is a necessary and close relationship between continuity and rights, at least when "rights" means rights against the majority. Court decisionmaking is characterized by continuity; political decisionmaking is not. It stands to reason, then, that courts will be better decisionmakers about rights than the political branches will be.

3. Rights and Analogical Reasoning. - In the extensive treatment of analogical reasoning in his 1996 book Legal Reasoning and Political Conflict, Sunstein celebrates the fact that "analogical reasoning is focused on particulars, and it develops from concrete controversies." ${ }^{227}$ ln One Case at a Time, Sunstein defends judicial minimalism as "a sensible reaction to the limitations that judges know they face, not least in predicting the consequences of their decisions." 228 These two positions, however, are at odds with each other in an important sense.

As Sunstein has noted, a strength of analogical reasoning as a decisionmaking method is its grounding in factual context. ${ }^{229} \mathrm{~A}$ judge reasoning analogically compares the specific facts of a case to the specific facts of a prior case and asks whether they are similar in relevant respects. Of course, the judge must utilize some principle by which the relevant factual similarities can be determined, and by definition such a principle will transcend specific facts. But this principle itself comes from the facts of prior cases; it is a reason or justification connecting those facts with the prior cases' results. Put another way, a principle is the reason a particular result is justified by a particular set of facts. It is emphatically not an abstract, acontextual concept. ${ }^{230}$

Having extracted a principle from prior cases, the judge reasoning analogically then applies that principle only to her own case. She leaves it up to judges in future cases to decide whether that principle is wisely applied to different facts.

226. See Thayer, supra note 121, at 155-56; Tushnet, Taking the Constitution Away, supra note 7, at 57-58 (adopting Thayer's argument).

227. Sunstein, Legal Reasoning, supra note 8 , at 67.

228. Sunstein, One Case at a Time, supra note 8 , at 53.

229. See Sunstein, Legal Reasoning, supra note 8, at 62-100.

230. For an analogous proposition, see Dworkin, A Matter of Principle, supra note 209, at 2:

When political issues come to court . . they plead for decision that is at once discrete and principled. They must be decided at retail, in their full social complexity; but the decision must be defended as flowing from a coherent and uncompromised vision of fairness and justice ... Legal analysis, in this broad sense, is more concrete than classical political philosophy, more principled than political craft. 
Contrast, in these respects, the decisions produced by analogical reasoning with the decisions made by legislatures. ${ }^{231}$ First, although a legislature may be motivated to take action by specific problems or disputes, it is not required to make its decisions consistent with decisions it or its predecessors have made in the past. Thus the legislature has no need to identify something - a "principle"-by which consistency across decisions can be assessed. It has no need, that is, to examine prior decisions and identify the norms that justified those decisions in light of their facts. Freed from this necessity, the legislature can base its decisions on norms that are entirely acontextual and that, because of this acontextuality, may not work very well when applied to actual facts. In contrast, principles identified through analogical reasoning work well, by definition, when applied to at least some sets of actual facts: those of the precedents that produced the principle. "An [ ] advantage that courts have," Bickel wrote,

is that questions of principle never carry the same aspect for them as they did for the legislature or the executive. Statutes, after all, deal typically with abstract or dimly foreseen problems. The courts are concerned with the flesh and blood of an actual case. This tends to modify, perhaps to lengthen, everyone's view. It also provides an extremely salutary proving ground for all abstractions; it is conducive, in a phrase of Holmes, to thinking things, not words, and thus to the evolution of principle by a process that tests as it creates. ${ }^{232}$

Second, the operative concepts embodied in legislation, because they are acontextual, almost inevitably apply in cases beyond those envisioned by the enacting legislature. A court reasoning analogically decides that, on a particular set of facts $F_{1}, F_{2}$, and $F_{3}$, result $R$ obtains. The court does not decide whether result $R$ would obtain in the presence of additional fact $F_{4}$; nor does the court decide whether result $R$ would obtain in the absence of fact $F_{l}$. A legislature enacting a statute, however, typically decides that result $R$ obtains in the presence of facts $F_{1}, F_{2}$, and $F_{3}$, quite regardless of whether additional fact $F_{4}$ is present; it also decides that result $R$ does not obtain in the absence of fact $F_{l}$. A legislature, that is, decides many cases that are not "before it," and thus almost inevitably decides cases it has not carefully considered. ${ }^{233}$ But a court decides only the particular case before it and thus determines the consequences of only a single, finite set of facts.

231. I use the legislature here as the paradigm of a "political" branch. Much of what follows applies to the executive branch as well, but probably not all of it. Like the legislature (but unlike the courts), the executive is not typically constrained by "principle." But the executive often makes more particularistic decisions-that is, decisions affecting a smaller number of cases-than the legislature does.

232. Bickel, supra note 3 , at 26 .

233. For a more nuanced discussion of the difference between the decision embodied in a typical common law ruling and that embodied in a typical statute, see generally Peters, Adjudication, supra note 15 , at 361-66. 
Thus it is strange for Sunstein (and Michael Dorf, who takes a similar approach) to celebrate the particularism and contextuality of analogical reasoning while at the same time worrying about "the limitations that judges know they face, not least in predicting the consequences of their decisions." 234 The limitations judges face in this respect seem considerably less significant than those faced by legislators, both because judges' decisions tend to be better grounded in actual facts and because the consequences of their decisions tend to be more closely tethered to the actual facts upon which those decisions are based. A court usually does not decide what would be best in the abstract; it decides what is the right result on the facts of a particular case. And a court usually limits the scope of its decision to those facts, refusing to decide cases whose facts are not before it. Legislative decisionmaking typically shares neither of these characteristics.

All of which suggests that courts generally will be better than legislatures at making decisions that benefit from close attention to factual context. Tushnet disagrees, asserting that " $[t]$ his contrast between courts and legislatures is so overstated as to be worthless."235 First, Tushnet points out, "[l]egislatures respond to real"-that is, factually specific"human problems too."236 Tushnet offers the example of "Megan's Laws," statutes requiring disclosure of a convicted sex offender's residence in a community, enacted as legislative "respon[ses] to the abduction and murder of a [particular] child by a [particular] convicted sex offender." ${ }^{237}$

But this example merely supports my point. Megan's Law, inspired by an especially compelling case, is likely to have many consequences in other cases that were not foreseen by the legislature that enacted it. A law that seems like good policy when applied to a murderer or a serial pedophile may not seem like good policy when applied, say, to an eighteen-year-old woman convicted of the statutory rape of her sixteen-yearold boyfriend. When such unforeseen consequences potentially affect not just policy but rights-in the case of Megan's Law, perhaps the constitutional rights to privacy or due process of law, or the constitutional protection against ex post facto laws-then it makes little sense for a court faced with such consequences to defer to the "judgment" of a legislature that did not anticipate them.

On the other side of the coin, Tushnet asserts somewhat ambiguously that "courts can respond to general, abstract concerns just as legislatures do."238 1 can think of three more-specific points Tushnet may have

234. Sunstein, One Case at a Time, supra note 8, at 53. Dorf's proposal of "provisional adjudication" seeks to address similar concerns about the predictive fallibility of the Court. See Dorf, supra note 11, at 60-69.

235. Tusbnet, Taking the Constitution Away, supra note 7 , at 69 .

236. Id.

237. Id.

238. Id. 
in mind here. First is simply the fact that courts must speak and think in terms of principles-a fact that, as I argue above, actually supports a preference for judicial decisionmaking on matters of rights. Second, Tushnet may have in mind the fact that courts sometimes lay down broad rulesas with asbestos lawsuits, where, as Tushnet notes, "the courts [have] devised quite elaborate procedures to sort out the claims." ${ }^{239}$ I explain in Part IV why this kind of procedurally nonminimalist behavior by courts can threaten both the democratic legitimacy and the quality of their decisionmaking (although of course there may be countervailing factors of efficiency, predictability, and the like weighing in favor of such broad rules). In any event, the kinds of broad general rules set by courts in asbestos litigation certainly are exceptional rather than typical.

Third, Tushnet may have in mind the fact that courts sometimes act procedurally somewhat like legislatures, with the participation of a broad spectrum of potentially affected parties. As he explains, " $[\mathrm{m}]$ odern procedural devices . . . sometimes convert court hearings into versions of a modern town meeting." ${ }^{40}$ This is true, and to a large extent it is a trend to be encouraged, as I have argued elsewhere. ${ }^{241}$ But it is entirely beside the point here, which is that courts typically decide issues in particular contexts rather than in the abstract-a point that holds regardless of who, or how many, are participating as litigants or amici in the decision of that particular issue.

Tushnet's objections aside, then, there remains strong reason to believe that courts typically are better than the political branches at making fact-sensitive decisions. It may be that most government decisions, not just those involving individual rights, are fact-sensitive in this way. If so, then the new minimalists' functional hierarchy of legislature over court may be backwards with respect to many kinds of decisions. 1 doubt, however, that even a juricentric approach can take us this far; as I explain below, there are other functional considerations besides the importance of factual context that come into play in government decisionmaking, and many of those considerations weigh in favor of political rather than judicial hegemony. In any case, my suggestion for present purposes is only that decisions about rights tend to benefit from close attention to factual context and thus generally are better suited to resolution by adjudication than by political decisionmaking.

Let me support this suggestion with a simple but revealing anecdote. I often poll the students in my Constitutional Law course to see how many of them believe in the existence of a constitutional "right of privacy." Most of them say they do. Then I ask the students to explain the result demanded by a "right of privacy" in a short series of cases: Griswold

239. Id.

240. Id. (citing Stephen C. Yeazell, Intervention and the Idea of Litigation: A Commentary on the Los Angeles School Case, 25 UCLA L. Rev. 244, 244 (I977)).

241. See Peters, Adjudication, supra note I5, at 4I7-I9. 
v. Connecticut, ${ }^{242}$ Roe v. Wade, ${ }^{243}$ and Bowers $v$. Hardwick. ${ }^{244}$ Many of them are not sure what some or all of the results should be. Of course, many of them disagree sharply with others over the implications of a "right of privacy" for each particular case.

The point of this academic parlor game is to demonstrate what experienced lawyers and constitutional scholars already know: The content of rights is inherently contextual. ${ }^{245}$ Simply declaring the existence of a "right of privacy" does not say very much. (1t does say something; there is an amorphous core of meaning to a "right of privacy" that allows most lawyers at least to identify cases in which it might be relevant. This fact is revealed by the phenomenon that none of my students ever protests that the right of privacy simply is not relevant to Griswold, Roe, or Bowers.) But one has to point to particular sets of facts to begin to understand what a "right of privacy" might actually entail.

To bring things closer to the subject of this Article, imagine that, preBowers but post-Griswold and Roe, a bill is introduced in a state legislature that would criminalize homosexual sodomy. Legislator Smith rises and declares that the legislature should not pass the bill without first determining that it does not infringe the constitutional "right of privacy." How will he and his colleagues go about conducting this inquiry? Probably they will offer a series of hypothetical situations in which the statute might apply, asking with respect to each situation whether the "right of privacy" has been infringed. But there will always be a hypothetical case they miss. Perhaps they will not envision arrests in the bedroom of a defendant's home, triggered by a tip from a nosy neighbor and carried out by a cadre of armed police officers. The "right of privacy" that the legislature is confident is not infringed by prohibiting, say, sexual contact in an adult movie theater or in a bathhouse may in fact be infringed by the statute as applied to other, unenvisioned circumstances.

Of course, maybe that hypothetical case never arises in the real world. But if it does, it seems silly for the court deciding it to defer to the legislature out of respect for "the limitations that judges know they face, not least in predicting the consequences of their decisions." 246 The consequences of the decision faced by the court are quite clear-clearer, at least, than they may have been to the legislature, which might not even have envisioned the case the court must now decide.

lt seems, then, that decisions about rights benefit significantly from being made with reference to particular facts. True, one might object that this argument proves too much. Virtually every legislative act carries potential consequences that the legislature did not envision and may not

242. 381 U.S. 479 (1965).

243. 410 U.S. 113 (1973).

244. 478 U.S. 186 (1986)

245. See, e.g., Dorf, supra note 11 , at 53 (" $[T]$ he specification of rights can only proceed in concrete contexts within which particulars matter.").

246. Sunstein, One Case at a Time, supra note 8, at 53. 
have endorsed, whether the statute implicates individual rights or not. Should a court always refuse to implement these unforeseen consequences? ${ }^{247}$ Conversely, should a court always defer to foreseen applications of a statute, even if those applications seem to infringe individual rights?

These rhetorical questions miss the point of the instant comparison between analogical reasoning and legislative decisionmaking. The point is not to demonstrate that courts are functionally superior decisionmakers to legislatures in most or every context in which decisions can be made. The point, rather, is to demonstrate that courts are functionally superior decisionmakers in one context in which they are charged with making decisions in our political system: the context of individual rights. The new minimalists do not dispute that courts ultimately must make decisions about individual rights in our system, particularly about constitutional rights. ${ }^{248}$ Their thesis is that, in making those decisions, courts should defer (to some degree, in some cases) to the judgment of the legislature out of concern for their own cognitive limitations. My analysis thus far has suggested only that the cognitive limitations faced by courts in such cases are no greater, and probably are less significant, than the cognitive limitations faced by legislatures when enacting the statutes at issue in them.

In any event, the decisionmaking advantage enjoyed by courts over legislatures does not extend to all (or even to most) decisions that are highly contextual. Courts, after all, must operate according to principles, and this requirement can impose significant limitations. Some decisions are in effect so fact-dependent that it is difficult or impossible to extract a principle from them, or to apply a principle to them. An example is the decision, made every year by Congress and the Administration by means of appropriations bills, of how to budget the federal government. A court could never effectively decide this issue, because it involves no principle that can be extracted from prior similar decisions and applied meaningfully in the case at hand. The task of reasoning by analogy from one year's budget to the next would be, in one of my wife's favorite phrases,

247. The answer to this seemingly rhetorical question may be more complex than at first it appears. See Christopher J. Peters, Statutory Interpretation and the Default Position 1-6 (Aug. 9, 2000) (unpublished manuscript, on file with the Columbia Law Review). Suffice it to say that there may be cases in which a court should indeed refuse to implement consequences of a legislative enactment that apparently were not foreseen by the enacting legislature.

248. For example, Sunstein endorses "ambitious [ ]" recognition of rights by the Court on tbose "relatively rare occasion[s]" where the Court has "encounter[ed] the basic problem for a period of years." Sunstein, One Case at a Time, supra note 8, at 170 . Similarly, Dorf sees a role for the Court in "the articulation of fundamental . . . values." Dorf, supra note 11 , at 79 . On the other hand, abolitionists like Tushnet do indeed dispute this proposition. And opponents of judicial supremacy like Tushnet and Burt, and perhaps discursivists like Devins and Katyal, dispute that courts must finally decide issues of constitutional rights. See supra Part 1.B.3.c (discussing Tushnet); supra Part 1.B.3.a (discussing Burt); supra Part 1.B.3.b (discussing Devins and Katyal). 
"like herding cats." 1t is an example of what Lon Fuller called a "polycentric" problem, ${ }^{249}$ and of what Hart and Sacks called a "dispute [that] is not susceptible of a reasoned solution."250 Only the political branches, with their freedom from principle and their amenability to bargaining, can effectively tackle such problems.

Decisions about rights, however, will rarely or never be polycentric in this way, probably because rights depend for their very existence on some principle that can be applied consistently across cases. Decisions about rights will usually or always be matters both of principle and of context. As such, they will be amenable to the process of analogical reasoning, a process typically employed by courts but not legislatures. ${ }^{251}$ At least in the realm of individual rights, there is no convincing reason for a court to defer to a legislature on the ground of cognitive disadvantage.

\section{The Juricentric Case for Procedural Minimalism}

The case for the new judicial minimalism appears to be based on two premises: first, that political decisionmaking is significantly more legitimate in a democratic sense than judicial decisionmaking, and second, that judicial decisionmaking is not significantly more efficacious than political decisionmaking in matters of individual rights. The previous two Parts have called both premises into question. Like political decisionmaking, adjudication is both a participatory and a representative process. Indeed, it is often more participatory than political decisionmaking, and while it is not representative in the majoritarian sense, it is representative in the way that might matter most: in the incentives it creates for representatives (precedent-setting litigants) to act in the best interests of their constituents (future bound litigants and conforming nonlitigants).

Moreover, adjudication is a particularly apt process for making decisions about individual rights. The countermajoritarian advantage held by courts is no less advantageous for being a cliché. The relative opacity of judicial decisionmaking promotes true deliberation, especially in comparison to the increasing tumult of politics in the age of mass media. And the common law method, with its gradualism, contextualism, and respect for principle, is better suited to making decisions about rights than the spontaneity, abstractness, and pragmatism that characterizes political decisionmaking.

249. Fuller, supra note 13 , at $394-404$. Note again the distinction between "polycentric" problems and what I have called here "policentric" approaches to judicial review.

250. Henry M. Hart, Jr. \& Albert M. Sacks, The Legal Process 645 (William N. Eskridge, Jr. \& Philip P. Frickey eds., 1994).

251. Ronald Dworkin makes a similar point. See Dworkin, A Matter of Principle, supra note 209, at 24 (" $[N]$ o claim of right is sound if it cannot stand the test of hypothetical counter-example. But the technique of examining a claim of right for speculative consistency is a technique far more developed in judges than in legislators or in the bulk of the citizens who elect legislators."). 
When the twin premises of the new minimalism are undermined, we are left with a picture of the American judiciary-with the Supreme Court at its apex-as more than just the handmaiden of deliberative democracy. The Court is an active and crucial participant in the process of deliberative democracy. It is just as deliberative in its own way as the political branches, and often it is more deliberative, especially with respect to individual rights. And it is significantly democratic, too, although not majoritarian. The Court thus can be understood as a coequal institution of deliberative democracy, with the emphasis on the deliberative component.

Taking this juricentric view of the Court, however, still leaves an important place for some form of judicial minimalism. As 1 contend below in Part V, my critique undermines the case for substantive minimalismthat is, for deference by the Court to the political branches in matters of individual rights, in the form of a reluctance to overturn the results of democratic politics. But the critique preserves, and even strengthens, the case for procedural minimalism-for narrowness and shallowness in decisionmaking, whether the decisions validate or invalidate the results of democratic politics. Procedural minimalism is an important component of both the accountability and the functionality of the Court's decisionmaking.

\section{A. Procedural Minimalism and Judicial Legitimacy}

Procedural minimalism-narrowness and shallowness in judicial decisionmaking - is defensible less as a means of preserving and bolstering the accountability of political decisionmaking than as a means of preserving the accountability of judicial decisionmaking. This conclusion follows from the description of adjudication as a representative process outlined in Part 11.252

In Part Il, I noted that court decisions routinely bind subsequent litigants and conforming nonlitigants, whose interests can be seen to be represented by the litigants participating in a precedential decision. The more similar the facts of the precedential case and the subsequent case, the more similar the interests of the representative and subsequently bound litigants are likely to be-and thus the greater the likelihood that the representative litigants will adequately represent the subsequent litigants' interests. The broader the rule announced by a court in deciding a case, however, the broader the spectrum of subsequent litigants and conforming nonlitigants who will be bound by that rule-and thus the looser the ties of interest between the representative and bound parties.

For instance, the Supreme Court's declaration in Brown v. Board of Education that "[s]eparate educational facilities are inherently une-

252. For a more complete version of this argument, see Peters, Adjudication, supra note 15 , at $401-11$. 
qual"253 necessarily bound school systems that may have been dissimilarly situated in material ways to that of Topeka, Kansas, the defendant in the case. (One could argue that northern school districts afflicted primarily by de facto, not de jure, segregation were materially dissimilar in this sense-an argument the Court ultimately accepted, but not without some consternation. ${ }^{254}$ ) But the interests of these dissimilar school districts, by virtue of their dissimilarity, were not adequately represented by the Topeka Board of Education in Brown. Because the Topeka Board had engaged in de jure discrimination, its interest in that case was to maintain the Plessy rule that segregated facilities, whether or not segregated intentionally, do not automatically violate the Equal Protection Clause. The Topeka Board had no interest in preserving a distinction between de jure and de facto segregation. The broad "separate-is-unequal" rule announced by the Court, however, arguably bound other school districts that did have an interest in preserving that distinction. These other school districts were potentially bound by a rule that neither they nor any reliable representative of their interests had helped to create.

In this way, a lack of procedural minimalism, in the form of the articulation of broad judicial rules, threatens the legitimacy of interest representation in adjudication. Interest representation only works when the interests of subsequent litigants and conforming nonlitigants are coextensive with those of the participating litigants in material ways. But this is unlikely to be the case when a court announces a broad rule, because in doing so the court necessarily binds subsequent litigants and conforming nonlitigants with interests distinct from those of the participants.

This challenge to the accountability of adjudicative decisionmaking is a function of a lack of narrowness (that is, of width) in judicial decisionmaking. But it is worth noting that a lack of shallowness (depth) can compromise accountability in precisely the same way. Indeed, depth pro-

253. 347 U.S. 483,495 (1954).

254. In Swann v. Charlotte-Mecklenburg Board of Education, the Court upheld the district court's plan of busing and gerrymandering of school districts to remediate the continuing de facto effects of historical de jure segregation. 402 U.S. 1, 31-32 (1971). In Keyes $v$. School District No. 1, Denver, Colorado, the Court held that a system-wide remedy might be appropriate in a school district that had never mandated segregation by statute, even though de jure segregation had been established with respect to only a small portion of the district. 4 I3 U.S. 189, 208 (1973). The concurrences of Justices Powell and Douglas in Keyes advocated abandoning altogether the distinction between de facto and de jure segregation. See 413 U.S. at 214-15 (Douglas, J., concurring); 413 U.S. at 219-36 (Powell, J., concurring). In subsequent cases, however, the Court restricted judicial authority to the remediation of the demonstrable effects of de jure segregation. See Milliken v. Bradley, 418 U.S. 717, 752-53 (1974) (holding that district court lacked power to order interdistrict remedy absent proof of interdistrict de jure violation or interdistrict effects of de jure violation); Pasadena City Bd. of Educ. v. Spangler, 427 U.S. 424, 434-35 (1976) (holding that district court's remedial authority was exhausted once school district implemented racially neutral student assignment plan, despite continuing de facto segregation); Missouri v. Jenkins, 515 U.S. 70, 101-02 (1995) (rejecting district court remedial plan designed to attract nonminority students from other districts). 
duces width. It is difficult to imagine a court opinion that is deeply reasoned without, by virtue of the very depth of its reasoning, also setting out some sort of broad rule that will impact future cases.

Suppose, for example, that a court strikes down as unconstitutional a particular government activity-say, the maintenance of a males-only public military college-but gives no reason for doing so other than simply saying, "This particular policy on these particular facts violates the Equal Protection Clause." Such a decision would be both very shallow and very narrow; it would have no necessary implications for any other case, unless another case arises bearing virtually identical facts to those at issue in the precedential case.

But suppose, on the contrary, that the court invalidates the malesonly policy in a deeply reasoned opinion elucidating first principles of gender equality under the Equal Protection Clause. (This is what the Supreme Court actually did in its $V M I$ decision. ${ }^{255}$ ) Even if the court purports to act narrowly in doing so-by expressly limiting the precedential force of its decision to the particular facts of the case, as the VMI Court did-the actual impact of the decision will be inescapably broader than those particular facts. This will hold true especially among lower federal and state courts, which will properly be reluctant to ignore the grounds upon which a Supreme Court decision has been rendered. The deep reasoning underlying the decision, precisely because it is deep reasoning, will have applications in other gender equality cases. In effect, the reasoning will operate as a sort of rule, influencing the decisions of future cases to which that reasoning is relevant. And that reasoning will be relevant in a broad spectrum of cases involving government-imposed distinctions between men and women, not just in cases with facts very similar to those of $V M I$.

In other words, depth and width in judicial decisionmaking are qualitatively, if not necessarily quantitatively, the same thing. There really is no category consisting of decisions that are both very "deep" and very "narrow"; 256 at best there are some deep decisions that are less wide than others. A decision like that in VMI, which is deeply reasoned but expressly limited to its facts, is somewhat narrower than a decision like Brown $v$. Board of Education, which is both deeply reasoned and explicitly wide in scope (" $[s]$ eparate educational facilities are inherently unequal" ${ }^{257}$ ). Both types of deep decision, however, are necessarily wider than a decision that is both very narrow and very shallow, such as that in United States v. Lopez, in which the Supreme Court narrowly invalidated a

255. See United States v. Virginia, 518 U.S. 515, 556-58 (1996); see also Sunstein, One Case at a Time, supra note 8, at 163-71 (discussing $V M I$ ).

256. Sunstein, however, thinks that such a category exists. See Sunstein, One Case at a Time, supra note 8 , at 17 (describing Court decisions that he categorizes as both deep and narrow).

257. Brown, 347 U.S. at 495; see also Sunstein, One Case at a Time, supra note 8, at 17. 
particular statute under the Commerce Clause without providing a deeply theorized reason for doing so. ${ }^{258}$

To return to the primary point: Procedural minimalism-that is, narrowness and shallowness in decisionmaking, without regard to the substance of the decision itself-is a necessary prerequisite of the democratic legitimacy produced when litigants in a precedential case serve as interest representatives of future litigant-subjects or of conforming nonlitigant-subjects. Importantly, this justification of minimalism is juricentric, not policentric; it rests not on concerns for the legitimacy of the political branches, but on concerns for the legitimacy of the Court itself.

\section{B. Procedural Minimalism and Judicial Competence}

Procedural minimalism is a necessary component of the Court's accountability; it is also a necessary component of the Court's unique competence in matters of individual rights. As I explained in Part III, the very concept of legal rights supposes both a gradualistic progression of decisions from which rights can arise and a concrete platform of facts upon which rights can be fixed.

When the Court renders a broad decision-one with substantial binding effect in a variety of factual contexts that otherwise might seem materially distinguishable-it acts in that respect like a legislature passing a statute. The impact of its decision inevitably will be felt in factual situations the Court (and the litigants) did not envision, or in any event did not carefully consider. If, as I suggested above, rights are best articulated in concrete factual circumstances, broad decisions by the Court forfeit

258. See 514 U.S. 549 (1995); see also Sunstein, One Case at a Time, supra note 8, at 17. Lopez illustrates that in a sense the question of a decision's minimalism-particularly its narrowness-is always open, because subsequent courts may interpret and apply an apparently narrow precedent broadly, or an apparently broad precedent narrowly. The former may have occurred recently in United States $v$. Morrison, in which the Supreme Court treated Lopez as "the proper framework for conducting the required analysis" and invalidated the Violence Against Women Act as exceeding Congress's Commerce Clause power. $120 \mathrm{~S}$. Ct. 1740,1749 (2000). 1t is possible that Morrison signals a willingness, on the part of a current majority on the Court, to read Lopez broadly, transforming its seemingly fact-specific reasoning into a set of tests or rules to be applied in dissimilar cases. 1 for one would be hesitant to draw this conclusion, since the statute invalidated in Morrison was in many respects quite similar to the statute invalidated in Lopez. Both, for instance, were criminal statutes touching on areas (education in Lopez, domestic relations in Morrison) traditionally regnlated by the states and in which there was no clear indication of state regulatory incompetence. But even if Morrison foreshadows a broad reading of Lopez, the relative narrowness (and shallowness) of Lopez is preferable from a legitimacy standpoint to a broader and deeper opinion, because it allows the parties in future cases like Morrison more freedom to urge factual distinctions, and it allows the court more freedom to adopt them-even if it chooses not to do so. Put more generally, the fact that courts in subsequent decisions may "expand" a seemingly minimalist decision does not mean they inevitably will do so, and the more minimalist the original decision, the more freedom the parties and the court will have in subsequent cases to resist expansion. 
much of its natural advantage over the political branches in matters of rights. ${ }^{259}$

Thus Sunstein is correct after all that "minimalism is a sensible reaction to the limitations that judges know they face, not least in predicting the consequences of their decisions." 260 There may be little or no reason to think that the Court is better than the political branches at making predictive decisions about rights (as opposed to decisions grounded in immediate, obvious facts). Thus there may be little or no reason for the Court, in rendering a broadly binding decision, to preempt the ability of the political process to take the first stab at applying rights to new circumstances.

This may be especially true in areas where "the relevant facts are in flux and changing very rapidly, and the consequences of current developments are hard to foresee," and in areas where "the legally relevant [moral] values are ... in flux and not at all simple to sort out."261 Areas of factual or moral "flux" are areas in which seemingly small distinctions between one case and another can demand entirely different types of resolutions. In areas of flux, a seemingly broad right might entail very different results in slightly different cases, or it might apply in one case but not in another. ${ }^{262}$

To express skepticism about whether the Court is better than the political branches at making predictive judgments about rights, however, is not to concede that the Court is worse at making such judgments. The Court's insulation from majoritarian pressures ${ }^{263}$ and its characteristically

259. But perhaps not all of that advantage. The Court's relative insulation from majoritarian politics and its relatively deliberative decisionmaking procedures might preserve some advantage over the political branches in decisions about rights, even absent the gradualism and fact-specificity of the common law method. See supra Parts III.A and III.B.

260. Sunstein, One Case at a Time, supra note 8 , at 53.

261. Id. at 174 .

262. Sunstein illustrates factual flux with, inter alia, Reno $v$. $A C L U$, in which the Court relied on narrow vagueness grounds to strike down provisions of the Communications Decency Act that prohibited the "knowing" transmission of "obscene or indecent" material to minors. 521 U.S. 844, 859, 874 (1997). As Sunstein contends, this procedural minimalism was appropriate because the area in question is in factual flux: Broad recognition of something like a "right to speech on the Internet" might foreclose future legislative intervention in response to new technological advances or to unanticipated dynamics in the nascent, constantly changing technology market. See Sunstein, One Case at a Time, supra note 8 , at $172-205$.

Sunstein illustrates moral flux with the Court's recent assisted suicide decisions. See id. at 75-116. As he notes, " $[t]$ he 'right to die' might be asserted in many diverse circumstances," and the applicable moral considerations might differ subtly but significantly with respect to each. Id. at 79 . Given the subtle and complex moral differences across the many possible factual scenarios, it would be unwise for the Court to render a blanket rule allowing states to prohibit assisted suicide; indeed, the Court has declined to do so. See Vacco v. Quill, 521 U.S. 793, 807-09 (1997); Washington v. Glucksberg, 521 U.S. 702, 735-36 (1997).

263. See supra Part 1II.A. 
deliberative decisionmaking methods ${ }^{264}$ give it an advantage over the political branches, whether or not the decisions it makes involve prediction. Given the admittedly lingering doubts about the Court's legitimacy relative to that of the political branches, ${ }^{265}$ however, and especially given the costs attendant to changes in the status quo, it probably makes sense for the (predictively fallible) Court to defer, by means of procedural minimalism, to the (predictively fallible) political process.

For these reasons, Sunstein's brand of procedural minimalism is more appealing than some more modest versions, including Fallon's, Dorf's, and the discursivist variety advocated by Katyal. Fallon is wary of deep reasoning but sanguine about doctrinal "tests" that apply across constitutional cases. ${ }^{266}$ Fallon's doctrinal tests, bowever, amount to broad rules meant to apply in a variety of cases that otherwise might seem factually distinct. As such, they demand the kind of prediction about the application of rights that the Court might not be especially good at. Dorf eschews fact-specific judicial application of rights altogether in favor of a regime in wbich the Court articulates fundamental constitutional values in a general way, leaving the details to be filled in by the political branches at the national or state level. ${ }^{267}$ Like Fallon's doctrinal tests, however, Dorf's fundamental values risk the fallibility inherent in application to many unforeseen cases (although it is probably true that decisions about rights cannot be made without drawing upon some principle that applies across cases ${ }^{268}$ ). More troublingly, they imply the uprooting of the judicial articulation of rights from the firm soil of particular facts, and thus the dilution of a chief advantage enjoyed by the Court over the political branches in making decisions about rights. ${ }^{269}$ The same objection applies to Katyal's suggestion that judges freely indulge in "advicegiving" about policies and facts not before the Court, ${ }^{270}$ although to the extent

264. See supra Part III.B.

265. See supra Part I.C.

266. See supra Part I.B.1; Fallon, supra note 11, at 106-41.

267. See supra Part I.B.2; Dorf, supra note 11, at 74-83; Dorf \& Sabel, supra note 84, at 388-418, 444-69.

268. See supra Parts III.C.2-3.

269. In discussing these issues with me, Professor Dorf has suggested that under bis approacb, courts (including the Supreme Court) would continue to be constrained, presumably by justiciability doctrines, to make decisions about core values in the context of particular facts. The political branches, however, particularly at the state and local level, would be relatively free to determine bow best to implement those values-that is, to remediate violations of them. Understood this way, Dorf's approach is consistent with procedural minimalism, although it is perhaps open to the objection that constitutional values articulated in such a contextually confined way hardly deserve to be called "core" or "fundamental" in any meaningful sense.

270. Katyal, supra note 108, at 17I0; see also supra notes $109-111$ and accompanying text. 
judges can accomplish this through nonbinding dicta the objection is not so strong. ${ }^{271}$

Narrow judicial decisionmaking, especially in areas wrought with factual or moral uncertainty, thus is defensible not as a response to the supposedly superior competence of the political branches in making predictive judgments, but simply as a means of reducing the risk of judicial error in making such judgments. Combined with the threat to the representative legitimacy of adjudication posed by broad or deep judicial decisions, the apparent connection between such decisions and a heightened risk of predictive error comprises a fairly compelling juricentric case for procedural minimalism.

\section{Procedural Minimalism and Justice Scalia's Rule-Based Formalism}

As 1 have argued more extensively elsewhere, 272 the juricentric case for procedural minimalism threatens one of the central jurisprudential tenets of Justice Antonin Scalia, perhaps the current Supreme Court's most intellectually influential member. Justice Scalia has argued off the bench in favor of broad judicial rules, and in his judicial opinions he has tended to practice what he preaches. In a frequently cited law review article, Justice Scalia has made a forceful case for a "law of rules," a jurisprudential approach by which appellate courts (and particularly the Supreme Court) presumptively decide cases broadly, according to "clear, general principle[s] of decision." 273 In that article, Scalia catalogues what he believes to be the chief benefits of broad rules: avoidance of judicial discretion, the like decision of like cases, and the promotion of predictability in the ordering of private affairs. ${ }^{274}$ Eric Segall has shown convincingly that Scalia's rule-based formalism is not merely academic, but has in fact been a fairly consistent feature of his judicial opinions, more consistent even than his (closely related) fondness for textualism. ${ }^{275}$

271. Neal Devins's brand of discursive minimalism is not so obviously open to this objection, as it seems to focus less on "giving advice" through dicta than on providing principled reasons for decisions the Court makes. See Devins, supra note 96, at 1990-91. Providing principled reasons necessarily adds depth to an opinion, and in this respect can have extradecisional effects similar to those produced by a wide decision. See infra notes 309-314 and accompanying text. But providing principled reasons also is part and parcel of what courts do in deciding cases and, more to the point, of what gives courts an advantage in making decisions about rights. See supra Part lll.C.

272. See Peters, Adjudication, supra note 15, at 401-11.

273. Scalia, Law of Rules, supra note 16, at 1179.

274. See id. at $1178-80$.

275. See Eric J. Segall, Justice Scalia, Critical Legal Studies, and the Rule of Law, 62 Geo. Wash. L. Rev. 991, 1005-20 (1994). Of course, six years and quite a few Scalia opinions have come and gone since Segall conducted his analysis, but 1 have no sense that Justice Scalia has radically altered his judicial approach during that time span. For Justice Scalia's most recent academic statement of his textualist philosophy, see Scalia, Matter of lnterpretation, supra note 6 . 
Justice Scalia's rule-based formalism, which calls for the rendering of wide holdings and opinions, is of course unabashedly nonminimalist. As such, if we take a juricentric approach to adjudication (and particularly to judicial review), we have strong reason to challenge this aspect of Scalia's philosophy. Turning the decisions of particular cases into occasions for the fashioning of broad rules, as Scalia advocates, raises a legitimacy problem for the Court, because it involves the decision (or at least the attempted decision) of issues not directly before the Court and thus the binding (or attempted binding) of dissimilar future litigants and conforming nonlitigants. When the nexus of similarity between litigantlawmakers and nonlitigant-subjects is attenuated in this way, the legitimacy of binding those nonlitigant-subjects becomes attenuated as well. This effect should be particularly troubling to Justice Scalia, who justifies his formalism and related textualism partly by reference to values of democratic legitimacy. ${ }^{276}$

As we have seen, the rendering of broad judicial rules also compromises the unique advantages enjoyed by courts with respect to the decision of cases on particular facts, advantages that are particularly salient in cases involving rights. When the Court renders a broad rule, it acts like a legislature, resolving or attempting to resolve ahead of time disputes arising from facts with which it is not directly familiar. The Court enjoys no special expertise in making such predictions, and thus there is less reason to allow the Court (rather than the political branches) to make them.

Of course, these arguments against Justice Scalia's rule-based formalism can only provide reasons against rendering broad decisions. Those reasons may not always, or often, be decisive; they may at times be outweighed by the reasons in favor of broad rules. Moreover, a judge or court might even take a particularistic, case-by-case approach to the question of whether to be minimalist, weighing in each case the advantages of minimalism against the advantages of broad rules. ${ }^{277}$ Thus the juricentric case for procedural minimalism at most seems to shift presumptions-away from Justice Scalia's presumption in favor of broad rules and toward the minimalists' presumption in favor of narrow and shallow decisionmaking. In any given case or type of case, this presumption might reasonably be overcome by countervailing considerations.

276. See Scalia, Law of Rules, supra note 16, at 1179-80 (connecting formalism to democratic value of constraining judicial discretion); Scalia, Matter of Interpretation, supra note 6 , at 23-25 (connecting formalism, and particularly textualism, to democratic values).

277. This seems roughly to be the course advocated by Sunstein, who suggests that " $[t]$ he choice between minimalism and the alternatives depends partly on pragmatic considerations." Sunstein, One Case at a Time, supra note 8, at 56. 


\section{The Juricentric Case Against Substantive Minimalism}

To the extent, then, that the new minimalists prescribe procedural minimalism-narrow and shallow decisionmaking that nonetheless involves fully and fairly deciding the case before the Court-this prescription is supported by a juricentric approach, even if it is not well supported by the new minimalists' problematic policentrism. But the new minimalists propose substantive minimalism as well-that is, some degree of presumptive avoidance by the Court of invalidating challenged government action, whether by upholding the action on the merits or by avoiding decision of the constitutional issue. Sunstein, for example, urges the Court to be "wary of recognizing rights . . . amid complex issues of fact and value." 278 Richard Fallon endorses the application of deferential "suspect-content" tests in areas characterized by "reasonable disagreement."279 And Michael Dorf proposes that the Court should "give . . . [some] deference to state policies that arguably infringe constitutional rights," and should "permit some doctrinal disagreements among the lower courts to go unresolved in order to discern the practical consequences of different legal regimes."280

My arguments in Parts 11 and 11 go a long way towards undermining the case for substantive minimalism. If in fact the Court acts with significant democratic legitimacy in its own right, and if in fact it tends to be more competent to decide issues of constitutional rights than the political branches, then there is little reason for the Court to defer to the political branches in making decisions about rights. And unlike with procedural minimalism, there are no affirmative juricentric reasons for the Court to engage in substantive minimalism. Because substantive minimalism does not implicate the width or depth of a decision, it cannot be supported as necessary to preserve the representative legitimacy or decisionmaking competence of the Court. Understanding adjudication as a process of participation and representation suggests that Court decisions about rights legitimately bind the litigants and those similarly situated to them; recognizing the special competence of the Court to make gradualistic, fact-specific decisions reduces concerns for potential error in recognizing rights on the facts of a particular case.

Even given the juricentric picture of the Court as significantly representative and specially competent, however, there remains a potentially compelling reason for endorsing substantive minimalism in cases involving rights. It might be thought that such decisions, when made by the Court, are significantly more permanent, or durable, than when made by the political branches. If erroneous Court decisions involving rights are significantly harder to change than erroneous political decisions, then the cost of judicial error-if not the risk of that error-might exceed the

278. Id. at 76 .

279. Fallon, supra note 11 , at $88-90$.

280. Dorf, supra note 11 , at 10-11. 
cost of political error in issues of rights. (Error cost, after all, is a function of both the frequency of error and the magnitude of error.) On this view, substantive minimalism-judicial reluctance to overturn political decisions affecting rights-might make sense after all.

I doubt my juricentric approach can provide a complete and decisive refutation of this "relative durability" argnment. But my approach does suggest important weaknesses in the argument-weaknesses that, combined with the analysis underlying the juricentric approach outlined in Parts II and 1II, in my view shift to the minimalists the burden of demonstrating that the total cost of judicial error in making case-specific decisions about rights outweighs the total cost of political error arising from judicial avoidance of such decisions.

The weaknesses in the durability argument fall into three categories. First, that argument underappreciates the capacity of the common law method to minimize the cost of judicial error. Second, it undervalues the cost of judicial failures to overturn erroneous political decisions in matters of rights. And third, it disregards the risk of erroneous judicial assessment of the risk of judicial error. I examine each weakness in turn.

\section{A. The Common Law Method, Adaptability, Judicial Error, and Rights}

As I argued in Part III.C.2, the common law method credibly produces claims of right in large part because of its gradualism, which supplies the element of continuity that seems bound up with the very notion of rights. But continuity is only one side of the gradualism coin; the other side is adaptability. Because common law decisionmaking proceeds on a fact-specific, case-by-case basis, the effects of one erroneous decision can be mitigated by limiting or avoiding its application to other cases.

Examples of this error-mitigation effect of common law gradualism are manifold in constitutional law, although for obvious reasons they tend not to be as prominent as examples of decisions with far-reaching precedential influence. Consider the Slaughter-House Cases, in which the Court narrowly construed the Privileges or Immunities Clause of the Fourteenth Amendment ${ }^{281}$ to protect from state infringement only rights of a distinctively national character, foreclosing an interpretation by which the Clause incorporates some or all of the first eight Amendments against the states. ${ }^{282}$ There are strong arguments that the Court's reduction of the Privileges or Immunities Clause to a "practical nullity"283 in Slaughter-House was an erroneous interpretation of the Constitution. ${ }^{284}$

281. "No State shall make or enforce any law which shall abridge the privileges or immunities of citizens of the United States . . . " U.S. Const. amend. XIV, $\$ 1$.

282. 83 U.S. (16 Wall.) 36, 74-80 (1873).

283. Edward S. Corwin, The Constitution of the United States of America: Analysis and Interpretation 965 (1953) (internal quotation marks omitted).

284. See, e.g., David P. Currie, The Constitution in the Supreme Court: Limitations on State Power, 1865-1873, 51 U. Chi. L. Rev. 329, 347-56 (1984) (arguing that Justice Miller's interpretation of Privileges or lmmunities Clause was contrary to intent of the 
Although Slaughter-House has never been overruled, its effect has itself been reduced to a practical nullity by the Court's gradual incorporation against the states of most of the first eight Amendments through the Fourteenth Amendment's Due Process Clause. ${ }^{285}$ The (arguable) constitutional error committed by the Court in Slaughter-House was mitigated over time by the Court's development of an alternative doctrine, Due Process Clause "incorporation," to compensate for that error.

1 it is true that minimalists like Sunstein and Dorf worry not only about the Court's ability to redress constitutional decisions that are erroneous when made, as Slaughter-House may have been, but also about the Court's ability to adapt to changing factual and moral circumstances-to revise decisions that have become erroneous, even if they were not necessarily erroneous ab initio. ${ }^{286}$ Some of the most celebrated decisions of constitutional law, however, have effected precisely such adaptations, changing doctrinal direction based upon the Court's recognition that factual backgrounds or moral understandings have changed. The Court's decision in West Coast Hotel Co. v. Parrish, for example, overruled Adkins v. Children's Hospital ${ }^{287}$ and repudiated the reasoning of Lochner $v$. New York ${ }^{288}$ largely on the basis of "recent economic experience" that had exposed the inadequacy of an unregulated market to redress the severe dis-

Framers); Howard Jay Graham, Our "Declaratory" Fourteenth Amendment, 7 Stan. L. Rev. 3, 24-38 (1954) (arguing that Justice Miller's interpretation ignored entire antislavery debate from 1834 on).

285. "No State shall . . . deprive any person of life, liberty, or property, without due process of law ...." U.S. Const. amend. XIV, § 1. See Chicago, Burlington \& Quincy R.R. v. Chicago, 166 U.S. 226, 241 (1897) (incorporating Fifth Amendment right to just compensation for takings of property); Fiske v. Kansas, 274 U.S. 380, 385-87 (1927) (incorporating First Amendment rights to free speech, press, and religion); Mapp v. Ohio, 367 U.S. 643, 655 (1961) (incorporating Fourth Amendment right to freedom from unreasonable searches and seizures); Robinson v. California, 370 U.S. 660, 666-67 (1962) (incorporating Eighth Amendment prohibition of cruel and unusual punishment); Gideon v. Wainwright, 372 U.S. 335, 342 (1963) (incorporating Sixth Amendment right to counsel); Malloy v. Hogan, 378 U.S. 1, 6 (1964) (incorporating Fifth Amendment privilege against self-incrimination); Pointer v. Texas, 380 U.S. 400, 403 (1965) (incorporating Sixth Amendment right to confront witnesses); Klopfer v. North Carolina, 386 U.S. 213, 222-23 (1967) (incorporating Sixth Amendment right to speedy and public trial); Washington v. Texas, 388 U.S. 14, 18-19 (1967) (incorporating Sixth Amendment right to compulsory process); Duncan v. Louisiana, 391 U.S. 145, 149 (1968) (incorporating Six th Amendment right to jury trial); Benton v. Maryland, 395 U.S. 784, 794 (1969) (incorporating Fifth Amendment prohibition of double jeopardy); Schilb v. Kuebel, 404 U.S. 357, 365 (1971) (incorporating Eighth Amendment prohibition of excessive bail).

286. See, e.g., Sunstein, One Case at a Time, supra note 8, at 174-75 (urging "judicial caution in invalidating regulatory controls" where "the relevant facts are . . changing very rapidly" or where "the legally relevant values are ... in flux"); Dorf, supra note 11 , at 26-50 (criticizing common law method for responding too slowly to changing circumstances).

287. 261 U.S. 525 (1923). Adkins itself had overruled Muller v. Oregon, 208 U.S. 412 (1908), on the grounds that "great ... changes ... have taken place since [Muller] in the contractual, political and civil status of women." Adkins, 261 U.S. at 553.

288. 198 U.S. 45 (1905) (invalidating New York law setting maximum hours for bakery employees). 
parity in bargaining power between low-wage employees and their employers. ${ }^{289}$ And the Court in Brown v. Board of Education, relying on the purported strength of contemporary social science research suggesting a connection between educational segregation and harmful psychological effects on children, ${ }^{290}$ effectively overruled Plessy $v$. Ferguson. ${ }^{291}$ The Brown Court expressly refused to "turn the clock back to . . . 1896 when [the Plessy opinion] was written" and "consider[ed] public education in the light of its full development and its present place in American life."292 Indeed, the Court has been explicit about its willingness to reconsider precedents when they have "been found unworkable," when they have become "doctrinal anachronism [s] discounted by society," or when their "premises of fact have so far changed ... as to render [their] . . . holding[s] somehow irrelevant or unjustifiable."293

One of the core arguments of the new minimalism, however, is that the common law method's capacity to perform long-term doctrinal adjustments has become insufficient in light of the apparently increasing pace of factual and moral change in our technologically driven and ideologically pluralistic society. As Michael Dorf writes, "life and law occur in the short run. Gradualist common law evolution takes place over the course of generations." ${ }^{294}$ On this version of the objection, the problem with constitutional adjudication is not so much durability as inertia.

One answer to this "inertia" version of the objection challenges the premise that adjustments in constitutional doctrine necessarily take place only in the long term. There are plenty of examples of cases in which the Court has corrected in the relatively short run what it believes to be its own constitutional errors. Take, for instance, the Court's overruling of Muller $v$. Oregon fifteen years later in Adkins, which was followed by its

289. West Coast Hotel Co. v. Parrish, 300 U.S. 379, 399 (1937) (upholding state law establishing minimum wage for women).

290. 347 U.S. 483,494 n.11 (1954).

291. 163 U.S. 537 (1896).

292. 347 U.S. at 492.

293. Planned Parenthood v. Casey, 505 U.S. 833, 855 (1992). The Casey Court cited West Coast Hotel and Brown as examples of cases in which changed circumstances justified the overruling of precedent. See id. at 861-64.

294. Dorf, supra note 11, at 45 (citation omitted). In conversation with me, Professor Dorf has expressed the tentative view that doctrinal stability might be more important in the context of constitutional rights than in other contexts, including statutory interpretation, with which Dorf is partly concerned in his Foreword. See id. at 5-7. As such, Dorf's critique of common law gradualism may not be intended primarily to address decisions involving individual constitutional rights. In his Foreword, however, Dorf is quite explicit about his view that the Supreme Court's constitutional rights methodology tracks the common law method he critiques: "The common law method, in the sense of case-bycase doctrinal development, plays an especially large role in the Court's constitutional rights jurisprudence." ld. at 29 (citation omitted). 1 think it is fair, then, to interpret Dorf's written critique of common law gradualism as applying to constitutional rights. Sunstein's advocacy of minimalism in areas of factual and moral "flux" is in the same vein. See Sunstein, One Case at a Time, supra note 8, at 174-75. 
overruling of Adkins fourteen years later in West Coast Hotel. ${ }^{295}$ Or consider the Court's overruling of National League of Cities $v$. Usery ${ }^{296}$ nine years later in Garcia v. San Antonio Metropolitan Transit Authority. ${ }^{297}$ As Richard Fallon acknowledges, "the Court not only can overrule its own precedents, but actually does so with some frequency." 298 Such examples of what Fallon calls "extraordinary adjudication" 299 illustrate that stare decisis in the Court's constitutional cases is at best a presumption, one that can be overcome when the Court decides the indicia of error are particularly strong. ${ }^{300}$

The Court also has shown its capacity to mitigate perceived constitutional errors in the relatively near term by means short of outright overruling. For example, in the quarter century since deciding Roe v. Wade, the Court has repeatedly refused to abandon Roe's "central holding" recognizing a constitutionally protected right to have an abortion, ${ }^{301}$ but at the same time it has adjusted the breadth of Roe enough to accommodate political experiments limiting the scope of that right. ${ }^{302}$

295. See supra note 287 and accompanying text.

296. 426 U.S. 833 (1976) (invalidating application of Fair Labor Standards Act to state government employers).

297. 469 U.S. 528, 546-47, 557 (1985).

298. Fallon, supra note 11, at 110 (citing Agostini v. Felton, 521 U.S. 203, 235 (1997) (overruling Aguilar v. Felton, 473 U.S. 402 (1985)) and Seminole Tribe v. Florida, 517 U.S. 44, 66 (1996) (overruling Pennyslvania v. Union Gas Co., 491 U.S. 1 (1989))).

299. See id. at $126-41$.

300. Michael Dorf has noted in conversation with me that some of these celebrated examples of short-term overrulings are perhaps better explained by political realities facing the Court (as in West Coast Hotel, which followed Roosevelt's court-packing threat and the so-called "switch in time that saved nine"), or by the change of heart of a single Justice (as with Justice Blackmun from National League of Cities to Garcia), than by the Court's goodfaith acknowledgment of prior error. A partial response to this observation is that the Court acts only through its members, and thus an overruling that is attributable to the conversion of a single Justice or to the replacement of old Justices with new ones is no less a recognition of error by the Court than a wholesale change of heart by a majority of the body would be. More fundamentally, the objection misses the point-which has to do with the Court's capacity for expeditiously changing course rather than with its motive for doing so. Decisions like West Coast Hotel and Garcia challenge the substantive minimalist premise that the Court (however motivated) cannot respond to its own constitutional errors as quickly as the political branches (however motivated) can respond to theirs. This is not to say that these decisions cannot be criticized based on the motivations behind them-only that they serve as examples which undermine the objection from inertia.

301. See, e.g., Planned Parenthood v. Casey, 505 U.S. 833, 860 (1992) (reaffirming $R o e$ 's “central holding[ ] that viability marks the earliest point at which the State's interest in fetal life is constitutionally adequate to justify a legislative ban on nontherapeutic abortions"); Webster v. Reproductive Health Servs., 492 U.S. 490, 521 (1989) (plurality opinion) (leaving "undisturbed" Roe's prohibition on state interference with abortion right prior to viability).

302. See, e.g., Planned Parenthood v. Danforth, 428 U.S. 52, 63 (1976) (upholding state statute defining "viability" "as "that stage of fetal development when the life of the unborn child may be continued indefinitely outside the womb by natural or artificial lifesupport systems' "); Maher v. Roe, 432 U.S. 464, 469-81 (1977) (upholding state regulation denying Medicaid benefits for nontherapeutic abortions); Harris v. McRae, 448 U.S. 297, 
Might there be some tension in extolling the connection between rights and the continuity of the common law method, as I did in Part III.C, while at the same time appealing to the adaptability of the common law method, as I have just done in responding to the inertia objection? In the context of overrulings of precedent, this tension may indeed exist. When the Court overrules its own precedent-at least when it does so in fairly short order, as in Adkins and West Coast Hotel-it acts like a legislature repealing a statute, and thus arguably forfeits some of its credibility as a trustworthy decisionmaker about rights. ${ }^{303}$ Of course, it can also be argued that the Court bolsters its credibility by quickly repudiating decisions that are obviously wrong. ${ }^{304}$

In the context, however, of mere limitations of precedent-the explicit distinction of prior decisions based on subtle factual differences, or even the kind of sub silentio distinction necessary to reconcile Romer $v$. Evans $^{305}$ with Bowers v. Hardwick ${ }^{306}$-any tension disappears. The common law method produces rights by analogy from prior decisions; if the Court can reasonably decline to draw such an analogy, then the "right" articulated in the prior case simply does not exist in the subsequent one (or, as in the Bowers-Romer dyad, the right articulated in the subsequent case simply was not precluded by the prior one). It is not as if the Court is creating a right and then denying or destroying it, as in the case of

326-27 (1980) (upholding federal "Hyde Amendment" prohibiting use of federal Medicaid funds to perform abortions other than those necessary to save life of mother or in cases of rape or incest); H.L. v. Matheson, 450 U.S. 398, 413 (1981) (upholding state statute requiring parental notice for abortions as applied to minors living with and dependent upon their parents); Planned Parenthood Ass'n v. Ashcroft, 462 U.S. 476, 490-93 (1983) (upholding state statute requiring parental consent for minors' abortions but providing alternative judicial consent procedures); Webster, 492 U.S. at 507-11 (upholding ban on performance of nontherapeutic abortions by state employees, or with the use of public facilities); Hodgson v. Minnesota, 497 U.S. 417, 423 (1990) (upholding state statute requiring parental notice and 48-hour waiting period for minors' abortions absent court order); Ohio v. Akron Ctr. for Reprod. Health, 497 U.S. 502, 506-07 (1990) (upholding state statute requiring parental notice and 24-hour waiting period for minors' abortions absent court order or fulfillment of certain other procedural requirements); Rust v. Sullivan, 500 U.S. 173, 203 (1991) (upholding prohibition on federal funding of abortion counseling and advocacy); Casey, 505 U.S. at 878-87 (rejecting Roe's trimester framework and upholding, under an "undue burden" standard, state requirements that physician inform woman of abortion risks and alternatives at least 24 hours prior to performing abortion, that parental or judicial consent be obtained for minors' abortions, and that certain recordkeeping and reporting functions be performed in connection with abortions).

303. This possibility underlies the connection drawn by the plurality in Casey between stare decisis and the "need for principled action [by the Court] to be perceived as such." 505 U.S. at 866.

304. This is a central message of the opinions of Chief Justice Rehnquist and Justice Scalia in Casey. See 505 U.S. at 944, 953-66 (Rehnquist, C.J., concurring in part and dissenting in part); 505 U.S. at 993-1002 (Scalia, J., concurring in part and dissenting in part).

305. 517 U.S. 620 (1996).

306. See Sunstein, One Case at a Time, supra note 8 , at 151-52. 
overruling. All the Court is doing is recognizing a limited, highly contextdependent right and then declining to extend its limits, or articulating a limited, highly context-dependent denial of a right and then declining to extend the limits of that denial. Continuity is not threatened by reasonably limiting rights to the contexts in which they were recognized. 1 is threatened, rather, by reneging on an existing commitment to recognize a right in a particular context.

So common law continuity and common law adaptability need not be incompatible. This point suggests a second answer to the inertia objection: The objection goes more to failures of procedural minimalism by the Court than to failures of substantive minimalism. Roe again serves as a good example. As Sunstein notes, Roe was an extremely wide opinion, famously statute-like (or even regulation-like) in its explicit application of the trimester framework to cases not before the Court. ${ }^{307}$ As 1 suggested above, the Court, for better or worse, has done a pretty decent job of trimming back these gratuitous elements of Roe. But the Court's ability to adapt would have been much greater if $R o e$ had been a much narrower opinion. The Roe Court could have invalidated the Texas law at issue in that case, which criminalized all abortions except those necessary to save the mother's life, ${ }^{308}$ without constructing the trimester guidelines that vexed the Court for the next two decades, and without broadly barring the states from acting on theories of when human life begins. A narrower decision would have left more room for the Court to accommodate, in future cases, advances in medical technology allowing both for safe abortions later in pregnancy and for the maintenance of fetal life outside the womb earlier in prenatal development. It also would have given the Court greater flexibility in allowing the political branches to determine, in the first instance, whether and how the abortion right should be applied in different factual contexts-abortions performed on minors, for instance, or abortions paid for with public funds. Although the Court succeeded remarkably quickly in removing many of these issues from the seemingly blunt impact of Roe, the failure of procedural minimalism in the Roe opinion did not make this task any easier.

In sum, when the Court adheres as closely as possible to procedural minimalism, it retains the ability to adapt rather quickly to changing circumstances and to mitigate rather quickly the effects of decisions that are erroneous from the start. A willingness by the Court to decide particular cases involving rights in areas of moral or factual "flux" or uncertainty

307. See id. at 17-18; see also, e.g., Archibald Cox, The Role of the Supreme Court in American Government 113-14 (1976) (the Roe opinion reads "like a set of hospital rules and regulations"); Webster, 492 U.S. at 518 (plurality opinion) ("[T]he rigid Roe framework is hardly consistent with the notion of a Constitution cast in general terms . . . [T] he result has been a web of legal rules that have become increasingly intricate, resembling a code of regulations rather than a body of constitutional doctrine."); cf. Sunstein, One Case at a Time, supra note 8 , at 54 (the Rne Court "laid down a set of rules for legislatures to follow whenever [the abortion] issue arose.").

308. See Roe v. Wade, 410 U.S. 113, 117-18 (1973). 
does not require such decisions to have broad effects, foreclosing adaptation and limitation in subsequent cases. Substantive nonminimalism does not undermine procedural minimalism, and procedural minimalism preserves doctrinal adaptability.

\section{B. The Costs of Substantive Minimalism}

The durability objection holds that judicial errors in matters of rights are likely to be harder to reverse or mitigate than political errors in such matters, and that the Court should thus be more reluctant to recognize rights (thereby removing the issue from the political process) than not to do so (thereby leaving the issue to the political process). The previous section suggested that the costs of erroneous judicial recognition of rights are not likely to be as great as the minimalists imagine. As I argue in this section, there is also reason to suspect that the costs of erroneous judicial failure to recognize rights may be greater than the minimalists acknowledge.

As an example, consider the evolution, if it can be called that, from Plessy v. Ferguson to Brown v. Board of Education. In Plessy, the Court refused to recognize a Fourteenth Amendment right to racially integrated accommodations on railroad trains. The Court's decision was quite wide in that it purported not merely to validate the particular law at issue, a Louisiana statute requiring "equal but separate accommodations" in railroad coaches, but to endorse all "[1] aws permitting, and even requiring, [the] separation [of the races] in places where they are liable to be brought into contact [with each other]." ${ }^{309}$ The Court's opinion even went so far as to mention expressly "the establishment of separate schools for white and colored children" as an example of a permissible law. ${ }^{310}$ The decision in Plessy also was quite deep in that it provided a relatively comprehensive theory of the Equal Protection Clause, ${ }^{311}$ declaring that the Clause "could not have been intended to abolish distinctions based upon color, or to enforce social, as distinguished from political equality," and categorically rejecting the argument that segregation statutes might violate the Clause by "stamp[ing] the colored race with a badge of inferiority." 312

The Court in Plessy declined to recognize an asserted constitutional right, thus leaving the issue of racial segregation to the political process. Moreover, the Court did so in a procedurally nonminimalist fashion, impairing the ability of future Courts to recognize the asserted right in other contexts. From the perspective of substantive minimalism, Plessy thus should be something of a holy grail: a decision leaving the maximum amount of decisionmaking authority to the political branches,

309. 163 U.S. 537, 540, 544 (1896) (internal quotation marks omitted).

310. Id. at 544 .

311. "No State shall ... deny to any person within its jurisdiction the equal protection of the laws." U.S. Const. amend. XIV, § I.

312. 163 U.S. at $544,551$. 
thereby greatly reducing the costs of judicial error. ${ }^{313}$ On the minimalist view, one would have expected the political process eventually to identify and correct Plessy's error without the need for subsequent Court intervention.

But of course the political process did no such thing. Fifty-eight years later, social and economic life in large parts of the country remained racially segregated by law, ${ }^{314}$ including segregation in contexts, like public education, in which it was much more socially significant than in the context of railroad transportation. Legislative change may never have come in the South; as recently as 1963, nine years after Brown, Governor George Wallace threatened to bar the doors of the University of Alabama to black students. ${ }^{315}$ And legislation did not arrive on the federal level until 1964, when the Civil Rights Act was adopted. ${ }^{316}$ The constitutional error ultimately was corrected not by the political branches, but by the Court itself in 1954, when it decided Brown.

313. The Plessy Court also could have chosen (but did not choose) to practice substantive minimalism in a second way: hy denying certiorari to hear the case, thus letting stand the Louisiana Supreme Court's decision upholding the constitutionality of the segregation statute. Substantive minimalism is the refusal to actually decide an issue squarely presented in a case out of deference to the decision of that issue reached by the political branches. It can take the form either of affirmatively approving, in a rubber-stamp fashion, the political branches' decision of the issue out of a reluctance to suhstitute judicial for political judgment, or of altogether avoiding passing judgment on the political branches' decision of the issue by, for instance, denying certiorari, thus exercising Bickel's "passive virtues."

Either of these choices-upholding the political judgment or simply letting it stand via the passive virtues-leaves the political branches free to later revise their decision of the issue if they desire. Both choices are "substantively" rather than "procedurally" minimalist because they entail refusal by the Court, out of deference to the political branches, actually to substitute its judgment for a political one. In contrast, a procedurally minimalist decision actually resolves the issue presented in a case, without special deference to the political resolution of that issue, but declines to resolve additional issues that are not necessary to the resolution of the case.

Note that the Court's motive for its decision matters to the question of whether that decision is substantively minimalist. If the Plessy Court upheld the Louisiana statute out of deference to the legislature-saying, in effect, "We defer to your judgment on this difficult constitutional issue" - then its decision was substantively minimalist. If, on the other hand, the Plessy Court upheld the statute because it independently agreed with the legislature's judgment regarding the application of the Equal Protection Clause on the facts of that case-saying, in effect, "ln this case our judgment happens to accord with yours, although we pay yours no special deference" - then it was not a substantively minimalist decision at all.

314. See generally Harvard Sitkoff, The Struggle for Black Equality, 1954-1992, at 3-36 (1993) (discussing the nature and impact of racial segregation in first half of twentieth century).

315. See id. at 145 (quoting Wallace: "I draw the line in the dust and toss down the gauntlet before the feet of tyranny, and 1 say, Segregation now! Segregation tomorrow! Segregation forever!").

316. Civil Rights Act of 1964, Pub. L. No. 88-352, 78 Stat. 243 (codified at 42 U.S.C. $\S 2000$ (1994)). 
Plessy, while procedurally nonminimalist, was substantively minimalist, although perhaps not consciously so. The Court in that case may have been "wary of recognizing rights . . . amid complex issues of fact and value," 317 or it may have been "aware that [the Court's] . . moral judgments, once announced, may not receive immediate social vindication and may instead produce something very different from what [the Court] intend[s]."318 Or the Court may simply have decided Plessy as it did because the majority thought it was interpreting the Constitution correctly. Whatever its motivation, from the perspective of substantive minimalism, Plessy should have reduced the costs of judicial error by deferring to the political branches. Instead it seems to have increased error costs by condemning two subsequent generations of Americans to live with unconstitutional segregation before Brown was decided-by "inflict[ing] unnecessary pain" for over half a century, in Mark Tushnet's words. ${ }^{319}$ The Court's erroneous decision not to recognize a right in Plessy proved to have its own inertia, and thus ended up producing its own quite severe error costs.

And suppose the political process had corrected Plessy's error within a generation or two, by repealing (or federally invalidating) Jim Crow and school segregation laws. In such an alternate universe, the costs of Plessy's error would have been no less severe than they actually were; unnecessary (and unconstitutional) pain still would have been inflicted upon countless innocents in the interim. Indeed, as Tushnet points out in a similar context, an 1896 Court decision strongly affirming a Fourteenth Amendment right against de jure racial segregation, viewed from a later perspective in which the political process has come around to the same view, "would seem to have been an act of statesmanship for which the Court deserves great credit." 320

To generalize the point: There is strong reason to believe that the costs of erroneous judicial failure to recognize constitutional rights can, and often will, be at least as severe as the costs of erroneous judicial recognition of constitutional rights. Constitutional rights, after all, are rights against the majority. What reason is there to think that the majority will change its mind before the Court does? If the majority does not do soand even if it does-what reason was there for the Court not to have gotten it right in the first place?

The new minimalists do not dispute-how could they?-that the Court must sometimes stand against the majority to articulate rights. ${ }^{321}$

317. Sunstein, One Case at a Time, supra note 8 , at 76 .

318. Id. at 103 .

319. Mark Tushnet, How to Deny a Constitutional Right: Reflections on the AssistedSuicide Cases, 1 Green Bag 2d 55, 60 (1997) (describing how a Court decision recognizing a constitutional right to assisted suicide might be assessed in ten years).

320. Id.

321. See, e.g., Sunstein, One Case at a Time, supra note 8 , at 38 ("[ I It is reasonable to think that Brown requires the [minimalist] thesis to be qualified, perhaps for the most 
Their contention is softer; they essentially argue that it usually is preferable for the majority, through politics, to reach correct decisions about rights by itself, rather than having decisions about rights imposed upon it by the Court. The key qualifier here is correct decisions. The longevity of legally mandated segregation after Plessy provides salient, if incomplete, evidence that the majority does not always arrive at the correct decision about rights without strong judicial intervention.

Perhaps more fundamentally, there is reason to question the distinction, implicit in substantive minimalism, between decisions made by the Court and decisions made by the majority. On an important level, the distinction certainly exists; the Court's constitutional decisions sometimes, and necessarily, go against the wishes of a then-prevailing majority. But the Plessy-Brown progression suggests a more complex long-term relationship between the Court's constitutional decisionmaking and majority values. A willing Court could have limited Plessy early and often, by refusing, for example, to apply the Plessy dictum regarding school segregation in cases actually involving education. ${ }^{322}$ That the Court declined to limit Plessy in this way suggests, to me at least, that most of the Justices shared the then-prevailing social view that segregation, at least in schools, was neither immoral nor constitutionally forbidden. ${ }^{323}$ ln other words, the supposedly countermajoritarian Court was, in a very real sense, acquiescing in the majority's view about constitutional rights. ${ }^{324}$

Whether this kind of de facto adherence to majority opinion is appropriate is in my view largely irrelevant, because it is inevitable, to some

compelling cases where the underlying judgment of (constitutionally relevant) political morality is insistent."). Again, abolitionists like Tushnet apparently do not share this view. See supra note 248 and accompanying text.

322. The Court had at least two early chances to decline to apply Plessy in the context of education, but it took neither of them. See Cumming v. Board of Educ., 175 U.S. 528 (1899) (upholding a local tax assessment used to support a whites-only public high school); Berea College v. Kentucky, 211 U.S. 45 (1908) (upholding a criminal statute prohibiting the operation of integrated private schools).

323. As late as $1950,52 \%$ of respondents in a Life magazine poll supported continued school segregation either in the South or nationwide. Forty-one percent supported nationwide integration, and 7\% did not answer or were undecided. Rick Bragg, Ora and Her Wonder School, Life, Sept. 1999, at 49, 58 (reprinting results of 1950 poll).

324. Tushnet, citing the mid-century work of political scientist Robert Dahl, contends that over the long run the Court has rarely if ever been successful in persisting with constitutional doctrine that runs counter to majority values. See Tushnet, Taking the Constitution Away, supra note 7, at 134 ("According to Dahl, the Supreme Court rarely holds out for an extended period against a sustained national political majority." (citing Dahl, supra note 107, at 285)). Of course, there is something of a chicken-and-egg problem lurking here: The fact that the Court often seems eventually to "change its mind" and conform to majority values does not mean that the majority never "changes its mind" in conformity to, or at least partly in response to, decisions of the Court. Indeed, Brown, and its eventual vindication in, inter alia, the 1964 Civil Rights Act, may be an example of this latter type of conformity. Nevertheless, I have no qualms about conceding Tushnet's point that over the long run the Court sometimes, even often, conforms its constitutional decisionmaking to majority values, at least to some degree. 
degree at least. Supreme Court Justices are members of society, albeit privileged ones, and it is impossible for them completely to escape the tug of prevailing social values. ${ }^{325}$ Nor is it clear that we would want the Justices to do so if they could. As Richard Fallon suggests,

[W] hen interpreting the Constitution ... the Court appropriately acts in a representative capacity. ... The relevant question for the Justices is ... how the Constitution ought to be interpreted and implemented in light of history and of the diverse, more or less intense, and possibly fluid array of reasonable moral views within the society. ${ }^{326}$

As such, the Court appropriately might answer questions about the existence and scope of a constitutional right partly by reference to the presence, absence, or strength of social consensus about the right, or indeed by reference to the level of certainty within the Court itself about the right's validity.

There is, however, a crucial difference between this sort of approach and substantive minimalism. On a nonminimalist approach, the Court might take factors like social consensus and judicial uncertainty into account in deciding whether or in what form a constitutional right exists. But on a minimalist approach, the Court uses such factors as reasons not to decide whether or in what form a right exists-as reasons, that is, to leave such decisions in the hands of the political branches, either by rubber-stamping a political decision or by avoiding review of it. To the extent it is able-a key qualifier, as 1 explain in the next section-the Court might legitimately consider social and epistemological factors in making decisions about rights. But it is much harder to argue that the Court should consider such factors in refusing to make decisions about rights at all.

\section{The Inescapable Problem of Judicial Fallibility}

The durability argument for substantive minimalism does not hold that the fact of judicial fallibility always counsels deference to the judgments of the political branches. It holds only that the Court should take judicial fallibility into account in deciding whether to afford such deference. On the new minimalist account, the potential for judicial error is particularly great where society as a whole is divided on a question. Thus, for Sunstein, "[ $t]$ he case for minimalism is especially strong when the area involves a highly contentious question now receiving sustained dem-

325. Indeed, it is unlikely that the Court would remain a viable institution of government if, over the long run, it were not profoundly influenced by majority values. At bottom, the Court's power exists at the sufferance of the other branches; Congress and the President can restrict its jurisdiction, change its composition, or, as a matter of realpolitik, simply ignore its decisions. As John Rawls has written, " $[t]$ he constitution is not what the Court says it is. Rather, it is what the people acting constitutionally through the other branches eventually allow the Court to say it is." John Rawls, The Idea of Public Reason, in Deliberative Democracy: Essays on Reason and Politics, supra note 215, at 93, 112.

326. Fallon, supra note 11 , at 144 . 
ocratic attention. In such areas, courts should be aware that even if they rely on their own deepest convictions, they may make mistakes . . ."327

In order to determine whether, or how much, the Court should defer to the political branches, the Court must assess the likelihood that it will err-an assessment that may require a suhsidiary analysis of the degree of public controversy surrounding the issue. Presumably there will be some point at which the Court will conclude that the risk of error is too great and consequently will defer to the political branches. Prior to that point, the Court will conclude that the risk of error is not great enough to justify such deference.$^{328}$ As Joshua Sarnoff has put it in a different context, substantive minimalism thus assumes a "tipping point of confidence in judgment," on one side of which the Court will defer and on the other side of which the Court will decide. ${ }^{329}$

And herein lies a fairly serious analytical problem with substantive minimalism. For in order to make an assessment of the likelihood of judicial error, the Court must risk judicial error. In order to determine whether an issue is so fraught with moral or factual uncertainty that the Court should not decide it, the Court must make a judgment that itself is fraught with moral or factual uncertainty. The decision not to decide is still a decision. By deciding not to decide an issue on grounds of moral or factual uncertainty or dispute, the Court is not solving the problem of moral or factual uncertainty; it is simply transposing that problem to a different plane. Instead of making a (morally or factually fallible) decision of the issue itself, the Court is making a (morally or factually fallible) decision about whether to decide the issue.

Worse, interjecting the question of social controversy-or the related question of the political consequences of a Court decision-into the larger question of whether to defer to the political branches does more than simply shift the locus of potential judicial error. It asks the Court to make exactly those types of decisions that minimalism assumes the Court should avoid. As Mark Tushnet writes, "If minimalism is to guide decision, the justices must make essentially political judgments. They are to ask themselves, What is the current state of public discussion of the issue, and-if public discussion is on-going-what decision will have the least impact on that discussion?" 330 But assessments of the state of public discussion and the impact of a judicial decision on that discussion inevitably will involve the same kinds of "complex issues of fact and value" that minimalists assert the Court should avoid deciding. ${ }^{331}$ Thus, as Tushnet

327. Sunstein, One Case at a Time, supra note 8 , at 59 .

328. As an example, Sunstein defends the result in Brown v. Board of Education, which was substantively nonminimalist, on the grounds that "the underlying judgment of (constitutionally relevant) political morality [wa]s insistent" in that case. Id. at 38.

329. Joshua D. Sarnoff, Equality as Uncertainty, 84 Iowa L. Rev. 377, 403 (1999).

330. Tushnet, supra note 319 , at 59 .

331. Sunstein, One Case at a Time, supra note 8 , at 76 . 
points out, "minimalism calls on judges to make precisely those judgments that its premises assert judges should not make." ${ }^{332}$

The juricentric approach suggests there may be good reasons for judges to avoid making these judgments, reasons beyond Tushnet's concern that "[a]s a general matter, the American people do not expect justices to be making political judgments on this level." 333 Complex calculations of the state of public discussion about an issue and of the probable effects of Court "intervention" ${ }^{34}$ are bound to be polycentric problems in Fuller's sense; they are unlikely to be amenable to the kind of principled decisionmaking that the Court is good at. ${ }^{335}$ As such, at least in cases involving rights, a Court decision not to decide an issue because of the risk of judicial error or unintended consequences seems more likely to be erroneous than a Court decision of the issue itself.

To the extent it relies on judicial fallibility, then, the argument for substantive minimalism either proves too much or it proves nothing at all. It proves too much if it holds that the Court should never override the political branches' decisions, an extreme to which few of the new minimalists would willingly go. But it proves nothing at all if it acknowledges that the Court should override the political branches in some cases but not others, because there is no infallible way for a fallible Court to distinguish permissible decisions from impermissible ones.

\section{CONCLUSION}

Assessments of judicial review typically suffer from policentrism: They assume the Court should play a role subordinate to the political branches, and then they defend or attack judicial review on the basis of its success or failure in preserving that subordination. The new movement toward judicial minimalism, led by Sunstein, is no exception to this general rule. Unlike the work of Alexander Bickel that it evokes, the new minimalism demands judicial restraint as a means of permitting as many decisions as possible to be made politically and of increasing the extent to which those political decisions are deliberative and accountable.

I have suggested in this Article that the policentrism of the new judicial minimalism is largely misguided. Policentrism rests on the twin assumptions that judicial decisionmaking is significantly less democratically legitimate than political decisionmaking, and that it has no significant advantage over political decisionmaking in the area of individual rights.

332. Tushnet, supra note 319 , at 60 .

333. Id.

334. As Tushnet notes, "[n]on-intervention is a form of intervention too, in the sense that it allows the discussion to continue against a background set of [existing] laws ... that themselves allocate costs." Id. at 59.

335. See supra Part III.C.3; cf. Gerald Gunther, The Subtle Vices of the "Passive Virtues"-A Comment on Principle and Expediency in Judicial Review, 64 Colum. L. Rev. 1,5 (1964) (criticizing Bickel for advocating "polluting the [judicial] decisional process through excessive preoccupation with the political market place"). 
Each of these assumptions is vulnerable. Adjudication, even constitutional adjudication, is a form of meaningfully participatory decisionmaking that binds through interest representation. Its participatory and representative elements give adjudication a strong measure of democratic legitimacy. Moreover, the judiciary generally is better suited than the political branches to make decisions involving individual rights-partly because of the judiciary's well-known insulation from majoritarian politics, partly because of the opacity of its decisionmaking procedures, and perhaps above all because of the gradualism and particularism of the common law method that it employs.

The juricentric picture of the judiciary-at its pinnacle, the Supreme Court-as a democratically legitimate and uniquely competent branch of government undermines the premises of the new judicial minimalism. On the juricentric view, there is little or no good reason for the Court regularly to defer to the political branches on matters of rights. But the juricentric view itself provides a different set of reasons for one manifestation of minimalism-what I have called procedural minimalism, the practice of deciding that which is necessary to resolve a case but no more. Some degree of procedural minimalism is essential to preserving the ties of interest representation between precedent-setting litigants and subsequent litigants or conforming nonlitigants, and thus to preserving the legitimacy of binding those subsequent parties. Procedural minimalism also is essential to sustaining the unique advantage enjoyed by the Court over the political branches in decisions involving individual rights, an advantage that depends in large part upon the gradualism and particularism that typically characterize the Court's decisionmaking process.

At the same time, the juricentric view calls into question what 1 have called substantive minimalism, the practice of deferring to the political branches in decisions involving rights for fear of judicial error. The juricentric view suggests that a Court adhering to procedural minimalism can mitigate its own errors and adapt to changing circumstances more effectively than the new minimalists suppose. lndeed, it suggests that the Court sometimes, perhaps often, can overcome its own constitutional errors faster and with less cost than the political branches can overcome theirs. And it highlights the incoherence of requiring the Court to make potentially costly fallible judgments about when to avoid making potentially costly fallible judgments.

Before concluding this Article, I should disclaim any attempt to prove more than I want to prove. 1 do not want to argue that all manifestations of what might be called substantive minimalism are invalid for the reasons discussed above. To be sure, there are aspects of the Court's accepted practice that can be viewed as expressions of substantive minimalism: the Court's preference for avoiding unnecessary decision of constitutional issues; the presumption of constitutionality the Court applies; doctrinal tests like "rational basis" review which require the Court to defer to political decisions in contexts not involving strong indicia of rights 
violations. ${ }^{336}$ Taken to a logical extreme, my arguments here might he read to suggest that these well-pedigreed manifestations of judicial deference are analytically flawed and should be abandoned.

In my view, however, these conventions are best understood not as techniques of substantive judicial minimalism, but rather as simple obstacles to changing the status quo where doing so would have significant costs (much like the garden-variety burdens of proof imposed on plaintiffs and prosecutors), or else as rules requiring default to political decisionmaking in cases of substantial evidentiary doubt, or perhaps as combinations of both. Even if viewed as aspects of substantive minimalism, norms that simply hold "when in doubt, defer" do not go as far as the new minimalists suggest the Court should go in deferring to the political branches. The new minimalists ask the Court to defer not only in cases of judicial doubt, but sometimes in cases of relative judicial confidencecases where the Justices' "own deepest convictions" counsel invalidation of a political decision, even cases in which "the Court's resolution [is] right, in the sense that the Court identifies the just result." ${ }^{337}$ If such cases "involve[ ] . . highly contentious question[s] now receiving sustained democratic attention," or the strong possibility that "unintended adverse consequences" might follow from the Court's (otherwise correct) decision, the new minimalism counsels deference. ${ }^{338}$

It is this strong form of substantive minimalism that $I$ have challenged in this Article. Nothing I have written here is intended to question the validity of judicial norms against changing the status quo, or of deferring to political decisions in the face of genuine judicial uncertainty, or of identifying and defining rights partly by reference to the extent of deep social agreement about their existence and scope. What 1 have tried to challenge is the policentric premise of the new judicial minimalism and one of its prescriptive consequences: that the Court, like a shrinking violet, should habitually bow to the supposedly superior legitimacy and competence of the political branches in matters of rights. The Court's role, to which it is uniquely suited, is precisely to make such decisions.

336. See Fallon, supra note 11, at 88-90 (discussing "rational basis" and other "nonsuspect-content" tests).

337. Sunstein, One Case at a Time, supra note 8 , at 59 .

338. Id. 